\title{
RELACAĀO ENTRE RELEVO E SOLOS PROVENIENTES DE ROCHAS ERUPTIVAS BÁSICAS
}

MARIA DE FÁTIMA GUIMARÄES

orientador: Dr. Octavio Freire

Dissertaçāo opresentoda a Escolo de / Agricultura Luiz Queiroz, da Universidode de $S \bar{o}$ Poulo, para obtencão do titulo de Mestre em Agronomio-área de concentraçōo: Solos e Nutriçōo de plontos.

PIRACICABA

Estodo de Sōo Poulo-Brasil

Maio- 1984 
a Oswaldo e Maria Thereza

a Luiza, Lourdes e Celina

a Maria Salete, José Oswaldo José Eduardo 
AGRADECINENTO ESPECIAI

à Dra. Wolmar Apparecida Carvalho, pela dedicação e a poio no início da carreira científica e na elabora ção deste trabalho. 


\section{AGARDECIMENTOS}

- ao Dr. Octávio Freire pela orientação e pela amiza de ;

- ao colega M Sc Edison Miglioranza, pela ajuda indispensável na análise morfológica dos solos;

- ao Dr. Geraldo Victorino de França pela revisão des te trabalho;

- aos colegas e amigos Amador Villacorta Mosqueira, Christian H. Roth, Gilvan Wosiacki, Blancaluz Pinilla Carvajal e Silvio José Bicudo pela ajuda e incentivo;

- à Francisco Carlos de Andrade, pela elaboração dos mapas ;

- ao Instituto Brasileiro do Café pelo empréstimo das fotografias aéreas;

- à Fundação Instituto Agronômico do Paranā pelas análises químicas e granulométricas do solo e pelo fornecimento dos dados termopluviométricos;

- ao CNPq pela concessão da bolsa de estudo;

- à CAPES pela concessão da Bolsa Deslocamento conce dida através do PICD/UEL;

- a todos que de uma forma ou de outra ajudaram na e laboração deste trabalho. 

pretação e Reconhecimento de Solos .......

2.2. Características do Padrão de Drenagem e da Evolução do Relevo Relacionado a So -

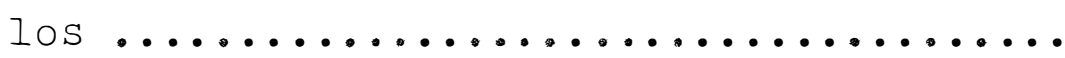

2.3. Integral Hipsométrica e Integral Volumétri ca $\ldots \ldots \ldots \ldots \ldots \ldots \ldots \ldots \ldots \ldots \ldots \ldots$

3.1.2. Dados de temperatura e precipita-

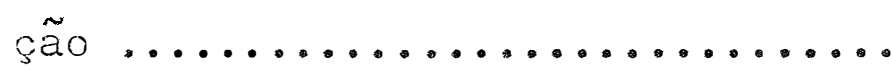

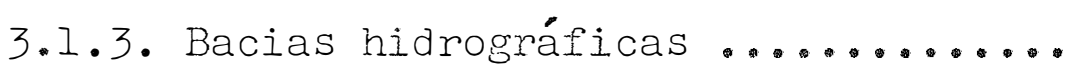

3.1.4. Carta topográficas e mapa geológi-

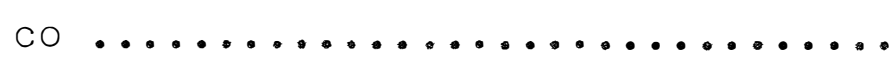


3.2.2. Obtenção do balanço hídrico ........

3.2.3. Obtenção do mapa de drenagem ....... 22

3.2.4. Seleção das bacias hidrográficas .... 23

3.2.5. Análise das características do

padrão de drenagem ............ 24

3.2.6. Aspectos do relevo ............. 26

3.2.6.1. Obtenção dos mapas pla-

co-hipsométricos das bacias

3.2.6.2. Razão de relevo, integral

hipsométrica, integral vo-

lumétrica e relação de ma-

terial erodido $\ldots \ldots \ldots$.....

$2 \cdot 6$

3.2.7. Determinações de campo ........... 28

3.2.8. Determinações de laboratório ....... 29

4. RESULTADOS $\ldots \ldots \ldots \ldots \ldots \ldots \ldots \ldots \ldots \ldots \ldots \ldots \ldots \ldots \ldots \ldots \ldots$

4.1. Dados Climáticos ................... 31

4.2. Características das Bacias Hidrográficas ... 31

4.2.1. Análise dimensional e semelhança

geométrica .................. 32

4.2.2. Características do padrão de dre-

nagem $\ldots \ldots \ldots \ldots \ldots \ldots \ldots \ldots \ldots . . \ldots \ldots$

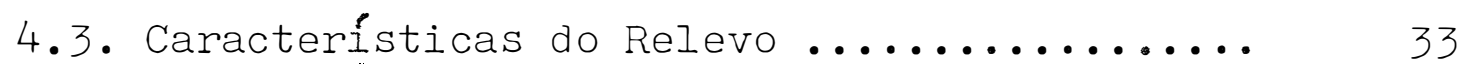

4.3.1. Razão de relevo ............... 33 
4.3.2. Integrais hipsométricas e volumétricas ..................... 34

4.4. Características Morfológicas, Granulométricas e Químicas dos Solos Estudados ..... 34 4.4.1. Descrição morfológica ........... 34 4.4.2. Análise granulométrica e química ... 34

5. DISCUSSÃO DOS RESULTADOS ............... 75

5.1. Dados Climáticos .................. 75

5.2. Características das Bacias Hidrográficas .. 76 5.2.1. Análise dimensional e semelhança

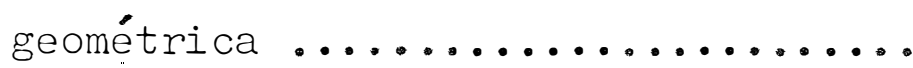

5.2.2. Características do padrão de dre nagem $\ldots \ldots \ldots \ldots \ldots \ldots \ldots \ldots$

5.3. Características do Relevo ............. 81

5.3.1. Razão de relevo .............. 81

5.3.2. Integrais hipsométricas e volumé-

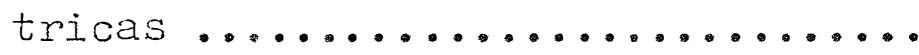

5.4. Características Moriológicas, Granulométricas e Químicas dos Solos Estudados ..... 87 5.4.1. Latossolo Roxo ................ 87 5.4.2. Terra Roxa Estruturada .......... 88 5.4.3. Litossolo fase substrato basaltito $\ldots \ldots \ldots \ldots \ldots \ldots \ldots \ldots \ldots \ldots$ 
Página

6. CONCLUSÕES $\ldots \ldots \ldots \ldots \ldots \ldots \ldots \ldots \ldots \ldots \ldots \ldots . \ldots \ldots$

7. BIBLIOGRAFIA CITADA .................... 94 


\section{LISTA DE TABELAS}

Tabela no

Página

1 Parâmetros para a Classificação da Textura Topográfica com Base nos Valores da Ra zão de Textura Média ................. 25

2. Resultados Numéricos do Balanço Hídrico Segundo Thornthwaith (1955), Referente à. Localidade de Bandeirantes. Período: 1974

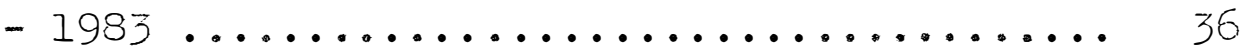

3 Propriedades Dimensionais das Bacias Hidrográficas Representativas dos Solos Es-

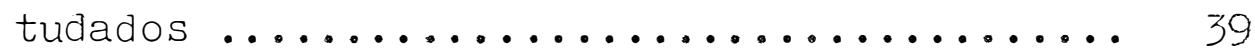

4 Análise Diemnsional e Semelhança Geométri ca, Aplicadas às Bacias Hidrográficas Representativas das Areas Estudadas ......... 40

5 Número e Comprimento de Segmentos de Rios em cada Ordem de Ramificação e Total para as Bacias Hidrográficas Representativas dos

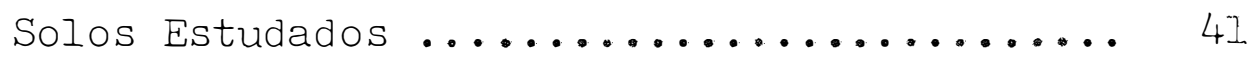


6 Caracteristicas Quantitativas dos Padröes de Drenagem e as Classes de Textura Topográfica das Bacias Hidrográficas Repre sentativas das Unidades de Solo Estudadas...

7 Dados Médios de Frequência de Rios (F), Drendade de Drenagem (Dd), Razão de Tes $\operatorname{tura}(\mathrm{T})$, Razão de Textura Média (Tm) e Classe de Textura Topográfica Obtidos pa-

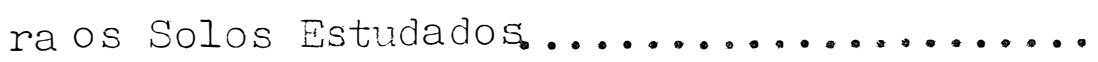

8 Relações Funcionais entre Parâmetros que Definem as Características dos Padrões de. Drenagem Obtidas para as Unidades de Solo; Coeficiente de Correlação $(r)$; Coeficiente de Determinação $\left(r^{\hat{2}}\right)$; Teste $t$ para b (tb) e Teste $F$ para a Regressão .......... 44

9 Características do Relevo das Bacias Hidrográficas Representativas dos Solos Es-

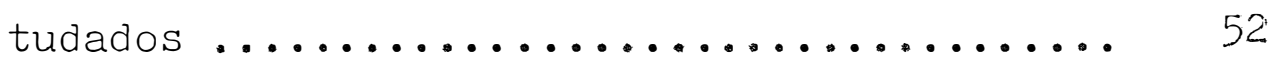


Integral Hipsométrica e Integral Volumé trica referentes à Bacia Hidrográfica I, Representativa da Unidade Latossolo Ro-

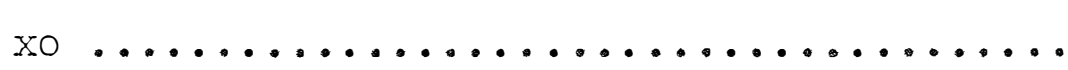

11 Integral Hipsométrica e Integral Volumé trica Referentes à Bacia Hidrográfica II, Representativa da Unidade Latossolo Roxo $\ldots \ldots \ldots \ldots \ldots \ldots \ldots \ldots \ldots \ldots \ldots \ldots$

12. Integral Hipsométrica e Integral Volumé trica Referentes à Bacia Hidrográfica III, Representativa da Unidade Latosso-

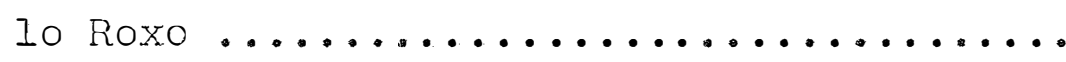

13 Integral Hipsométrica e Integral Volumé trica Referentes à Bacia Hidrográficia I, Representativa da Unidade Terra Roxa ES

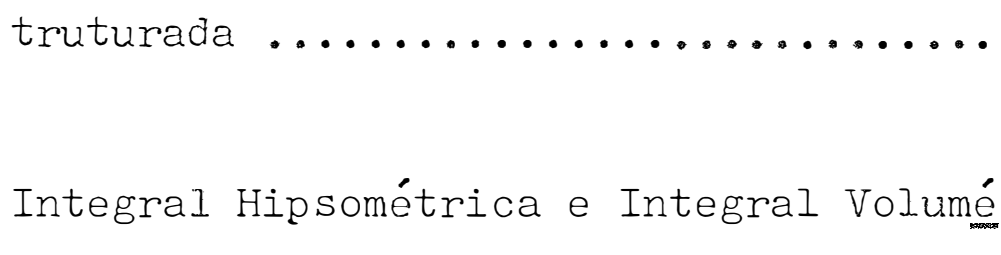
trica Referentes à Bacia Hidrográfica II, Representativa da Unidade Terra Ro-

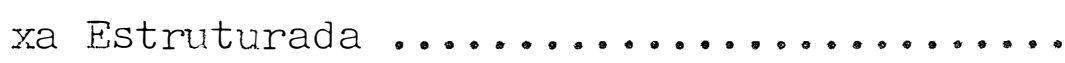


Integral Hipsométrica e Integral Volumé trica Referentes à Bacia Hidrográfica III, Representativa da Unidade Terra Roxa Estruturada

Integral Hipsométrica e Integral Volumé trica Referentes à Bacia Hidrográfica I, Representativa da Unidade Litossolo fase substrato basaltito $\ldots \ldots \ldots \ldots \ldots \ldots$

17 Integral Hipsométrica e Integral Volumé trica Referentes à Bacia Hidrográfica II, Representativa da Unidade Litossolo fase substrato basaltito ..........

18 Integral Hipsométrica e Integral Volumé trica Referentes à Bacia Hidrográfica III, Representativa da Unidade Litos solo fase substrato basaltito ..........

Valores Hipsométricos Obtidos para as Bacias Hidrográficas Representativas dos Solos Estudados...................... 
20 Descrição Morfológica dos Perfis Repre sentativos da Unidade Latossolo Roxo $(\mathrm{LR}) \ldots \ldots \ldots \ldots \ldots \ldots \ldots \ldots \ldots \ldots \ldots \ldots \ldots \ldots \ldots \ldots \ldots \ldots$

2'l Descrição Morfológica dos Perfis Repre sentativos da Unidade Terra Roxa Estru turada $(\mathrm{TE}) \ldots \ldots \ldots \ldots \ldots \ldots \ldots \ldots \ldots \ldots \ldots \ldots \ldots$

¿2 Descrição Morfológica dos Perfis Repre sentativos da Unidade Litossolo fase

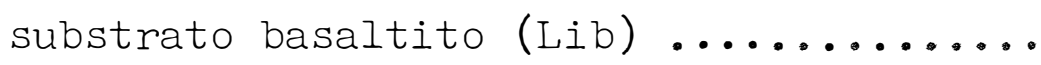

23 Resultados da Análise Granulométrica das Perfis de Latossolo Roxo (LR) Contidos

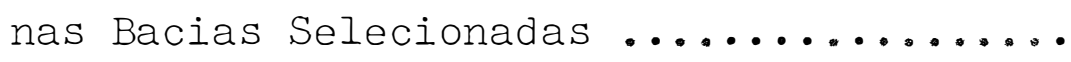

24 Resultados da Análise Granulométrica dos Perfis de Terra Roxa Estruturada (TE) Contidos nas Bacias Selecionadas ........

25 Resultados da Análise Granulométrica dos Perfis de Litossolo fase substrato basal tito Contidos nas Bacias Selecionadas .... 
26 Resultados da Análise Química do Complexo Trocavel dos Perfis de LatossoIo Roxo (LR) Contidos nas Bacias Sele

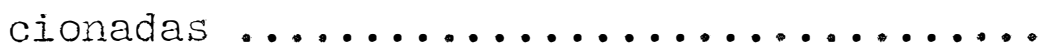

27 Resultados da Análise Química do Complexo Trocavel dos Perfis de Terra Ro xa Estruturada (TE) Contidos nas Ba-

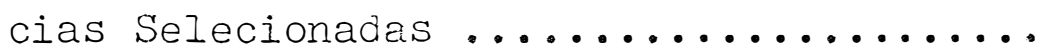

Resultados da Análise Química do Complexo Trocavel dos Perfis de Litossolo fase substrato basaltito (iub) Con tidos nas Bacias Selecionadas ........ 


\section{LISTA DE FIGURAS}

Figura $n^{0}$

Página

1 Localização da Area Estudada no Estado

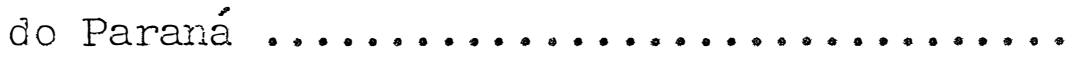

2 Representação Gráfica do Balanço Hídri co Segundo Thornthwaithe (1955), Referente à Localidade de Bandeirantes. Pe ríodo de $1974-1983$.................

3 Rede de Drenagem e Bacias Hidrográficas de 3a Ordem de Ramificação da Area Estudada ....................... 38

4. Bacia Hidrográfica I Representativa da

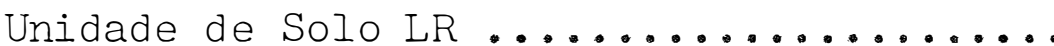

5 Bacia Hidrográfica II Representativa da Unidade de Solo LR ................ 46

6 Bacia Hidrográfica III Representativa

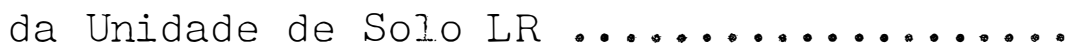


7 Bacia Hidrográfica I Representativa da Unidade de Solo IE ................... 48

8 Bacia Hidrográfica II Representativa

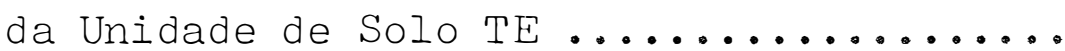

9 Bacia Hidrográfica III Representativa

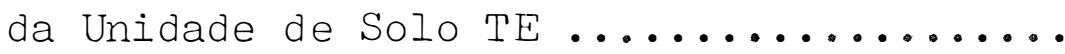

10 Bacias Hidrográficas Representativas da

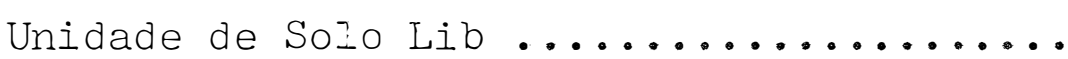

11 Integrais Hipsométricas e Volumétricas Representativas da Unidade Latossolo Ro $x \circ \ldots \ldots \ldots \ldots \ldots \ldots \ldots \ldots \ldots \ldots \ldots \ldots \ldots \ldots \ldots \ldots \ldots \ldots$

12 Integrais Hipsométricas e Volumétricas Representativas da Unidade Terra Roxa

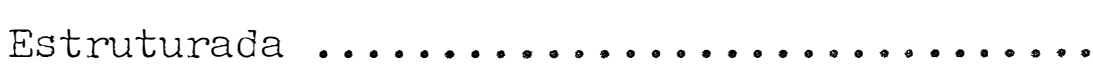

13 Integrais Hipsométricas e Volumétricas Representativas da Unidade Litossolo $\underline{\text { Ia }}$

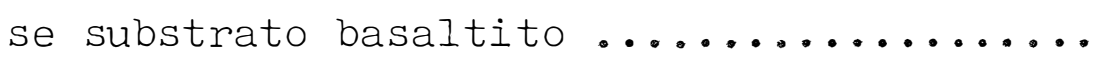


RESUMO

Com o intuito de se avaliar o estágio de evo Iução de solos provenientes da decomposição de rochas erupti vas básicas e o estágio de desenvolvimento do relevo foram a plicados métodos fotointerpretativos em bacias de $3^{\underline{a}}$ ordem de ramificação e efetuadas descrição morfológica, análises de rotina em laboratório e análise hipsométrica em três unidades de solo situadas no nordeste do Estado do Paraná: Latossolo Roxo, Terra Roxa Estruturada e Litossolo fase substrato basaltito.

A metodologia utilizada e os dados obtidos no presente trabalho permitiram as seguintes conclusões:

a) a frequência de rios, a densidade de drena gem, a razão de textura e a razão de textu ra média mostraram-se eficientes na distin ção entre os solos, apresentando valoresde 
crescentesna seguinte sequência: Litossolo fase substrato basaltito $>$ Terra Roxa Estruturada $>$ Latosso Roxo;

b) a classe de textura topográfica não permitiu a distinção entre Terra Roxa Estrutura da e Litossolo fase substrato basaltito;

c) a razão de relevo foi significativa para indicar diferenças de drenagem entre as unidades de solo, sendo seus valores decres centes na seguinte sequência: Litossolo fa se substrato basaltito $>$ Terra Roxa Estru turada > Latosso Roxo;

d) a descrição morfológica, as análises quími cas e granulométricas dos solos associadas à análise hipsométrica permitern afirmar gue os solos encontram-se num estágio de evolu ção que obedece à sequência: Latossolo Roxo $>$ Terra Roxa Estrutura $>$ Litossolo fa se substrato basaltito; enquanto que o relevo da unidade Latossolo Roxo encontra-se num estágio de maturidade em comparação às unidades Terra Roxa Estruturada e Iitossolo fase substrato basaltito que se encontram num estágio de maturidade tendendo pa 
ra a velhice. 
A method of photointerpretation of third order hydrological basic was used with the aim to study the stage of evolution of soils originated from eruptive basic rocks and the stage of relief formation. This was complemented by the morphological description, routine laboratory analysis and hipsometric analysis of the three occuring soil units, comprising Latossolo Roxo, Terra Roxa Estruturada and Litosso lo, basaltic substratum phase, located in the northeastempart of Paraná state.

The methods used and the results obtained in this work allowed the following conclusions:

a) the frequency of rivers, the drainage density, the textural ratio and the medium tex tural ratio were shown to be efficient in distinguishing the soil types, whereby values decreased in the following ordes: Litossolo, basaltic substratum phase $>$ Terra 
Roxa Estruturada > Latossolo Roxo;

b) the topographical texture class did not permit a distinction between Terra Roxa ES truturada and Litossolo, basaltic substratum phase;

c) the relief ratio was significant to indicate diferences in drainage between the soil units, the values decreasing in the follow ing ordes: Litossolo, basaltic substratum phase > Terra Roxa Estruturada > Latossolo Roxo;

d) the morphological description, the chemical and granulometrical analysis of the soils associated with the hipsometrical analysis, showed that the stage of evolution of the studied sols has the following seguence: La tossolo Roxo $>$ Terra Roxa Estruturada $>$ Litossolo, basaltic substratum phase. Thereby the relief of the unit Latossolo Roxo is found to be in the state of maturity men compared to Terra Roxa Estruturada and Litossolo, basaltic substratum phase, the la tter two being in a state of maturity but tending to a state of old age. 
I. INTRODUCS̃̃O

Coube a Bushnell, em 1926, a primazia de utilizar fotografias aéreas em levantamentos de solos. A partir desta data tem-se notícia do uso crescente das fotografias aé reas em trabalhos de levantamento de solos, uma vez que elas propiciam a observação estereoscópica da paisagem e constituem uma fonte adicional de informações.

No Brasil, a fotointerpretação de solos teve İ nício com França, em 1968, e a partir de então foram desenvolvidos muitos trabalhos de correlação entre solos e aspectos da paisagem, como a rede de drenagem e o relevo.

A interpretação de imagens da paisagem e dosso los depende dos conhecimentos de pedologia do fotointérprete, uma vez que apenas a superfície do solo é visível, sendo que algumas vezes pode estar mascarada pela cobertura vegetal. A fotointerpretação do relevo e da rede de dre nagem está correlacionada com a relação entre infiltração e 
deflúvio dos solos. Assim, solos profundos apresentando estmitura porosa possuem alta relação e ocorrem em relevos estáveis, em equilíbrio com o ambiente, enquanto que solos jovens ocorrem em paisagens instáveis, onde a erosão tem influência predominante na ocorrência de solos pouco desenvolvidos.

Neste trabalho pretende-se aplicar técnicas de fotointerpretação a três importantes unidades de solo provenientes de rochas eruptivas básicas, ocorrentes no nordeste do Estado do Paraná, com o objetivo de avaliar o estágio de evolução dos solos através da descrição morfológica, análises química e granulométrica, bem como o estágio de desenvolvimen to do relevo através de índices do padrão de drenagem e análi ses hipsométricas, em bacias de 3ạ ordem de ramificação. 
2. REVISÃO DA BIBIIIOGRAFIA

2.1. Importância da Fotografiia Aérea na Interoretação e. Reconhecimento de Solos.

De acordo com COLWELL (1952), fotointerpratação é o ato de examinar imagens fotográficas de objetos, visando identificá-los e avaliá-los. A fotointerpretação é baseada no princípio de convergência de evidências, segundo o qual, se vários elementos de reconhecimento conduzem a uma determinada conclusão, a possibilidade desta ser correta é muito grande.

Segundo Simonson (1950), citado por RAY (1963), a utilização de fotografias aéreas foi um dos maiores avanços, nas décadas de 30 e 40, em levantamentos de solos. Para SUIMERSON (1954), interpretação é a previsão do que rãa pode ser visto realmente. Desta forma, esta definição é perfeita para fotointerpretação de solos; visto 
que, além de na fotografia não aparecer o perfil do solo,mas somente a sua superfície, este geralmente está coberto pela vegetação. No entanto, outros aspectos do terreno como formas topográficas, padrões e características de drenagem, vegetação, erosão, uso e tonalidade fotográfica podem indicara ocorrência de solos diferentes.

Para Schultz e Cleaves (RAY 1963), a forma fi. siográfica é o elemento de maior importância na fotointerpre tação de solos, uma vez que está baseadä nas afinidades entre aspectos geomorfológicos e solos.

Segundo LUEDER (1959), depois da forma fisiográfica tem grande importância a rede de drenagem superficial. No entanto, adverte que é necessário muita experiência para interpretar-se corretamente a significância ò padrão cie are nagem.

RABBEN (1960), RAY (1963) e RICCI e PETRE (1965) consideram a fotointerpretação como um processo em duas etapas. Na primeira etapa são Ieitas as observações, coletas de dados, identificação de aspectos reọistrados e medições. Na etapa seguinte, caz-se a interpretação propriamente dita.Por este processo, FRANĢA (1968) obteve sucesso na avaliação da significânja das característices da rede de drenagem na diferenciação de solos na região de Piracicaba. Da mesma manei ra, MARCHETI (1969) conseguiu estabelecer diferenças entre solos, baseando-se nas características das redes de drenagem e do relevo. No eritanto, outros elementos fornecem informa- 
mações igualmente importantes como, por exemplo, a erosão.

GOOSEN (1968) relata sobre a interpretação de fotografias aéreas e sua importância enr levantamento de solos.

É inegavel a grande quantidade de informações que se pode obter através da fotografia aérea. No entanto, esta técnica não dispensa o trabalho de campo e tem importân cia maior nos levantamentos de reconhecimento, segundo afirmam, dentre outros, BURINGH (I960) e GOOSEN (1968).

Para FROST (1960) a fotointerpretação de soIos consta de três princípios básicos: 1 - solos semelhantes apresentain padrão semęhante; 2 - solos direrentes apresentarn padrão diferente; 3 - correlacionando-se as características da imagem fotográfica com propriedades do solo observadas no campo e no laboratório, propriedades de solos semeIharites poder ser inferidas através da fotointerpretação.

Dentre as várias maneiras de se obter informa ções quantitativas, uma das principais é a fotografia aérea, devido à riqueza de detalhes que contém, muitos deles dimensionaveis (RAY e FISCHER, 1960).

Para HOWE (1960) a fotografia tem grande importância no estudo de águas superficial e subterrânea. Dentre as aplicações estão: estudo dos padrões de drenagem superficial, composição de mapas básicos de drenagem e avaliação do potencial hidrográfico de uma bacia. Da mesma forma, ZINKE (1960) demonstra a utilidade da fotointerpretação em 
estudos de hidrologia e manejo de bacias hidrográficas.

\subsection{Características do Padrão de Drenagem e da Evolução do Relevo Relacionado a Solos.}

A rede de drenagem como um todo, obtida atra vés da fotografia aérea, tem permitido correlações particula rizadas com os solos ocorrentes. Os primeiros estudos tinham bases descritivas e já revelavam que as redes de drenagem refletiam características dos materiais em que os solos se desenvolviam.

HORTON (1945), ao estudar os processos erosivos, responsaveis pelo desenvolvimento de sistemas hidrográficos e suas bacias de drenagem, concluiu que, para um certo ambiente, os processos de erosão hídrica dependem primeira. mente da proporção entre infiıtração e deflúvio, existindo um comprimento mínimo de escoamento sobre a superfície, para ca da terreno, necessário para acumular um volume de deflúvio ca paz de iniciar a formação de canais. Concluiu ainda que esse "comprimento crítico" depende do declive da superfícje, da capacidade de infiltração, da velocidade de deflúvio e da re sistência do solo à erosão. Porém, este autor considera a re sistência do solo à erosão, como o fator de maior importância à longo prazo. Para expressar o grau de desenvolvimento da drenagem superficial de uma bacia hidrográfica, propọs duas relações: densidade de drenagem e frequência de rios. 
De acordo com RAY (1963), a resistência à erosão diminui à medida que a densidade de drenagem aumenta, pois, pare um certo ambiente climático, a densidade de drena gem tem relação com è resistência à erosão dos materiais que ai ocorrem.

HORTON (1945) e STRAHLER (1957) concluíram não serem diretamente comparaveis a densidade de drenagem e a fre quência de rios entre pequenas e grandes bacias, uma vez que seu.s valores variam com c tamanho da área de drenagen.

De acordo com STRAHLER (1957), somente bacias de mesma ordem de ramifficação podem ser comparadas para a ob tenção de resultados significativos.

SMITH (1950) propôs um írdice, ao qual denomi nou razão de textura, para expressar o espaçamento entre canais de drenagen em mapas topográficos com curvas de nivel. U ma vez que os mapas topográficos geralmente não representem os canais de drenagem menores e que, no entanto, as crênulas ou irflexões das curvas de nível indicam a presença de canais de drenagem, nesse caso recomenda a escolha da curva de nئvel de maior rúmero de inflexões e que seja dividido o número de crênulas dessa curva pelo perímetro da bacia, obtendose assim a razão de tes.tura.

Por outro lado, HOWE (1960), RAY (1963), RICCI e PETRI (1965) e FRANÇA (1968) preconizam o uso de magens básicos de drenagem obtidos através de exame estereoscópico de fotografias aéreas para determinação da textura topográfi 
ca, usando-se o número total de rios da bacia ao invés do nú mero de inflexões da curva de nível.

SMITH (1950) propôs e FRANÇA (1968) modificou a determinação da razão de textura média, a fim de eliminar o efeito da área.

Os valores de densidade de drenagem (Dd) são geralmente bem menores nos solos com horizonte B latossólico, guando confrontados com solos com horizonte B textural. Para LUEDER (1959), isto é proveriente de uma alta relação entre infiltração $e$ deflúvio ros solos com $\mathrm{B}$ latossólico, devido à maior profundidade e, consequentemente, menor influência do substrato, relevo de ocorrência geralmente mais suave, homogeneidade textural ao longo do perfil e presença de microagre gados estaveis.

Segundo CARVALHO (1977), c comprimento total de rios analisado isoladamente não possibilita a diferenciação hidrológica das unidades de solo: Terra Roxa Estruturada e Podzólico Vermelho Amarelo variação Piracicaba, no entanto quando relacionado com a área (densidade de drenagem) mostrau se eficiente.

FRANÇA (1968) encontrou para o Latossolo Roxo - valor de 0,99 para Dd, GEVAERD (1976) encontrou 1,25 e ESPINDOLA e GARCIA (1978) obtiveram 1,06. Por outro lado, para a Terra Roxa Estruturada foi encontrado, por GEVAERD (1976), - valor de 6,32 para Dd, enquanto que CARVALH (1977) obteve 0,77 . 
Estes dados comprovam as afirmações de LUEDER (1959); entretanto CARVALHO (1977) justifica o baixo valorde Dd devido à grande profundidade dos perfis, forte grau de es truturação, relevo suave, alta permeabilidade e alta resistência à erosão.

A frequência de rios apresenta valores cuja distribuição é muito parecida com a Dd. Pará o Latossolo Roxo FRANÇA (1968) encontrou valores de 0,78 3,44 para Fr, en quanto que GEVAERD (1976) obteve valores de 1,I7 a 2,44 e ES PINDOLA e GARCIA (1978) o valor de 1,43. Para a Terra froxa Estruturada os valores de Fr encontrados foram de 4, 31 a 5,35 por GEVAERD (1976) e de 1,83 por CARVALHO (1977).

GEVAERD (1976), trabalhando com Brunizem Avermelhado, encontrou valores de 1,79 para Da e de 5,69 a 11,62 pare Fr.

Segundo RANzANI (1969), o relevo da superfície do solo pode ser identificado em termos de diferenças de altitude podendo ser referido como as desi.gualdades de forma da superfície. (O mesmo autor afirma que a conformação do ter reno representa um componente de grande importância, uma vez que condiciona as drenagens intema e externa do solo.

CARVALHO (1981), estudando a relação entre o grau de evolução do relevo e dos solos encontrou valores de razão de relevo de 0,047 para solos com B latossólico e 0,1234 para Solos Litólicos. 
2.3. IntegraI Hipsométrica e Integral Volumétrica

Aplicações geomorfológicas da análise hipsomé trica segundo STRAHIIR (I952), enfatizando os estágios de ma turidade do relevo através da interpretação das formas das curvas hipsométricas e do valor de suas integrais, define os estágios de juventude, maturidade e senilidade. A juventudé caracterizada por apresentar desequilíbrio, onde a sedimenta ção é menor que a erosão e a curva representativa desse está gio assume forma concava na parte superior e convexa nas par tes central e final. A maturidade se caracteriza por apresen tar equilíbrio entre a sedimentação e a erosão, a curva da integral hipsométrica passa pela parte central do diagrama e assume forma côncava na primeira metade e convexa na segunda. Na senilidade, caracterizada por ser um estágio temporário, pois os ciclos são dinâmicos e a erosão pode recomeçar, as curvas apresentam forte convexidade e valores baixos da inte gral; no entanto, querdo a erosão recomeçar a curva voltaráa assumir, no diagrama, posições mais elevadas.

De acordo com CHORLEY E MORLEY (I959), O dimensionamento volumétrico de bacias hidrográficas tem relação direta com a hidrologia e, geomorfologicamente, a integral hipsométrica expressa, quantitativamente, o rebaixamento ero sivo da bacia hidrográfica.

Na atuação dos processos morfogenéticos, VIEI RA (1978) considera que existem muitos pontos de semelhança 
entre as bacias hidrográficas e voçorocas. Este autor utilizou índices e conceitos propostos na bibliografia para o estudo das bacias hidrográficas e para estudos morfométricos de voçorocas localizadas em Franca (SP).

Segundo STRAHIER (1952), características dos canais de cabeceira, tais como: gradiente, comprimento e for ma dos declives, propriedades hipsométricas e densidade de drenagem, são de grarde utilidade para comparar regiõos, segundo suas semejhanças ou diferenças.

Na fotointerpretação de solos, destaca-se o aspecto erosivo como elemento Iígado à drenagem. Esse aspecto foi estudado amplamente na Iiteratira, destacando-se BELCHER (1942), IUEDER (1959), BURTINGH (1960) e GOOSEN (1968), que consideram os sulcos de erosão e a drenagem superficial como sendo os aspectos erosivos mais importantes vare a roto interpretação de solos.

Para as nossas coridiços, a principal causa do desgaste e empobrecimento dos solos, originada pela nem sempre orientada retirada da cobertura vegetal e uso e manejo i nadequado dos solos, é a erosão hídrica (ERENZEL, 1980).

Segundo STRAHIER (1952́), bacicàs hidrográficas de $3 \underline{a}$ ou 4a ordem de ramificação que apresentam relevo acica tado e alta densidade de drenagem tendem a apresentar integrais hipsométricas relativamente baixas; no entanto, no relevo suave, em estágio de maturidade, apresentando gradiente de rios suaves e baixa densidade de drenagem, resultam inte- 
grais relativamente al.tas.

A. estudar bacias de 3 ạ ordem de ramificação de Latossolo Roxo e Prunizem Avermelhado, GEVAERD (1976) encontrou valores de integrais hipsométricas mais altos para estes últimos.

Segundo PENTEADO (1974), a ação do relevo tem influência na dinâmica da água nos perfis e, isto propicia di ferenciação dos solos na "catena". Para ESPINDOLA (1977), existe influência dos solos sobre a evolução do relevo.

Entretanto, para RUFIIAN (1971) a evolução dos solos está estreitamente ligada à evolução do relevo e ambos influenciam-se mutuamente.

Segundo PENTEADO (1968), os solos reproduzem um fragil equilíbrio entre relevo, clima e vegetação; no entanto para GREENE (1945), nas regiões tropicias as condições topográficas assumem papel mais importante que os movimertos da água no perfil.

De acordo com ROBINSON et alii. (1961), quando um dos fatores de formação de solos domina rum determinado lo cal, esta influência é caracterizada de maneira tal que os solos maduros vão ocorrer em declives suavemente ondulados a ondulados, enquanto que em situações mais acidentadas a erosão se encarrega de remover o material formado e os solos per manecem jovens.

Segundo VAN WAMBECK (1962) a estrutura do so- 
lo, dentre outros parâmetros morfológicos, pode ser utilizada para avaliar os diferentes estágios de alteração do solo, sendo que nos bem evoluídos é normalmente constituída por poros muito finos e agregados miúdos, com ausência de cerosi dade; enquanto que nos solos jovens os agregados são poliédri cos, apresentando cerosidade.

Para ESPINDOLA (1977), a estabilidade da fração argìla e o estágio geomórfico senil da paisagem contri buem para o amadurecimento do solo e, aliada a essas caracte rísticas, a profundidade do solo pode ser tomada como indício de maturidade.

A relação entre silte e argila, para VAN WAMBECK (1967), pode ser indicativa do estágio de evolução dos solos. Assim, teores relativamente altos de silte, em relação à fração argila, indicam que o sol.o é jovem.

Conforme CARVALHO et alii. (1977), c modelamen to da superfície é função do processo erosivo nela instalado e a caracterização da erosão de uma área é função dos solos, do relevo e da rede de drenagem.

NTa evolução dos solos, o relevo tem influência muito mais marcante do que a idade do material de origem e modi ficações climáticas (TERCINIER e QUANTIN, 1968).

Foi estabelecido por BRASIL (1960), uma cronossequência de solos na qual o litossolo evolui para solo com B textural e este para solo com B latossólico. Entretanto, ESPINDCLA e GALHEGO (1979) admitem que nas superfícies 
de erosão antigas e aplainadas predominam solos com B latossólico e que os solos com B textural e litossolos aparecem nas vertentes; do que se presume que são resultantes do enta Ihamento daquela superfície antiga de solos com B latossólico, com exposição de material recente e rochas retrabalhadas. No entanto, um litossolo não significa necessariamente um solo no início de formação, podendo, devido à situação atual do relevo, ser o produto da remoção de cama das de solo formadas, já que não há condições de acúmulo do material, conforme MARCOS e KINJO (1967).

Segundo BRASIL (1960), devido à ação da erosão em antigas superfícies de latossolos, podem originar -se solos de várias naturezas, como por exemplo, os litossolos, onde os altos teores de silte indicam um estágio juvenil. Nes ses perfis rejuvenescidos, GAMBLE e DANIELS (1964) encontraram elevados valores de saturação de bases, indicando menor grau de alteração.

PIEDADE (1980), estudando comparativamente a evolução de bacias hidrográficas contendo voçorocas em duas áreas do município de Botucatu (SP), caracterizadas por Regossol "intergrade" para Latossol Vermelho-Amarelo e "intergrade" para Podzólico Vermelho-Amarelo (RPV + RLV) e Latosso lo Vermelho-Amarelo fase arenosa (LVa), encontrou menores va lores da relação de material erodido para a unidade LVa, :e justificou como sendo devido à imposição geológica e ao rele vo suavemente ondulado, indicando que, em relação à unidade 
$\mathrm{RPV}+\mathrm{RLV}$, menores quantidades de sedimentos estão sendo transportadas para fora das bacias de 3 a ordem de ramifica ção. Para a unidade RPV + RLV foram obtidos maiores valores da relação de material erodido, associados à maior profundidade do manto de intemperismo, confirmando à presença de for mas mais severas de erosão. Concluiu, também, a partir do vâ lor médio da integral hipsométrica, juntamente com a forma da curva no diagrama, que a área de RPV + RLV encontra-se no es tágio mais jovem de relevo (retomada de erosão), o que foi confirmado pela presença de testemunhos de erosão; enquanto que a área de LVa se encontra num relevo mais maduro.

CARVALHO et alii. (I983), estudando treze bacias hidrográficas do município de Botucatu (SP) com o objetivo de comparar o relevo e o material erodido das bacias, en contraram que as bacias hidrográficas com predominância de Latossolo Vermelho-Amarelo fase arenosa, com maiores razãode relevo e relação de material erodido, se encontram num está gio mais jovem de desenvolvimento do relevo, comparativamente às unidades Latossolo Vermelho-Amarelo e Latossolo Roxo, que apresentam tendência à maturidade. 
3. MATERIAL. E MÉTODO.

\subsection{Material}

\subsubsection{Area estudada}

A área estudada está localizada nos municípios de Santa Mariana, Leópolis e Cornélio Procópio - Paraná e está representada na Figura 1. Essa área está compreendida peIos meridianos de 5048'09" e de 5026'38" de longitude W Gr. e entre os paralelos de 23001'42" e de 23009'54" de latitude $\mathrm{S}$, abrangendo uma superficie de $1615,93 \mathrm{lsm} \mathrm{km}^{2}$.

- Estado do Paraná é parte integrante do Planalto Meridional Brasileiro. Segundo MAACK (1968), esse Estado compreende cinco regiões fisiográficas: Litoral, Serra do Mar, Primeiro Planalto ou Planazto de Curitiba, Segundo Planalto ou Planalto de Ponta Grossa e Terceiro Planalto ou Plam nalto de Cruarapuava. A área estudada está Iocalizada no Ter- 
ceiro planalto. A morfologia da paisagem dessa região é carac terizada pelas fomais de mesetas e pelas formas levemente on-duladas, com chapadas de encostas suaves.

Ceologicamente, a área do Terceiro Planalto é relativamente uriforme e caracterizada pela presença de extexsos lençóis de lava de origem vuicânica, que constituem o "Trapp" do Paraná, e de exposições de arenito.

Segundo BRASIL(1971) e observações de campo, a área estudada é constituída essencialmente de rochas erupti-

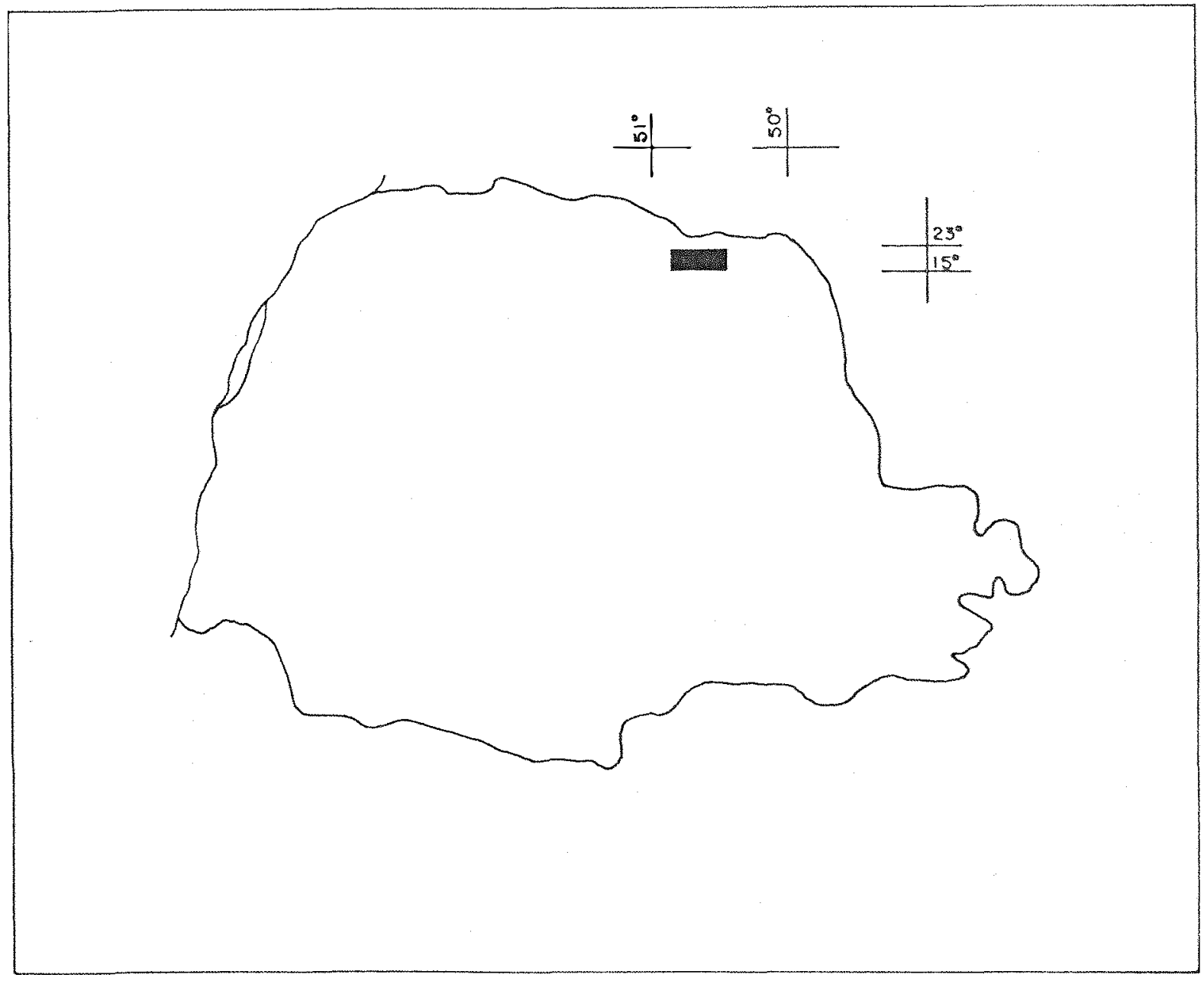

Fig. I Locolizopōo do Áreo Estudado no Estado do Paraná. 
vas básicas da Formação Serra Geral.

Para a realização do trabalho foram escolhidas três unidades de solo provenientes do mesmo material de origem, porém apresentando diferenças na permeabilidade e na re lação entre infiltração e deflúcio: apresentando, portanto, também diferenças no comportamento hidrológico e desenvolvimento de redes de drenagem superficial. Essas unidades foram classificadas por BRASIL (1971) como Latossolo Roxo, Terra Ro xa Estruturada e Litossolo fase substrato basaltito.

A primeira unidade é constituída de solos mui to profundos, argilosos, de coloração arroxeada, com sequência de horizontes A, B e C, presença de B latossólico; são muito porosos e acentuadamente drenados, ocorrendo em relevo suavemente ondulado, apresentando alta resistência à erosão, fertilidade moderada e alta retenção de água.

A segunda unidade é constituída de solos profundos, argilosos, de coloração arroxeada, com sequência de horizontes A, B e C,presença de B textural; são porosos e bem drenados, ocorrendo em relevo ondulado, apresentando alta re sistência à erosão, alta retenção de água e alta fertilidade.

A terceira unidade é constituída de solos argilosos pouco desenvolvidos, com sequência de horizontes A"e $R$ ou $A,(B)$ e $R$, de coloração vermelho escuro acizentado, ocor rendo em relevo fortemente ondulado e montanhoso. São rasos, porosos, bem drenados e de elevada fertilidade.

A vegetação predominante nas duas primeiras u 
nidades é floresta tropical subpererifólia, cujos exemplares mais comurn são: peroba (Aspidosperma sp.), canafístula (casSia fastuosa), cedro (Cedrela fissilis, Vell.), guaritá (Fagara rhoifolia, Engel), figueira branca (Ficus organensis, Miguel) e outras. A vegetação que predomina na terceira unidade é floresta tropical subcaducifólia, exuberante com presença de palmáceas, epífitas e outras (BRASII, 1971).

Conforme a classificação de Kßpper, o clima da região é do tipo Cfa - mesotérmico úmido, subtropical de transição com verões quertes, apresentando o trimestre mais chuvoso ros meses de dezembro, janeiro e fevereiro e o mais seco compreeridendo os meses de jurho, julho e agosto, sem es tação seca definida e geadas severas pouco frequentes.

\subsubsection{Dados de temperatura e precipitação}

Os dados climáticos da região foram obtidos a través do Instituto Agrorômico do Paraná (Area de Climatologia) para as coordenadas de 23006' latitude S, lorgitude 500 21. W Gr. e altitude de $440 \mathrm{~m}$, compreendendo o período de $1977-1983$.

\subsubsection{Bacias hidrográficas}

Foram utilizadas fotografias aéreas verticais procedertes da cobertura aerofotogramétrica do Estado do Paraná efetuada em 1970, na escala nominal aproximada de 
I:25.000, constando das faixas 93A, 94A e 95A. O recobrimento longitudinal entre as fotografias está em torno de $60 \%$ (faixa de vôo) e o recobrimento lateral está em tomo de 30\% (fai xas adjacertes); permitindo, portanto, visão esteroscópica. As fotografias aéreas foram utilizadas para a composição do mapa básico de dreragem da área e delimitação dos divisores de água das bacias de terceira orden. Para a localização das fotos que cobriam a á rea em estudo, foi utilizado um fotoíndice na escala de $1: 100.000$.

\subsubsection{Cartas topográficas e mapa geológico}

Para maior facilidade de localização dos nomes dos acidentes físicos da área, foram utilizadas cartas to pográficas (IBGE - Carta do Brasil, folha SF-Ziz-V-I-2, 1963 e folha SF-ziz-V-II-I, 1970), na escala 1:50.000, com curvas de nível equidistantes de 20 metros.

Para os estudos hipsométricos das bacias hidrográficas foram utilizadas as mesmas cartas topográficas, interpolando-se curvas de nível de $10 \mathrm{em} 10 \mathrm{~m}$.

o recorhecimerito geológico preliminar da área foi feito através do Mapa Geológico do Estado do Paraná, na escala 1:750.000 (MAACK, 1953).

\subsubsection{Equipamento}

Para as observações estereoscópicas dos pares 
de fotografias aéreas foram utilizados um estereoscópio de bolso Vasconcelos e um estereoscópio de espelhos WIID modelo ST 4.

A transferêricia das linhas de contorno das ba cias hidrográficas (divisores de água), do mapa básico de drenagem para a carta topográfica na escala de 1:50.000 foi efetuada com o auxílio de um "aero-sketchmaster" Zeiss, mode Io Luz.

Também foram utilizados: curvímetro marca Der by, escala triangular, compasso de ponta seca e planímetro po lar marca OTT.

\subsection{Niétodo}

3.2̇.1. Escolha da área de estudo

Procedeu-se à escolha de uma área com três unidades de mapeamento proveniertes de material de origem semelhante, mas situadas em relevos distintos.

A área foi delimitada com auxílio dos mapas de solo disponíveis, fotoíndices e cartas topográficas; tendo si do, então, identificadas as fotografias aéreas que cobriam a região de estudo.

3.2.2. Obtenção do balanço hídrico

o balanço hídrico foi elaborado a partir de 
dados da Estação Metereológica de Bandeirantes, Estado do Pạ raná, por ser a mais próxima e por identificar melhor o clima da área estudada. O período analisado foi de apenas 7 anos; pois, os dados disporíveis eram referentes ao períodode $1.977-1.983$.

Pelo método de THORNTHWAT'E (1955), foi calcu lado o balanço hídrico a partir de dados de precipaitação e tem peratura, considerando-se a capacidade de retenção de água no solo como sendo de $125 \mathrm{~mm}$.

3.2.3. Obtenção do mapa de drenagem

De acordo com o método proposto por RABBEN (1960), primeiramente procedeu-se à separação da área útil das fotografias aéreas. Através do exame estereoscópico, foram decalcadas de fotografias aéreas, em papel "cronaflex", a rede de drenagem e o divisor de águas de bacias de zạ ordem. No traçado da rede de drenagem, foram considerados os canais de drenagem permanentes e temporários, conforme STRAHLFR (1957) e LUEDER (1959).

Através dos decalques efetuados na área útil de cada fotografia, foi montado o mapa da rede de drenagem.

Os diferentes compartimentos da paisagem foram definidos a partir do exame de fotografias aéreas e cartas topográficas e confirmados em incursões ao campo, sendo os seus contomos transferidos para o mapa da rede de drena- 
gem, os quais serviram de limite das unidades de solo.

\subsubsection{Seleção das bacias hidrográficas}

Foram utilizadas bacias hidrográficas de zậ프 dem de ramificação, por sua eficiência no estudo de solos e formações superficiais, como foi comprovado por FRANÇA(1968), CARVAiHO (1977) e PIEDADE (1980).

Para cada unidade de solo foi aplicado o teste de semelhança geométrica proposto por STRAHLER (1957)e mo dificado por FRANÇA (1968) com o propósito de obterem-se dados mais seguros para a escolha das três bacias representati vas para cada unidade de solo. Para a apli.cação do teste, foram utilizados os seguintes parâmetros:

- maior comprimento (C) medido com compasso de ponta seca e mais escala, acompanhando aproximadamente a direção do vale principal, entre a foz e o ponto extremo na linha do divisor de águas;

- maior largura (L) - medida com compasso de ponta seca e escala, na maior largura medida transversalmente ao vale principal;

- comprimento do rio principal (CP) - medido com curvímetro ao longo docurao principal, da foz até a nascen te, acompanhando as sinuosidades, segundo o sistema de Horton;

- comprimento total da rede (CR) - medido com curvímetro, compreendendo a soma dos comprimentos do rio prin 
cipal e seus tributários, considerando as sinuosidades;

- perímetro (P) - medido com curvímetro, acom parhando a linha do divisor de águas que circunda a bacia;

- área (A) - medida com planímetro, compreendendo área circunscrita pela linha do divisor de águas que circunda a bacia.

3.2.5. Análise das características do padrão de drenagem

Foram analisados todos os canais de drenagem, quer possuam cursos d'água temporários ou permanentes, de acordo com as características quantitativas do padrão de drenagem, preconizadas na bibliografia, tais como:

- frequência de rios (F) - é a relação entre - número total de rios da bacia e sua respectiva área (HoRTON, 1945);

- densidade de drenagem (Dd) - é a relação en tre o comprimerto total de rios da bacia e sua respectiva area (HORTON, 1945);

- razão de textura (T) - é a relação entre o número total de rios da bacia e seu respectivo perímetro (SIMTTH, 1950; modificada por FRANCA, 1968);

- razão de textura média $(T m)$ - expressa pela média ponderada em relação às áreas das respectivas bacias, modificada por FRANÇA (1968), obtida pela fórmula: 


$$
\mathrm{Tm}=\frac{\sum(\mathrm{A} \cdot \mathrm{T})}{\sum \mathrm{A}} ; \text { onde: }
$$

Tm é a razão de textura média,

A representa a área das bacias em $\mathrm{km}^{2}$ e

I indica a razão de textura de cada bacia hi drográfica;

- textura topográfica - baseada nos valores de textura média, calculada segundo os parâmetros propostos por SMITH (1950) e adaptadas ao sistema métrico por FRANÇA (1968), cujos valores estão apresentados na Tabela 1.

TABELA 1 - Parâmetros para a Classificação da Textura Topográfica com Base nos Valores da Razão de Textura Média.

\begin{tabular}{|c|c|c|}
\hline \multirow{2}{*}{$\begin{array}{l}\text { Classe de Textu } \\
\text { ra Topográfica }\end{array}$} & \multicolumn{2}{|c|}{ Razão de Textura Mèdia } \\
\hline & $\begin{array}{l}\text { Perímetro expres } \\
\text { so em milhas }\end{array}$ & $\begin{array}{l}\text { Perímetro expres } \\
\text { so em quilome- } \\
\text { tros }\end{array}$ \\
\hline grosseira & $\angle 4$ & $<2,5$ \\
\hline média & 4 a 10 & 2,5 a 6,2 \\
\hline fina & $>10$ & $>6,2$ \\
\hline
\end{tabular}

Foram efetuados estudos comparativos entre as características do padrão de drenagem através de regressões do tipo $\mathrm{y}=\mathrm{a}+\mathrm{bx}$, onde y assumiu os valores da frequência de rios (F) e da razão de Textura $(T)$ e $x$, os valores da den 
sidade de drenagem ( $D d$ ) e frequência de rios ( $F$ ), nas seguin tes correlaçöes: $F \times D d ; T \times D d$ e $T$ X F para cada área estudada.

\subsubsection{Aspectos do relevo}

3.2.6.1. Obtenção dos mapas olaco-hipsométricos das bacias

De posse do mapa de drenagem da área e das cartas topográficas, foram elaborados os mapas placo-hipsomé tricos das bacias hidrográficas de 3 a ordem da área estudada. A utilização do "aero-sketchmaster" possibili tou a transferência das curvas de nível da carta placo-hipso métrica para o mapa de drenagem, sendo que, posteriormente, foi feita a interpolação de curvas de nível; resultando na repre sentação das bacias na escala de 1:2́5.000, com curvas equidis tantes de $10 \mathrm{~m}$.

3.2.6.2. Razão de relevo, integral hipsométrị ca, integral volumétrica e relaçäo de material erodido

- razão de relevo - determinada segundo SCHUMM (1956), sendo a relação entre a diferença de cota dos pontos extremos da bacia hidrográfica e o seu comprimento; (STRAHLER, 1957) .

A razão de relevo indica o declive total da 
bacia hidrográfica, constituindo um número sem dimensão e, portanto, podendo ser correlacionado com outras medidas, independendo do tamanho da bacia (STRAHLER, 1957).

- integral hipsométrica (IH) - avaliação do relevo atraves de curvas hipsométricas (STRAHLER, 1952'). Pla nimetraram-se as áreas compreendidas entre a primeira curva de nível e a linha do divisor de águas, na sua parte mais al ta e, a seguir, as àreas entre uma curva e a seguinte. Foram estabelecidas as relações de áreas (a/A) entre a área projetada entre duas curvas (a) e a área total da bacia (A), anotando-se os valores da distância vertical entre as curvas de nível (h) e a diferença entre a maior e a menor altitude da bacia (H). Os valores de a/A foram plotados no eixo "x" e os valores de h/H, no eixo "y".

A curva hipsométrica (STRAHLER, 1952) é construída para representar a distribuição do material existente, desde as partes mais baixas até as mais altas, em relação a uma unidade geométrica de referência que consiste de um sóli do limitado lateralmente pela projeção vertical do perímetro da bacia, no topo e na base, por planos paralelos passando $\underline{\text { a }}$ través do cume e da desembocadura, respectivamente. o valor da integral hipsométrica seria o equivalente à relação da área localizada sob a curva hipsométrica em função da área to tal que a contém.

- integral volumétrica (IV) - foi obtida segundo o método empregado por VIEIRA (1978), PIEDADE (1980) e 
CARVALHO (198I) em estudos de bacias hidrográficas de 3ạ ordem.

Conhecendo-se a altura e a área de cada faixa entre as curvas de nível, calcularam-se os volumes de solo, através da aplicação da seguinte fórmula: $v=(h l-h) x\left(a+a_{l}\right)$ /2. A somatória dos valores obtidos fomece o volume total (V) do solo compreendido pelo plano horizontal (base plana) que passa pelo ponto mais baixo da bacia e o plano inclinado gue a contorna. Calculados os volumes parciais (v) e os volu mes totais (V), estabeleceram-se os valores relativos $\mathrm{V} / \mathrm{V}$, que Eoram demarcados no mesmo gráfico da integral hipsométrica.

- relação do material erodido: (IH - IV) - no espaço total do quadrado que corresponde ao volume global, a área situada acima da curva hipsométrica representa o volume erodido e a área que fica abaixo da mesma curva equivale ao volume existente antes do início da formação dos vales; mas, considerando-se o perímetro atual. Do mesmo modo, a área situada abaixo da curva volumétrica equivale ao volume existen te, ainda não erodido. Segundo VIEIRA (1978), a diferença en tre a integral hipsométrica e a integral volumétrica corresponde ao grau de desenvolvimento da erosão.

\subsection{7 - Determinações de campo}

Com auxílio de cartas placo-hipsométricas e fotografias aéreas, foram realizados caminhamentos pela área, onde 
se efetuaram observações nos cortes de estradas e tradagens em locais onde não havia cortes. Através das informações obtidas, foram identificadas e caracterizadas as unidades de solo e então, procedeu-se à escolha de uma topossequência con tendo os solos representativos das unidades que se desejava estudar.

Devido à dificuldade de acesso às áreas das ba cias e, consequentemente, de abertura de trincheiras, a morfologia foi efetuada à profundidade dos barrancos disponíveis.

3.2.8. Determinações de laboratório

Para as analises quimicas, as amostras foram preparadas e analisadas conforme a metodologia convencional. As determinações químicas realizadas foram: o pH em água foi determinado potenciometricamente, usando-se a relaçäo solo/água 1:2̇,5; a matéria orgânica foi determinada pelo método de Walkley e Black; o fósforo e o potássio, extraídos pelo método de Mehlich, foram determinados, respecti vamente com azul de molibdênio e pela fotometria de chama; o cálcio, o magnésio e o alumínio, extraídos com solução de KCl $1 \mathrm{~N}$, foram determinados $\left(\mathrm{Ca}^{+2}\right.$ e $\mathrm{Ng}_{\mathrm{g}}^{+2}$ ) por absorção atômica e $\left(\mathrm{AII}^{+3}\right)$ por titulaçäo com NaOH 0,025 N (EMBRAPA, 1979). A soma de ba ses trocaveis ( $S$ ) foi obtida somando-se os teores de $\mathrm{Ca}^{+2}$, $\mathrm{Mg}^{+2}$ e $\mathrm{K}^{+}$e a capacidade de troca catiônica (CTC) foi obtida pela soma de $\mathrm{S}, \mathrm{Al}^{+3}$ e $\mathrm{H}^{+}$. A saturação de bases (V\%) foi o $\underline{B}$ 
tida através da fórmula: Sx $100 / C T C ;$ enquanto, que a saturação de alumínio foi obtida pela fórmula: $\mathrm{Al}^{+3} \mathrm{X} 100 / \mathrm{Al}^{+3}+\mathrm{S}$ ( $\mathbb{E M}-$ BRAPA, 1979). A classificação dos dados das análises químicas foi feita de acordo com OLEYNIK (1980).

Os separados do solo foram determinados pelo método da pipeta (KILIMER e ALEXANDER, 1949), utilizando NaOH I N como dispersante e desagregaçäo por agitador horizontal. A areia total foi subdividida em duas frações e as classes texturais foram obtidas no diagrama do USDA (1951). A argila natural ou dispersa em água também foi determinada. 
4. RESULTADOS

Os resultados estão apresentados na sequência em que foram tratados no capítulo Material e Métodos, de forma a permitir a interoretação comparativa dos unidades de solo es tudadas.

4.1. Dados Climáticos.

Com os dados termo-pluviométricos foi elaborado - balanço hídrico médio mensal para a região, como mostrama Ta bela 2 e a Figura 2.

4.2. Características das Bacias Hidrográficas.

O mapa da rede de drenagem contendo as bacias hi drográficas de 3ạ ordem, selecionadas para este estudo, está contido na Figura 3. 
4.2.1. Análise dimensional e semelhança geométrica

As propriedades dimensionais das bacias hidrográficas, representativas das áreas estudadas, tais como: maior comprimento e maior largura, comprimento de rios princi pais e total da rede, perímetros e área estão na Tabela 3.

A análise dimensional e de semelhança geométrị ca aplicada às bacias das áreas estudadas constam da Tabela 4.

\subsubsection{Características do padrão de drenagem}

o número e comprimento de segmentos de rios ob servados em cada ordem de ramificação e o total para as bacias hidrográficas das áreas estudadas, estão apresentados na Tabela 5 .

Com base na Tabela 5, foram calculadas as características do padrão de drenagem e a classe de textura to pográfica das bacias para cada área, o que está apresentadona Tabela 6 .

Na Tabela 7, são apresentados os valores médios de frequência de rios, densidade de drenagem, razão de textura e razão de textura média com os seus respectivos erros padrão e coeficientes de correlação, além da classe de textura topográfica para as áreas estudadas.

Através dos dados da Tabela 6, foram efetuadas 
relações lineares entre frequência de rios ( $F$ ), densidade de drenagem (Dd) e razão de textura ( $T$ ) obtidas a partir das bacias hidrográficas, obedecendo o seguinte critério:

- relação entre frequência de rios (F) e densi dade de drenagem ( $\mathrm{Dd})$;

- relação entre razão de textura (T) e densidą de de drenagem (Dd);

- relação entre razão de textura (T) e frequên cia de rios (F).

As equações obtidas constam da Tabela 8.

4.3. Características do Relevo.

Os mapas das bacias de drenagem de $3 \underline{a}$ ordem, com curvas de nível de 10 em $10 \mathrm{~m}$, que representam as unidades de solo, constam das Figuras 4, 5 e 6 (Latossolo Roxo), das Figuras 7, 8 e 9 (Terra Roxa Estruturada) e da Figura 10 (Litossolo fase substrato basaltito).

4.3.1. Razão de relevo

A Tabela 9 apresenta dados de altitude, amplitude altimétrica, maior comprimento da bacia e razão de relevo. 


\subsubsection{Integrais hipsométricas e volumétricas}

Nas Tabelas 10, II e 12 (Latossolo Roxo), nas Tabelas 13, 14 e 15 (Terra Roxa Estruturada) e nas Tabelas 16, 17 e 18 (Litossolo fase substrato basaltito), está apresentada a sequência de cálculos para a obtenção das integrais hipsométricas e integrais volumétricas.

Os valores hipsométricos (maior e menor altitu de, integral hipsométrica, integral volumétrica e relação de material erodido) estão na Tabela 19.

As integrais hipsométricas e volumétricas estão representadas na Figura 11 (Latossolo Roxo), Figura I2 (Tẹ ra Roxa Estruturada) e Figura 13 (Litossolo fase substrato ba saltito).

4.4. Características Morfológicas, Granulométricas e Químicas dos Solos Estudados

4.4.1. Descrição morfológica

A descrições morfológicas dos perfis de Latossolo Roxo, Terra Roxa Estruturada e Litossolo fase substrato ba saltito constam das Tabelas 20,21 e 22 , respectivamente.

4.4.2. Análise granulométrica e uímica

Os resultados da análise granulométrica dos 
perfis dos solos representativos das unidades Latossolo Roxo, Terra Roxa Estruturada e Litossolo fase substrato basaltito constam das Tabelas 23,24 e 25, respectivamente.

os resultados da análise química dos cátions trocaveis do solo para os perfis estudados, constam da Tabela 26 (Latossolo Roxo), Tabela 27 (Terra Roxa Estruturada) e Tabela 28 (Litossolo fase substrato basaltito). 


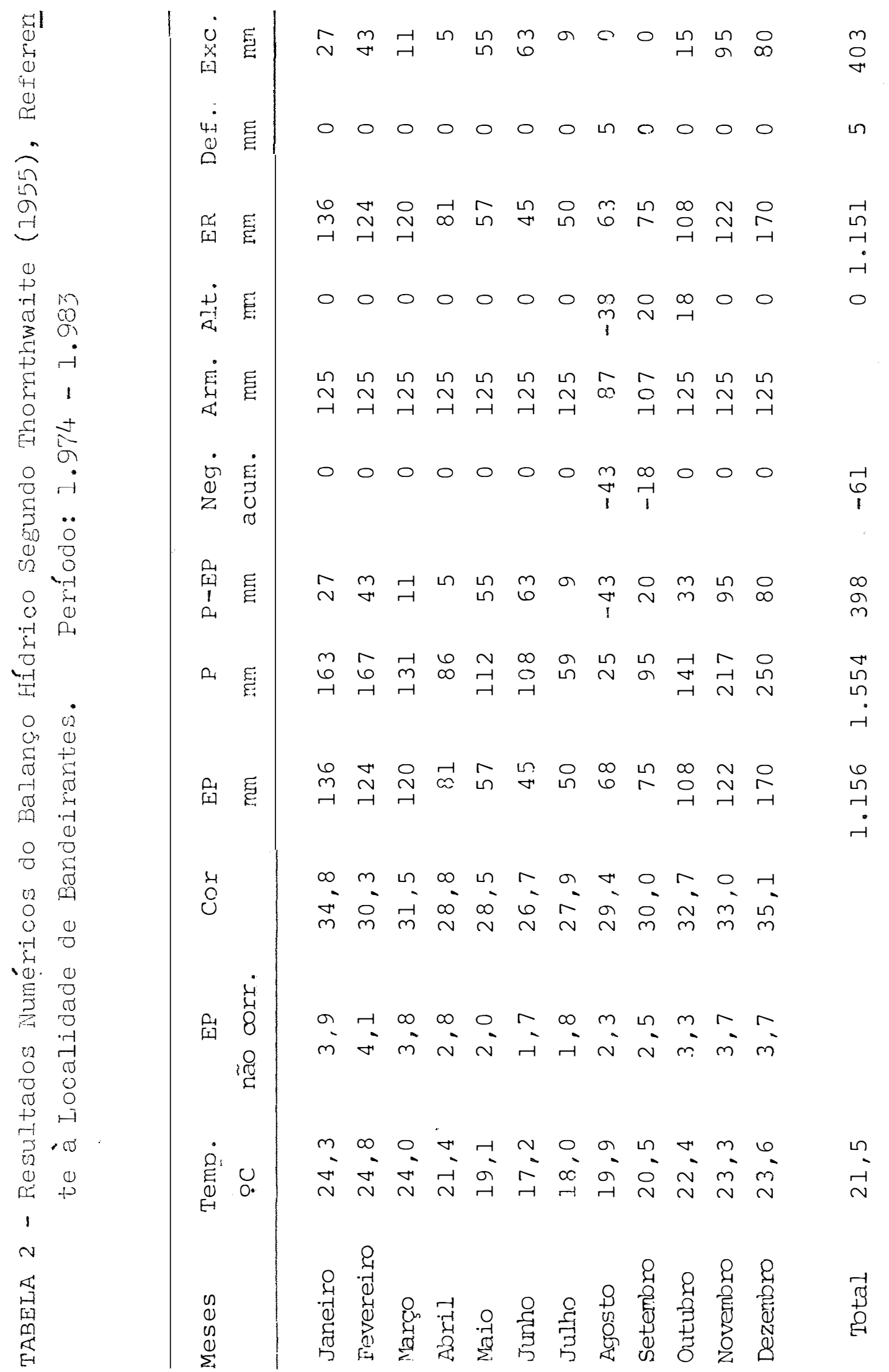




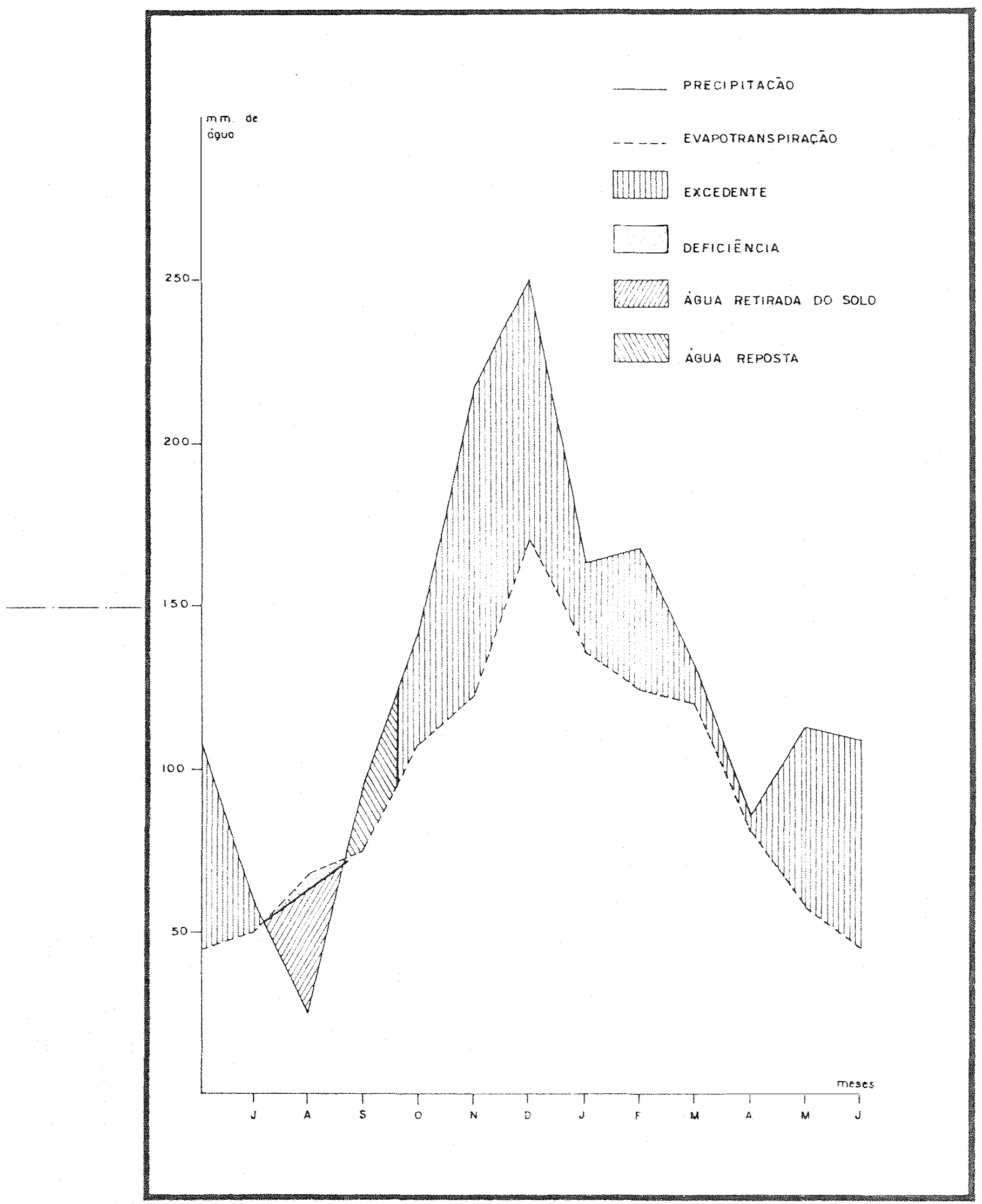

Fig. 2 Representusōo Gráfico do Balanço Hidrico Segundo Thornthwoite (1.955), Referente a Localidode de Ëandeirantes. Periodo de 1.974 - 1.983 


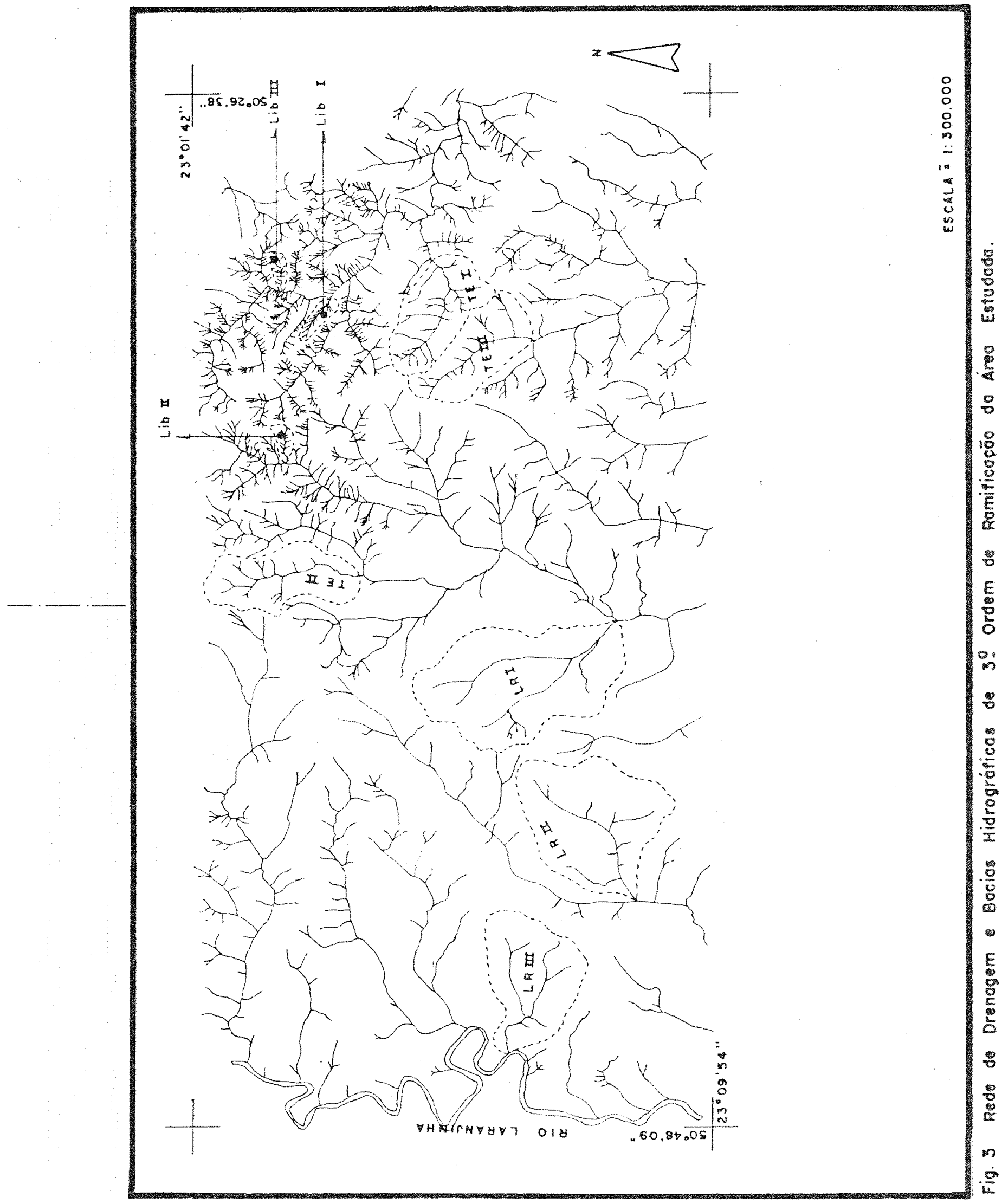




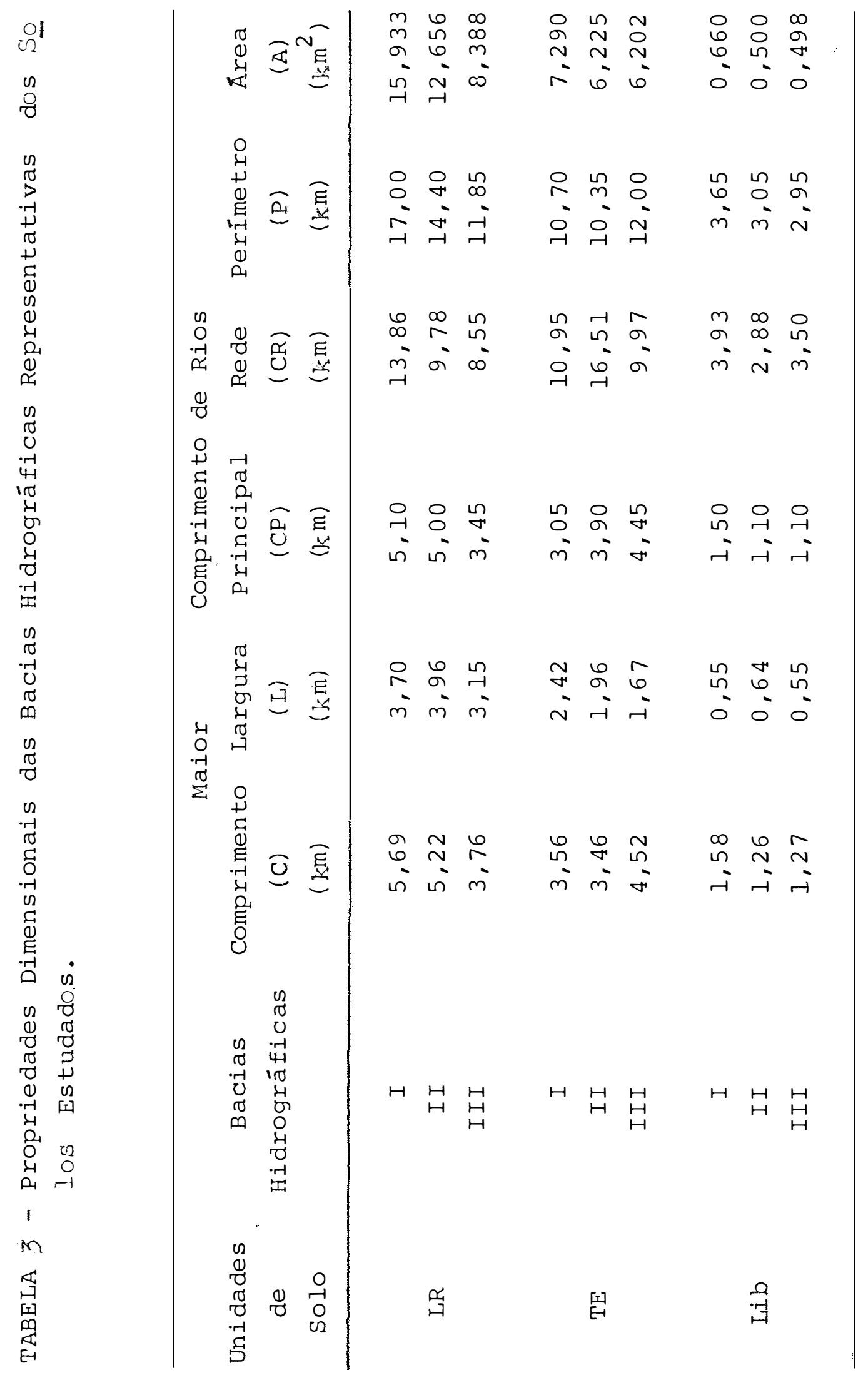




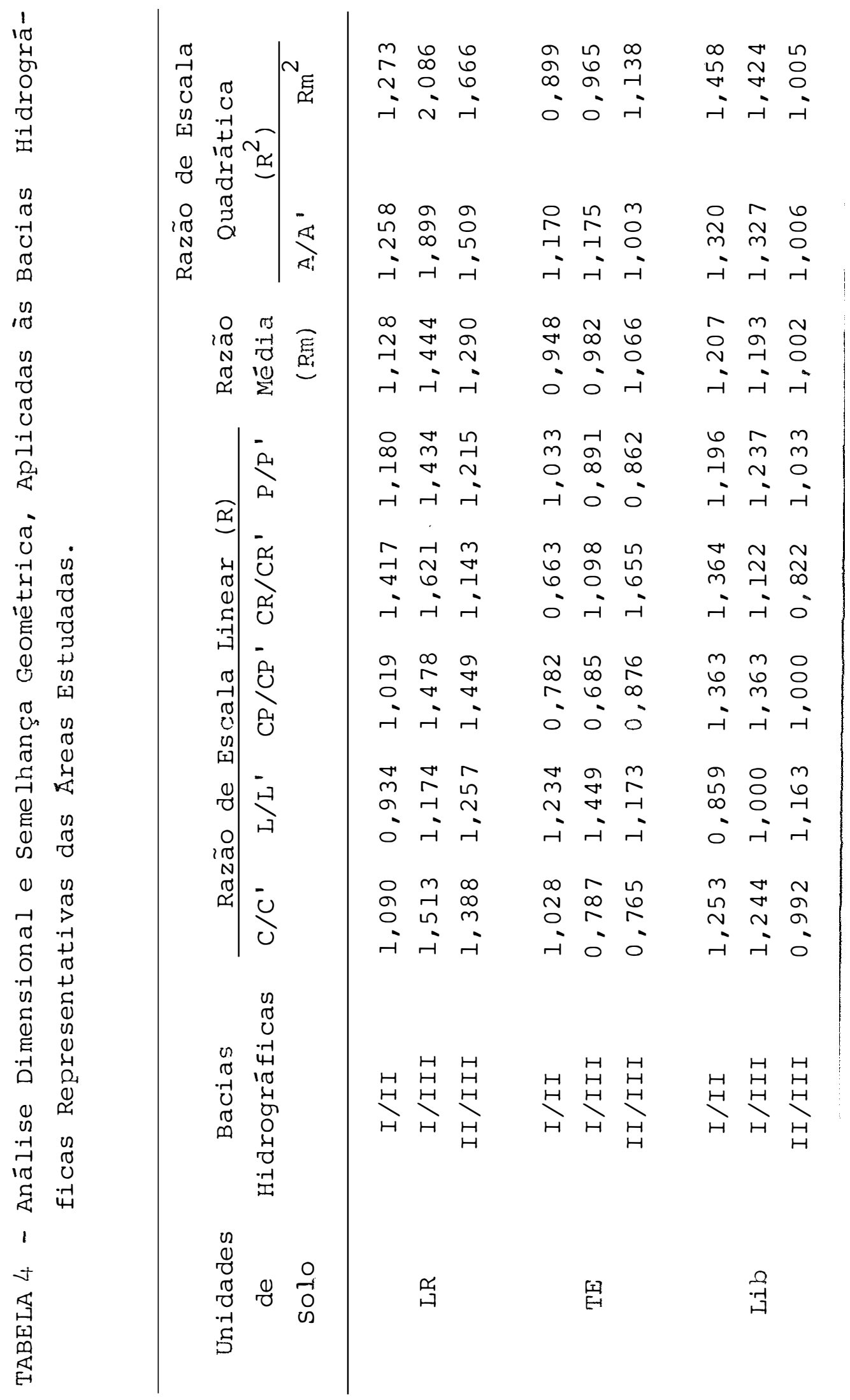



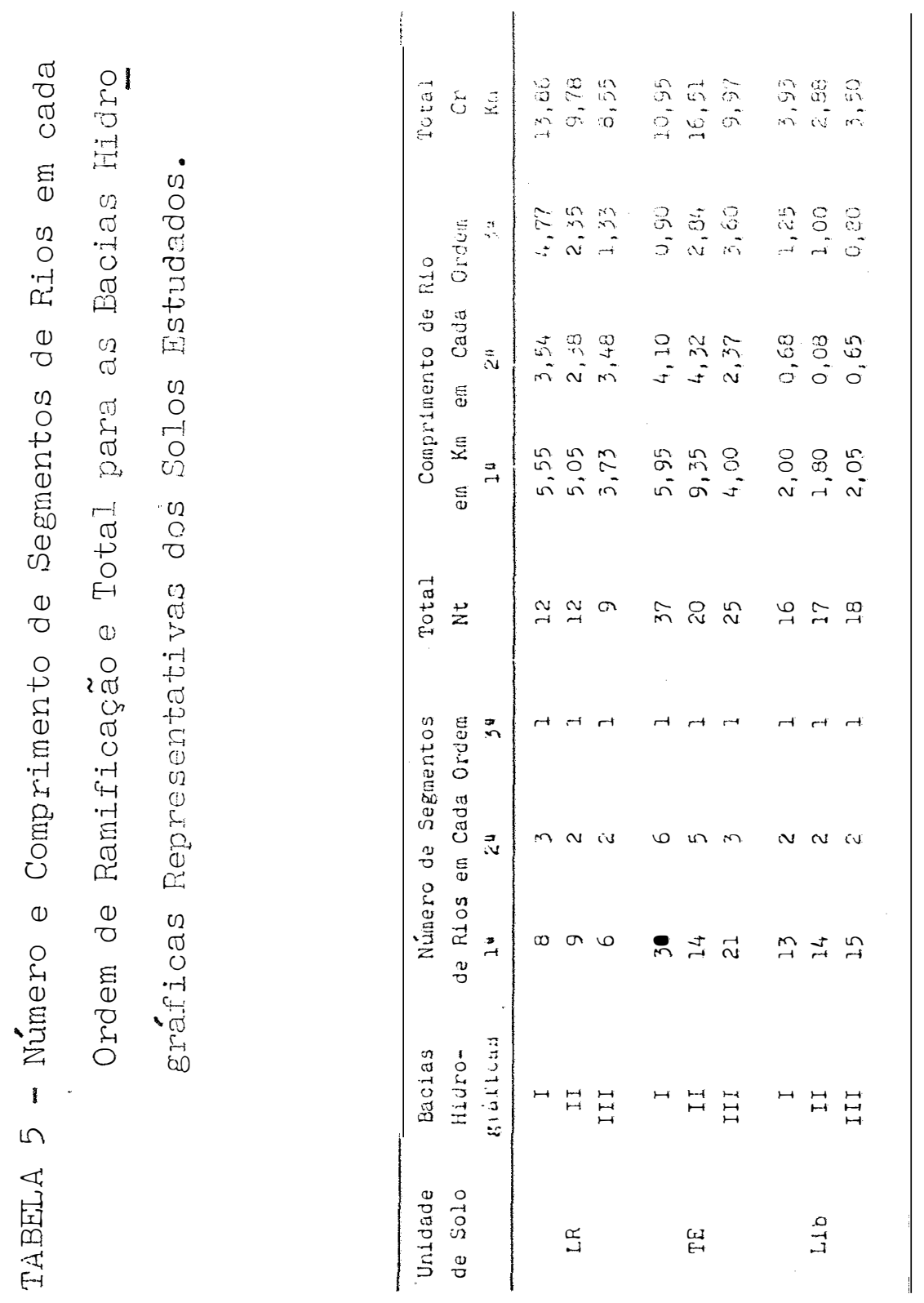


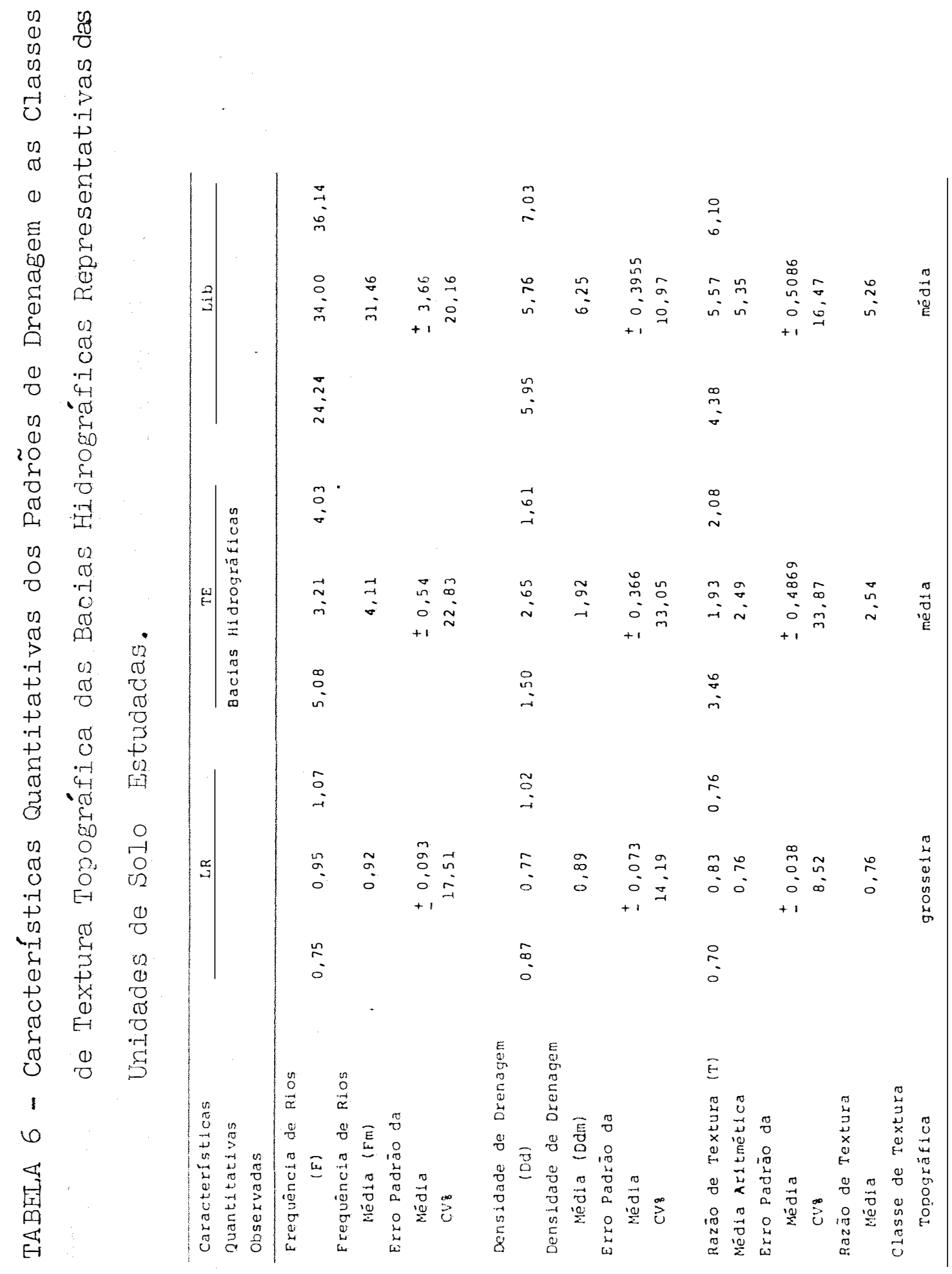



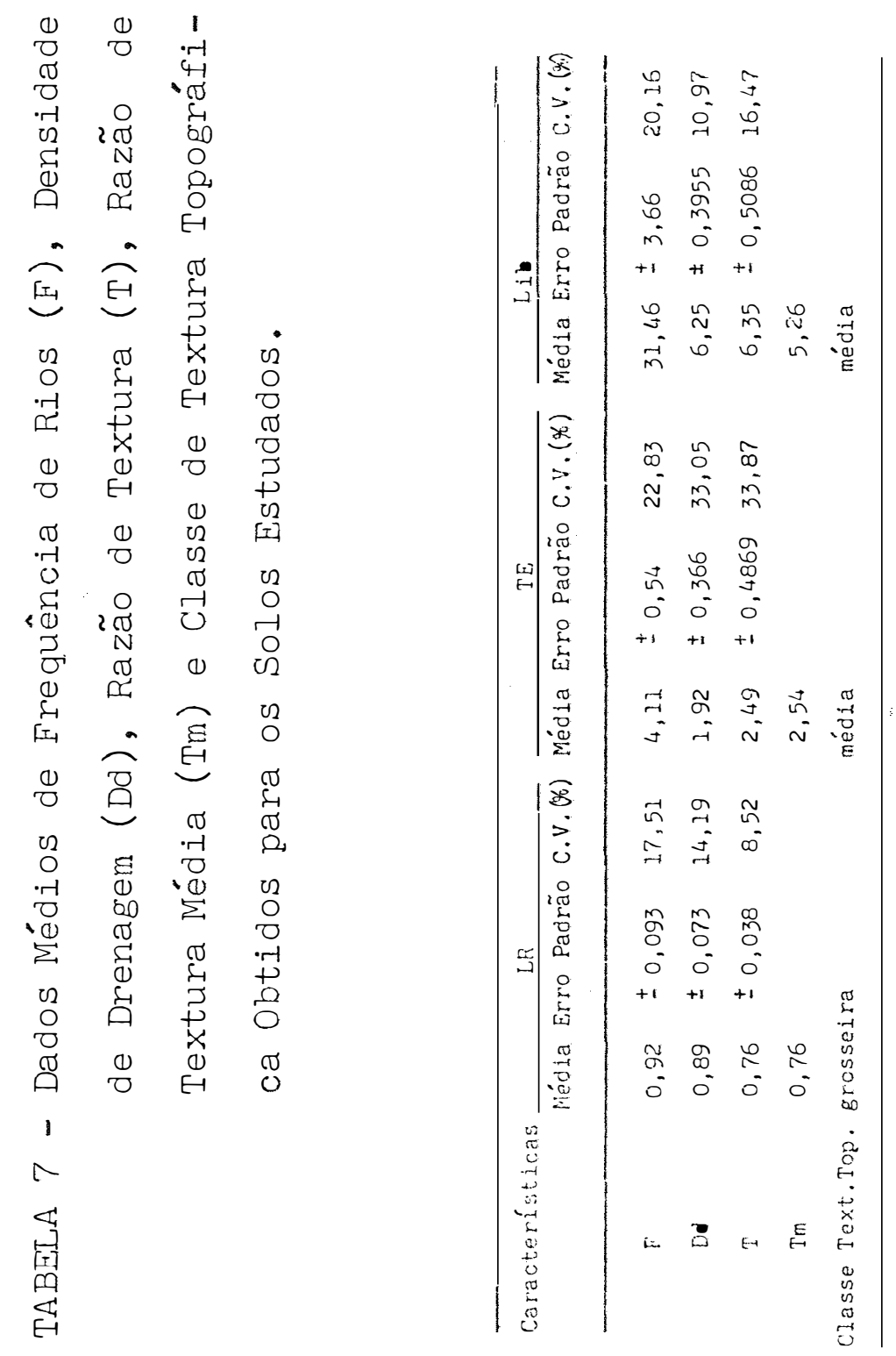

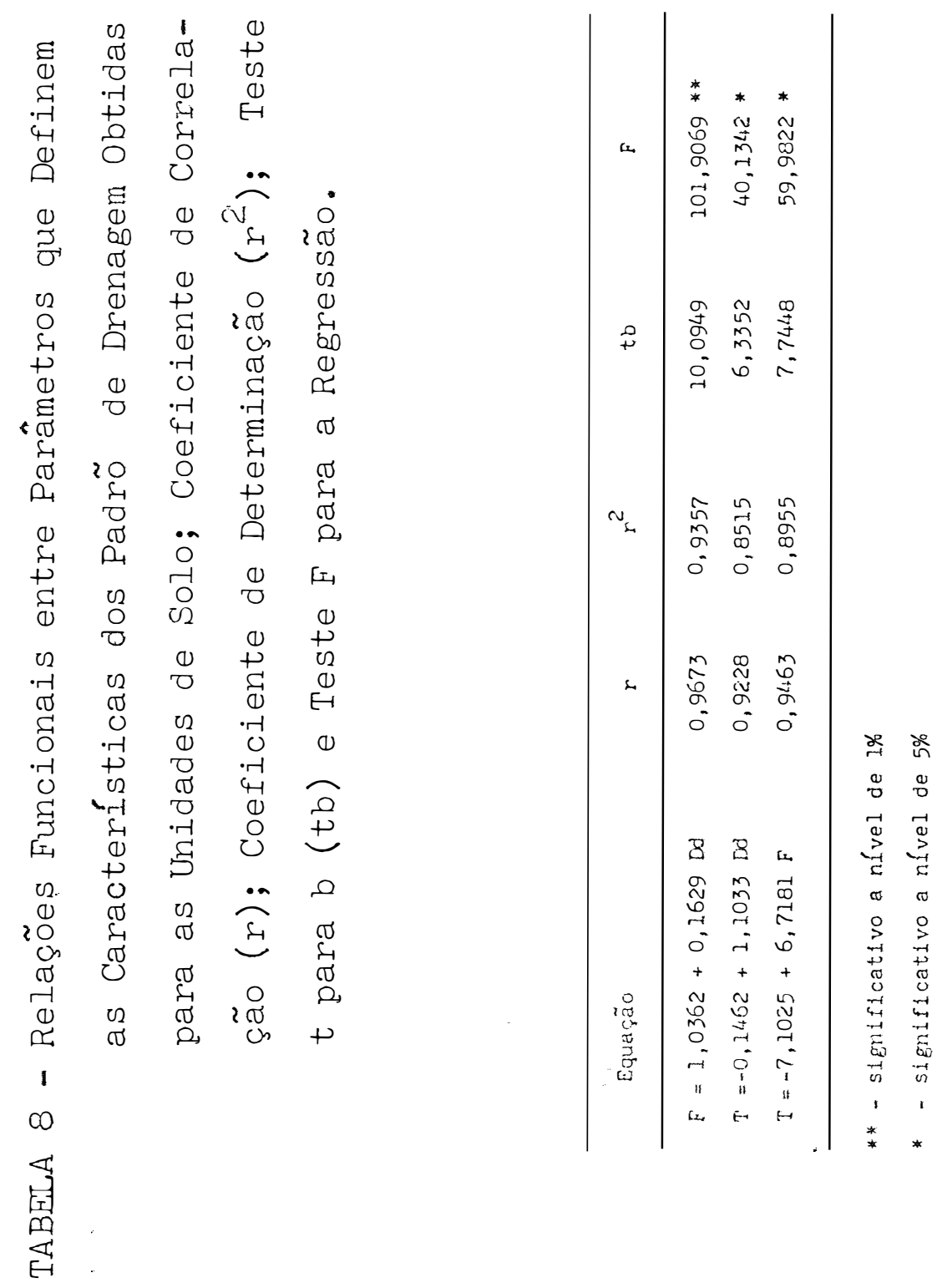


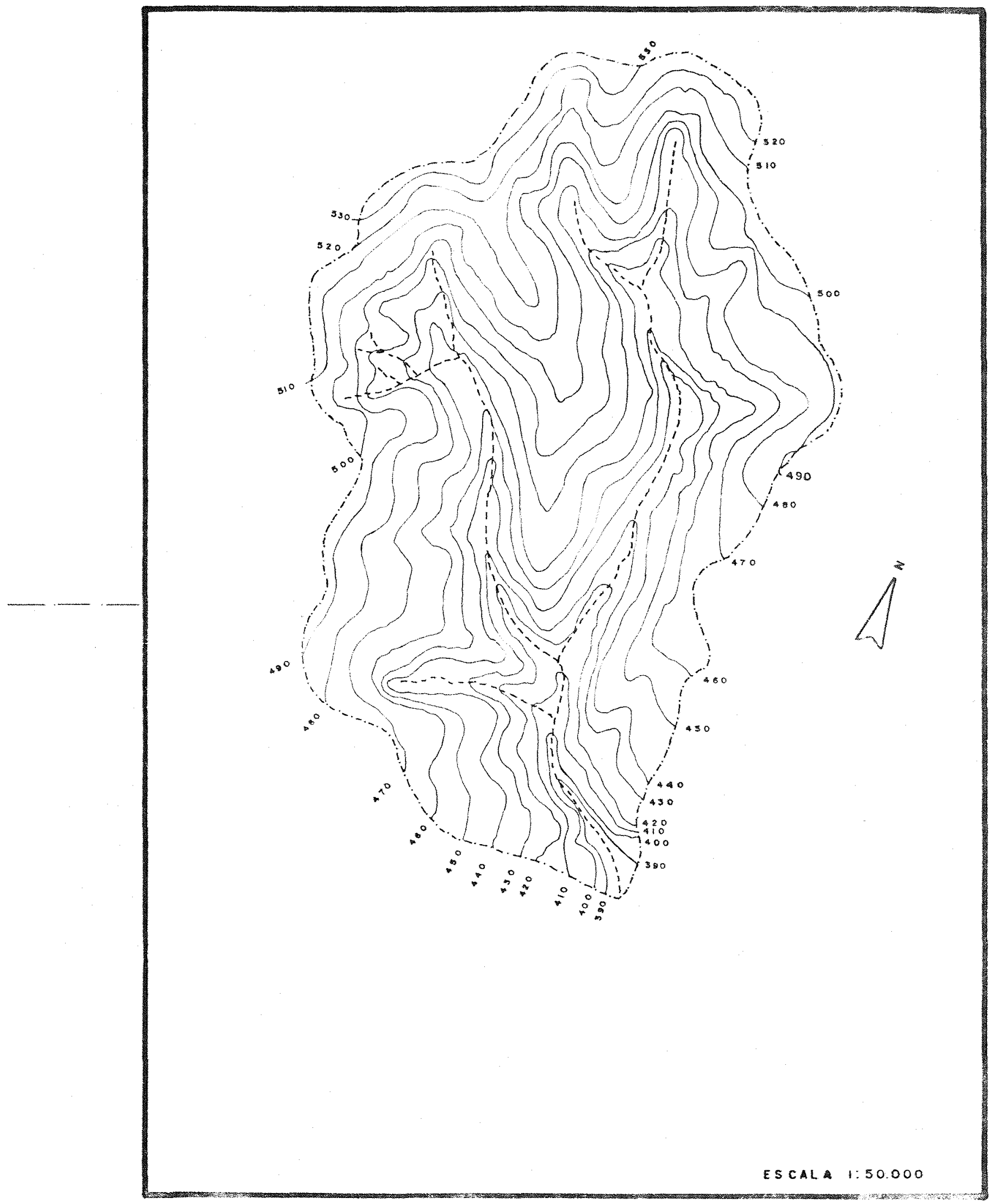

Fig. 4 Eacia Hidrográfica I Represeniativa da Unidade de Solo LR 


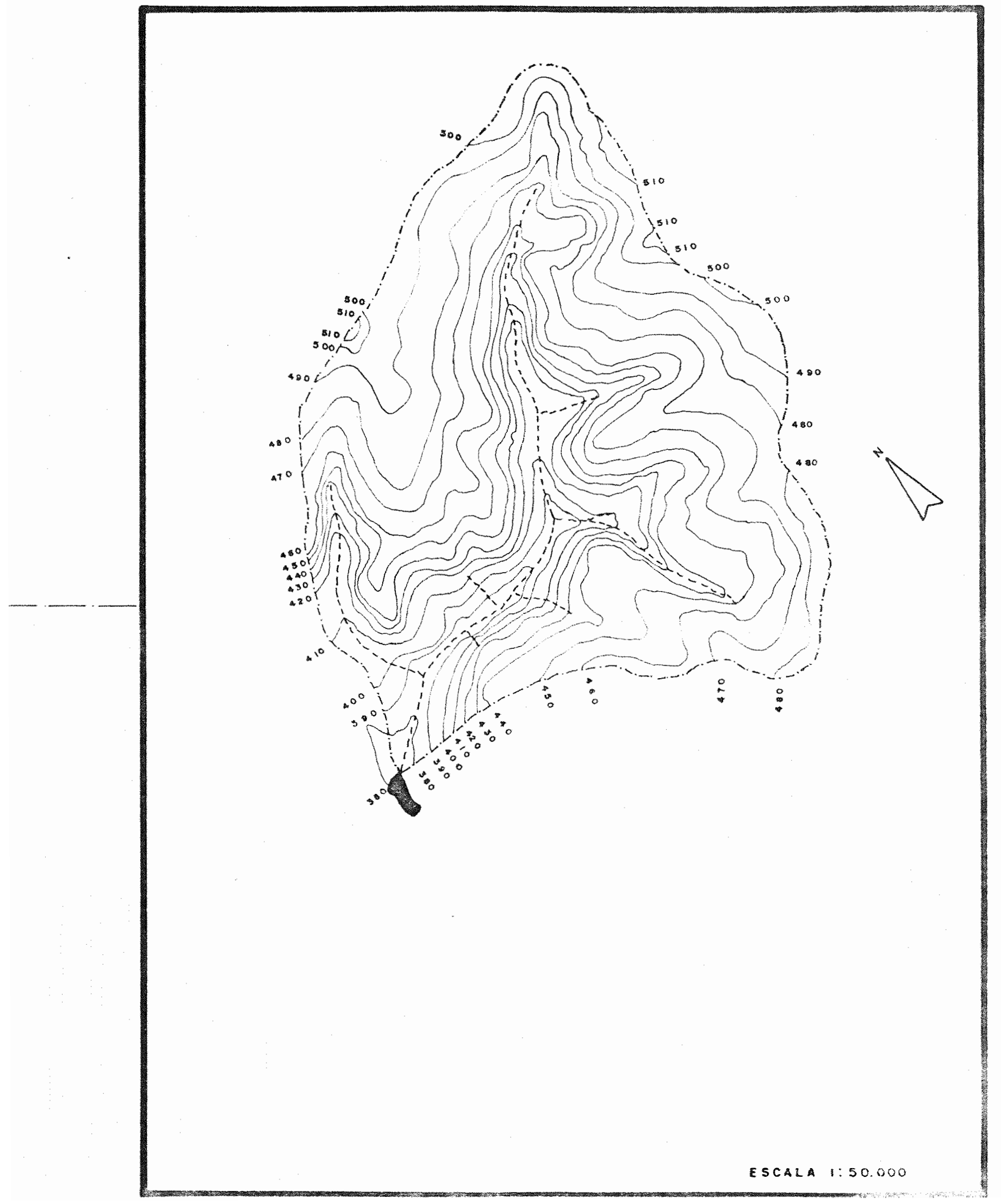

Fig. 5 Bocio Hidrogrática II Representativa da Unidade de Solo LR 


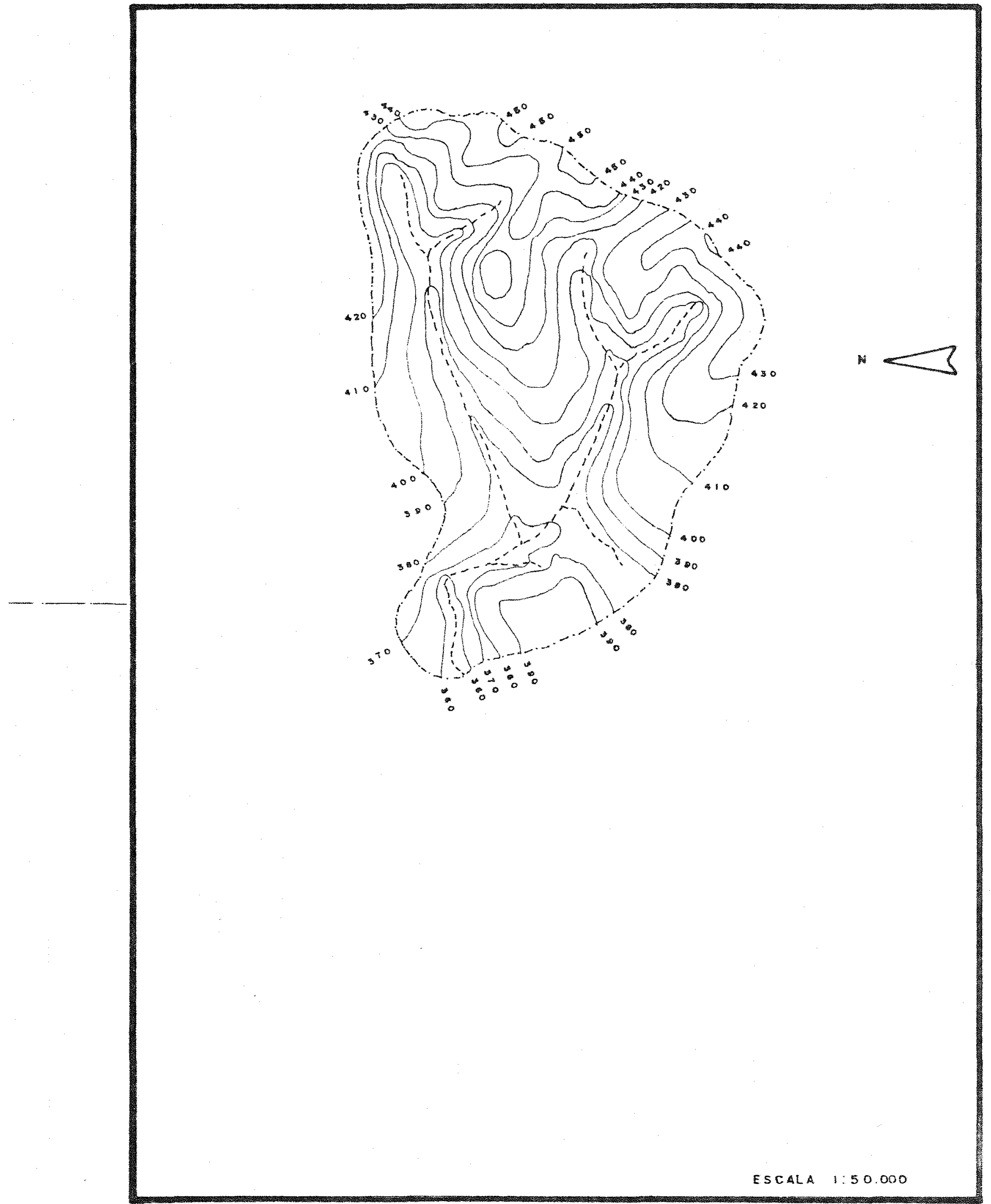

Fig. 6 Bacia Hidrogratica II Representativa da Unidade de Solo LR 


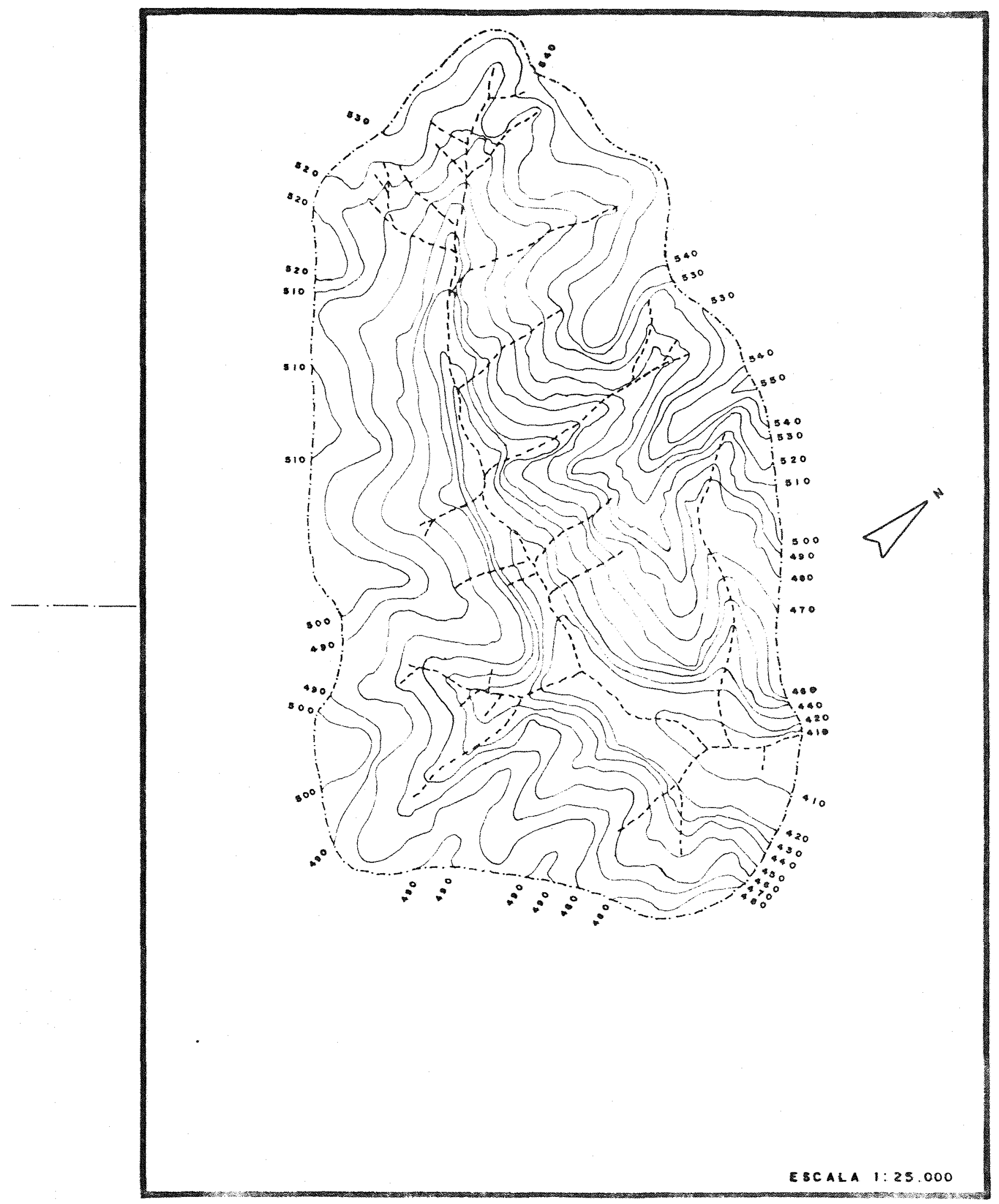

Fig. 7 Eecia Hidrogrófico I Representoliva do Unidode de SOlo TE. 


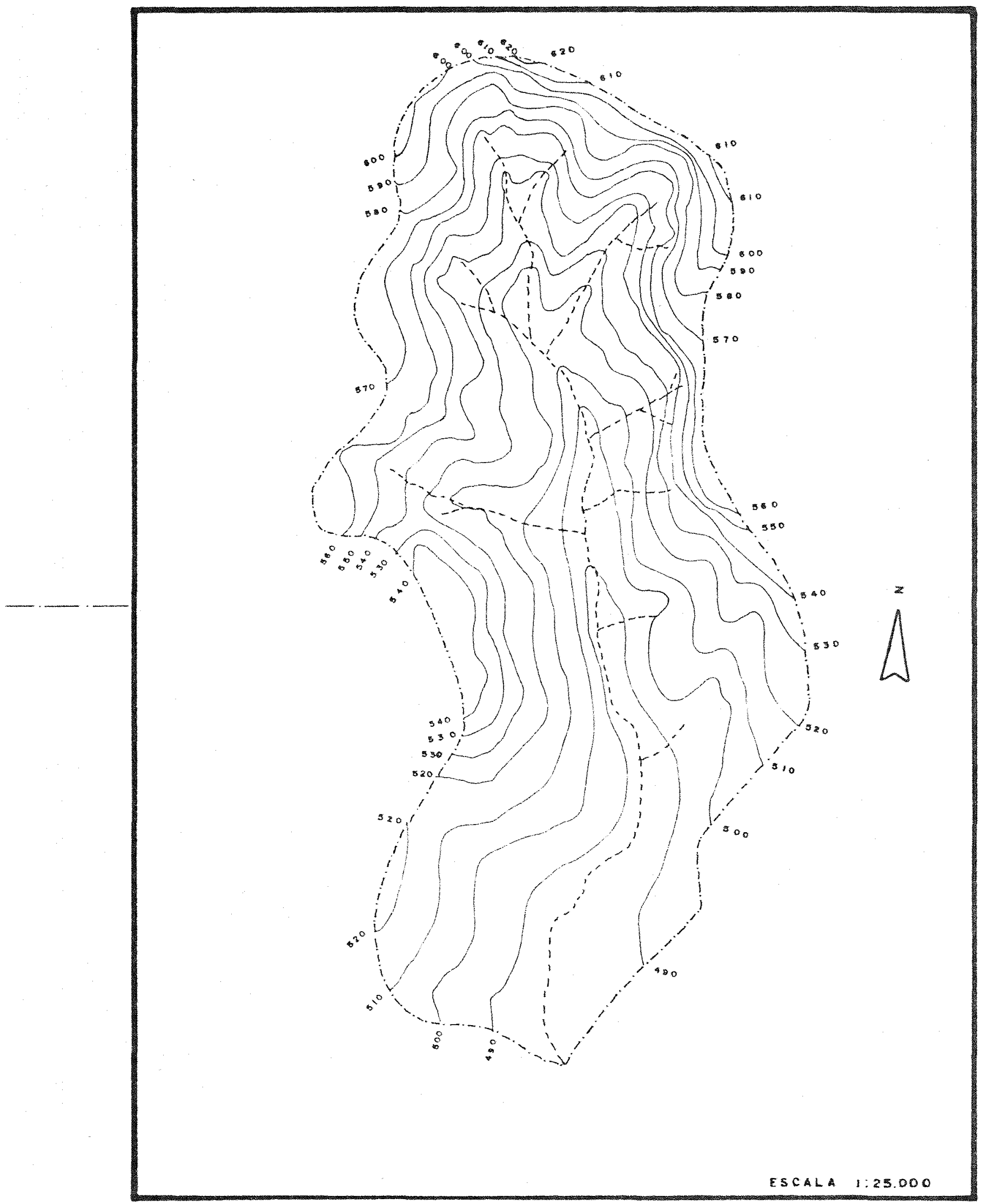

Fig. 8 Bacio Hidrogrofico II Representotivo do Unidade de Solo TE 


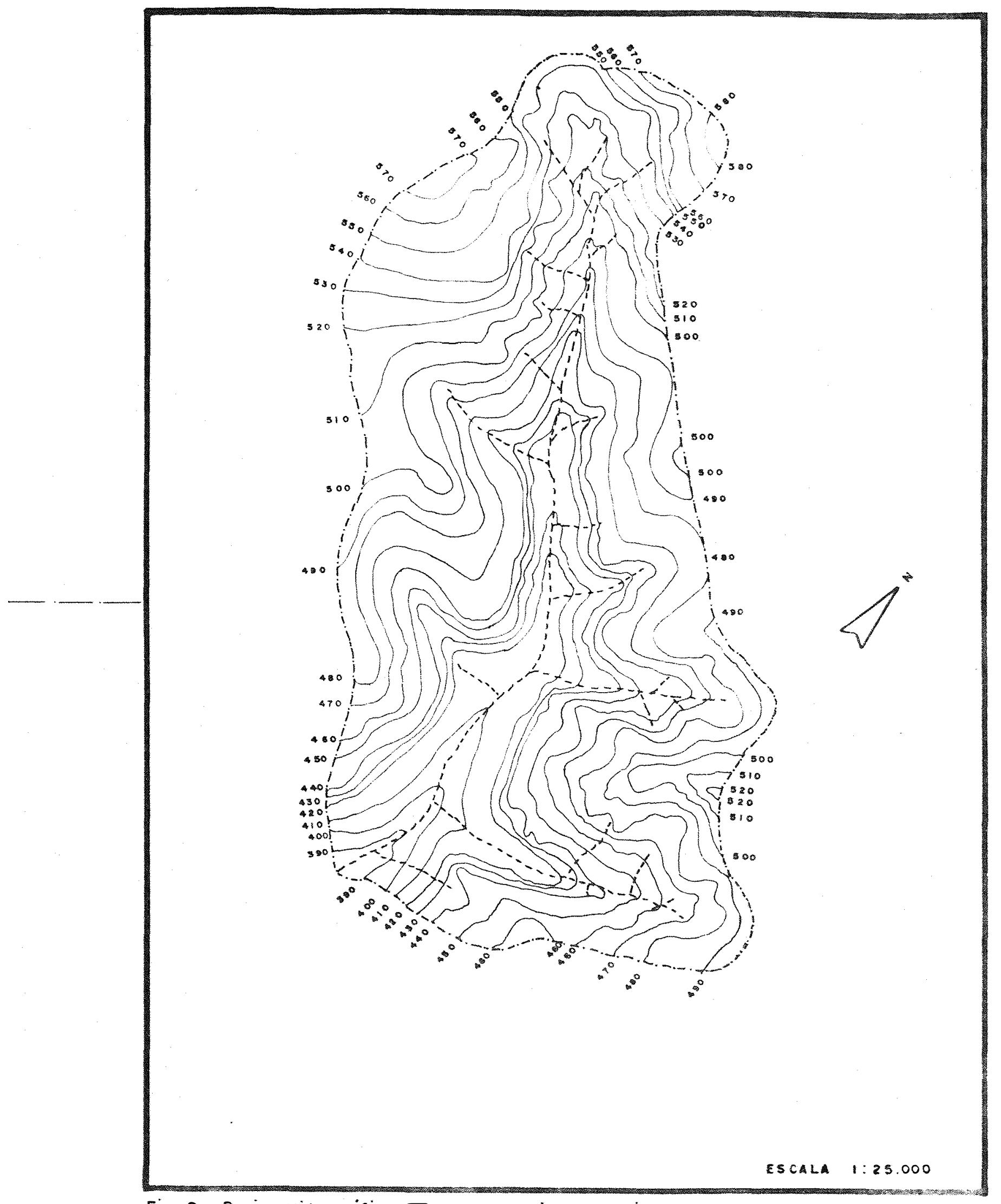

Fig. 9 Bocio Hidrogrófico III Representativo do Unidode de Solo TE. 


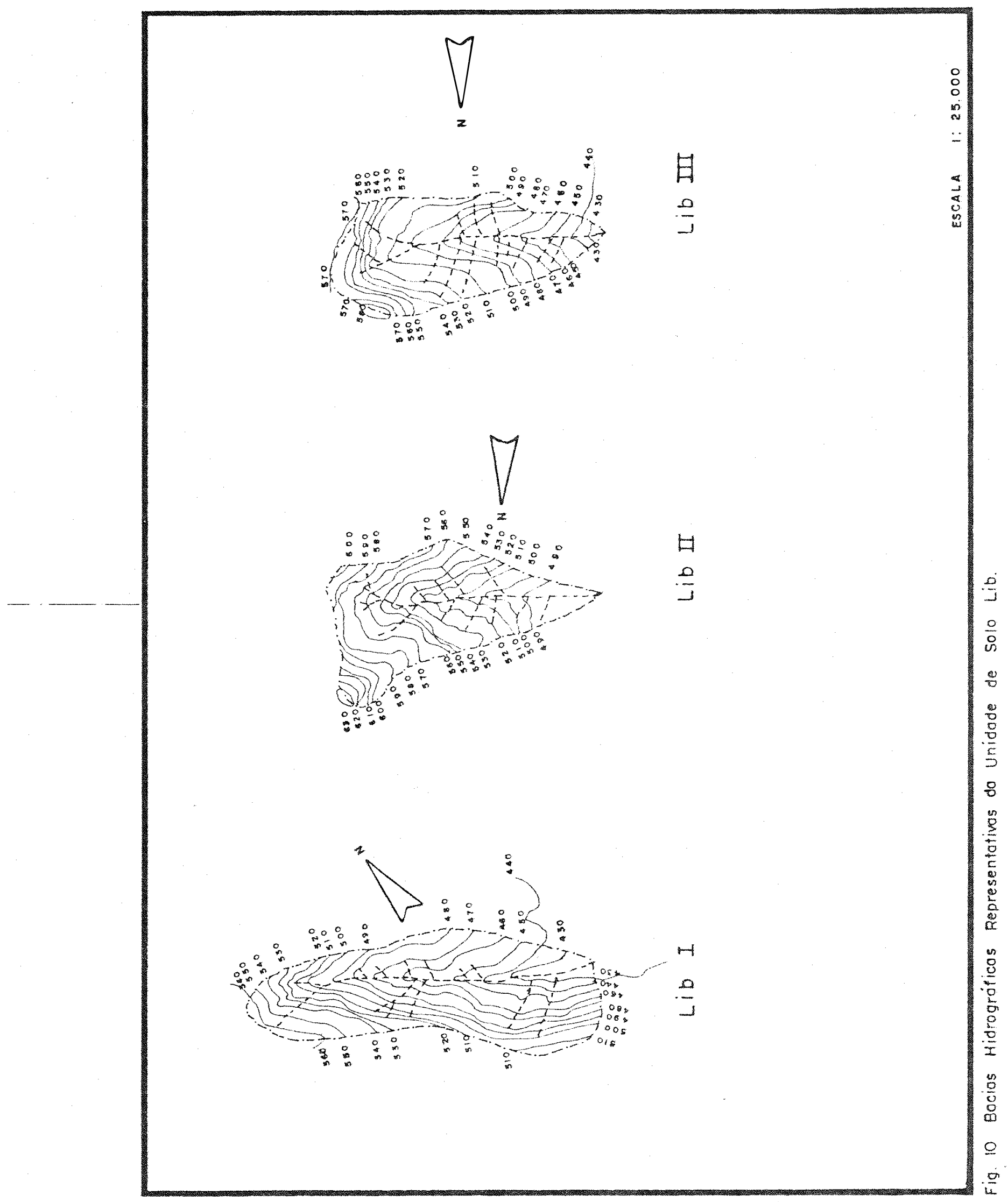




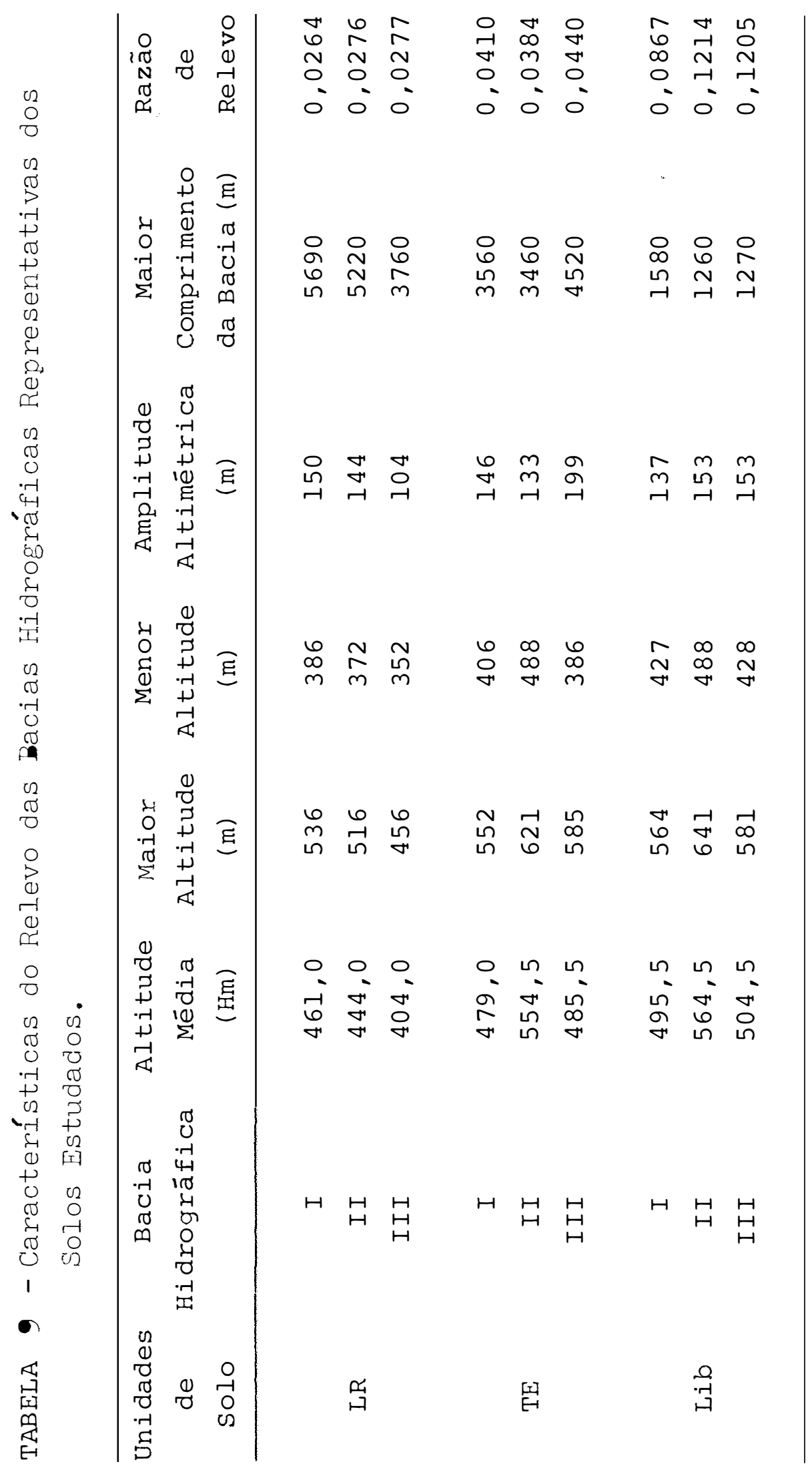



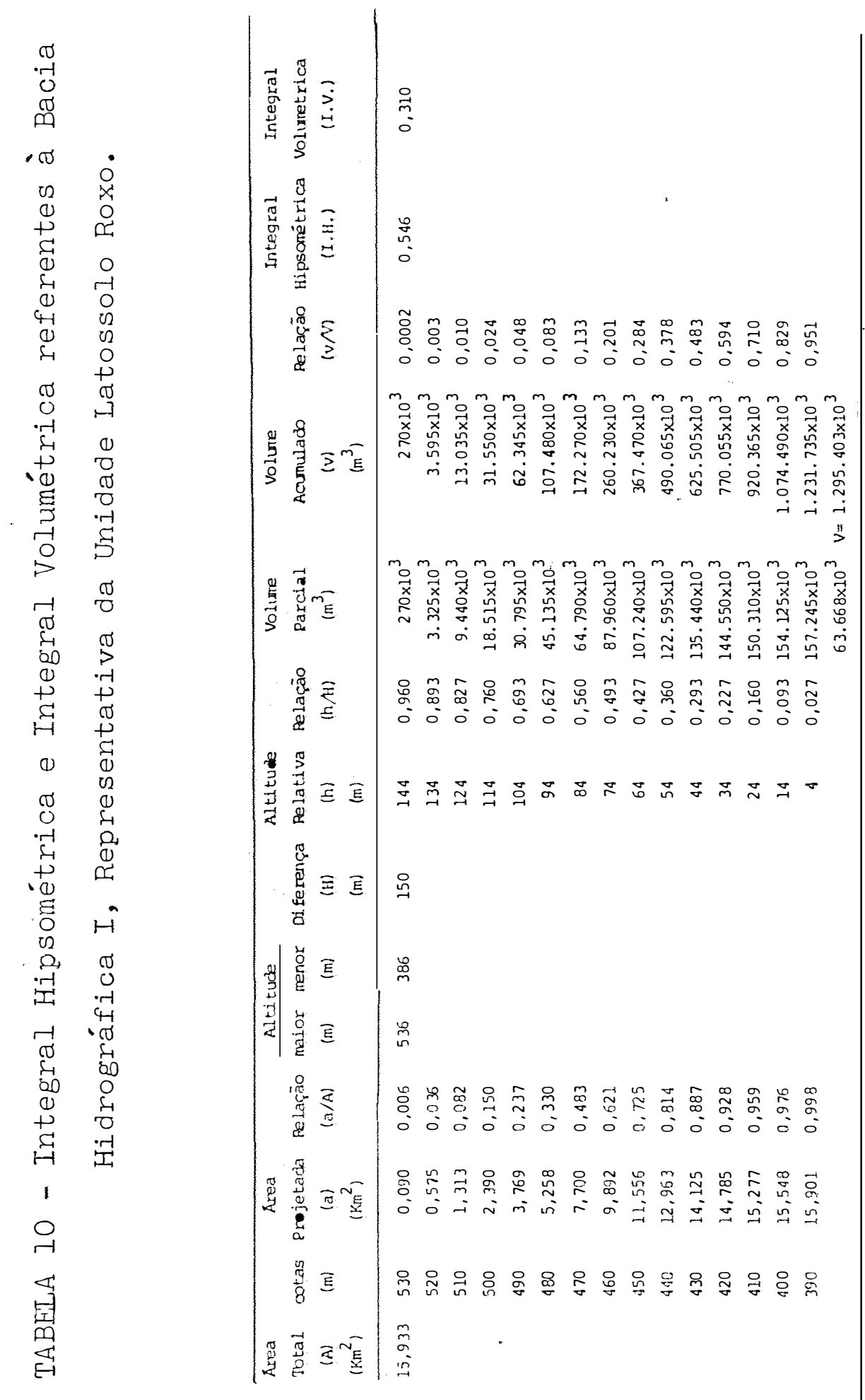


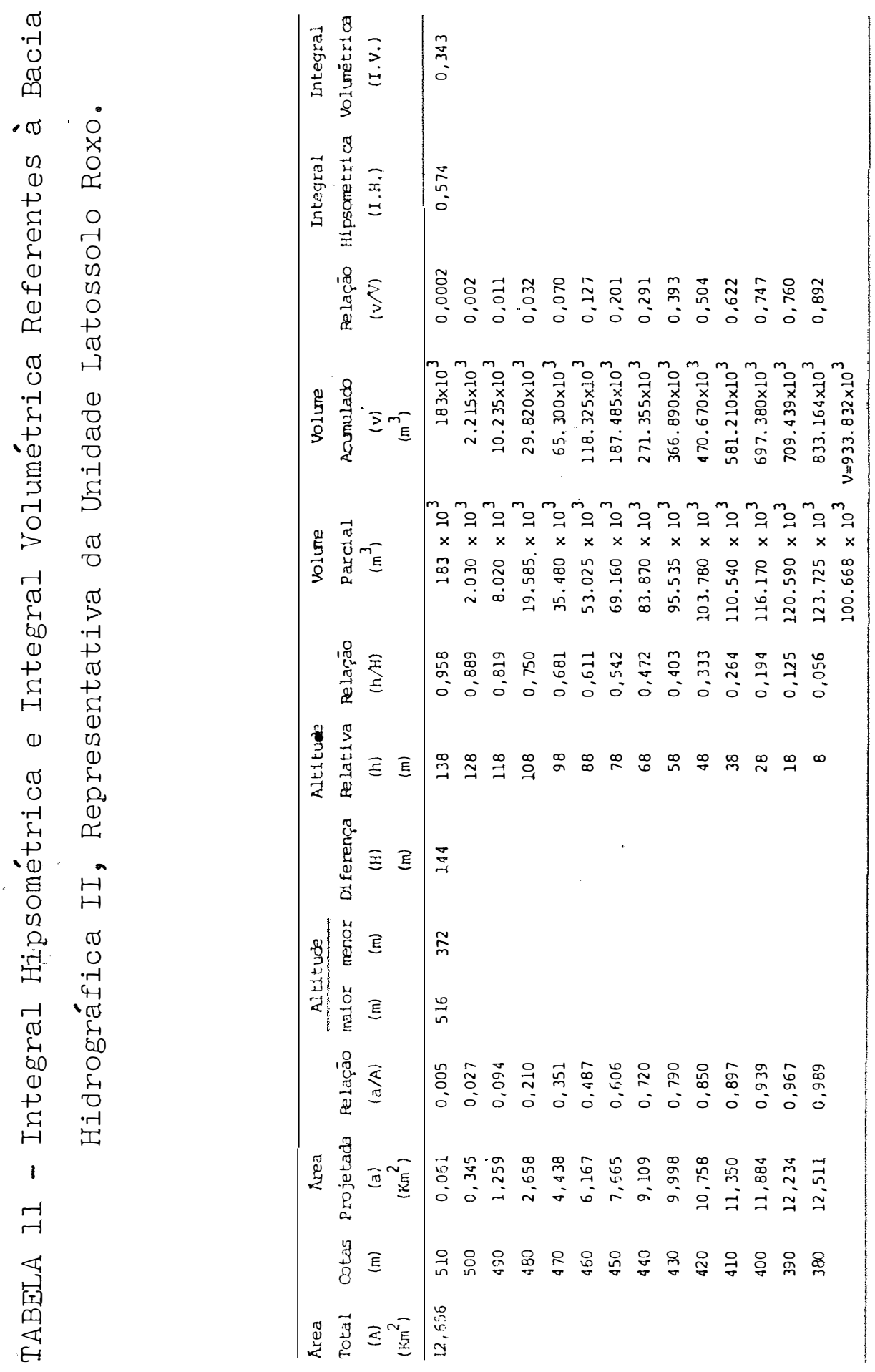



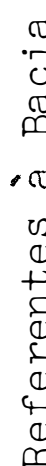

0

o

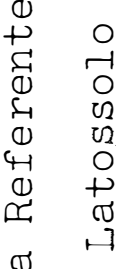

o 0

मे व

+ه

韋

$\circ$
$>\quad 0$

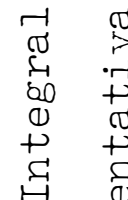

(1) प

ช)

म्न

葛

.

I

๘

80

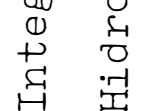

異

\begin{tabular}{|c|c|}
\hline 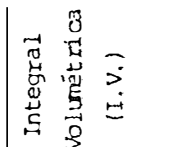 & 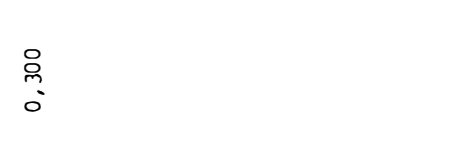 \\
\hline 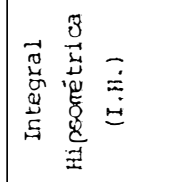 & $\underset{n}{3}$ \\
\hline 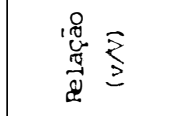 & 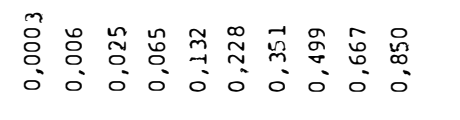 \\
\hline 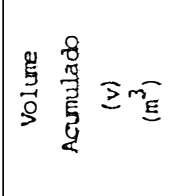 & 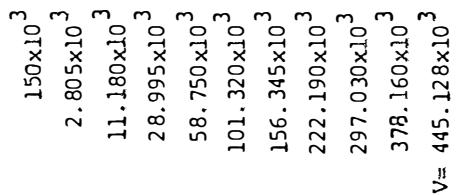 \\
\hline 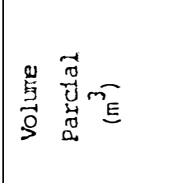 & 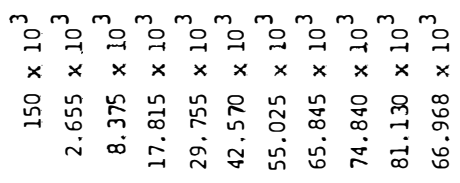 \\
\hline 总 & 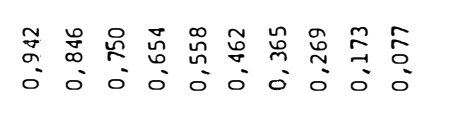 \\
\hline 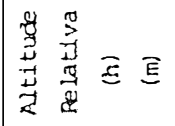 & $\stackrel{\infty}{\infty} \underset{\infty}{\infty} \stackrel{\infty}{\sim} \stackrel{\infty}{\sim} \stackrel{\infty}{\sim} \stackrel{\infty}{\sim} \stackrel{\infty}{\sim} \stackrel{\infty}{\sim}$ \\
\hline 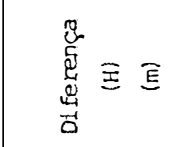 & $\stackrel{\circ}{\triangle}$ \\
\hline 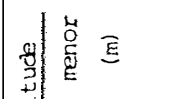 & $\tilde{\tilde{m}}$ \\
\hline 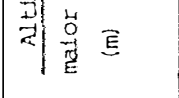 & . \\
\hline 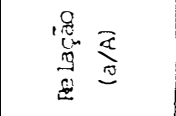 & 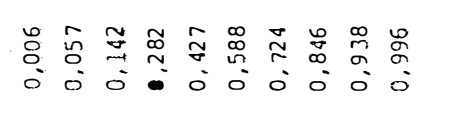 \\
\hline 要 & 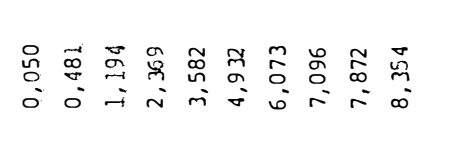 \\
\hline 要 $\bar{E}$ & 암 암 윰 \\
\hline 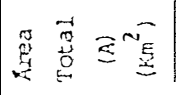 & 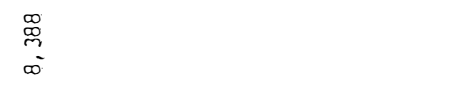 \\
\hline
\end{tabular}



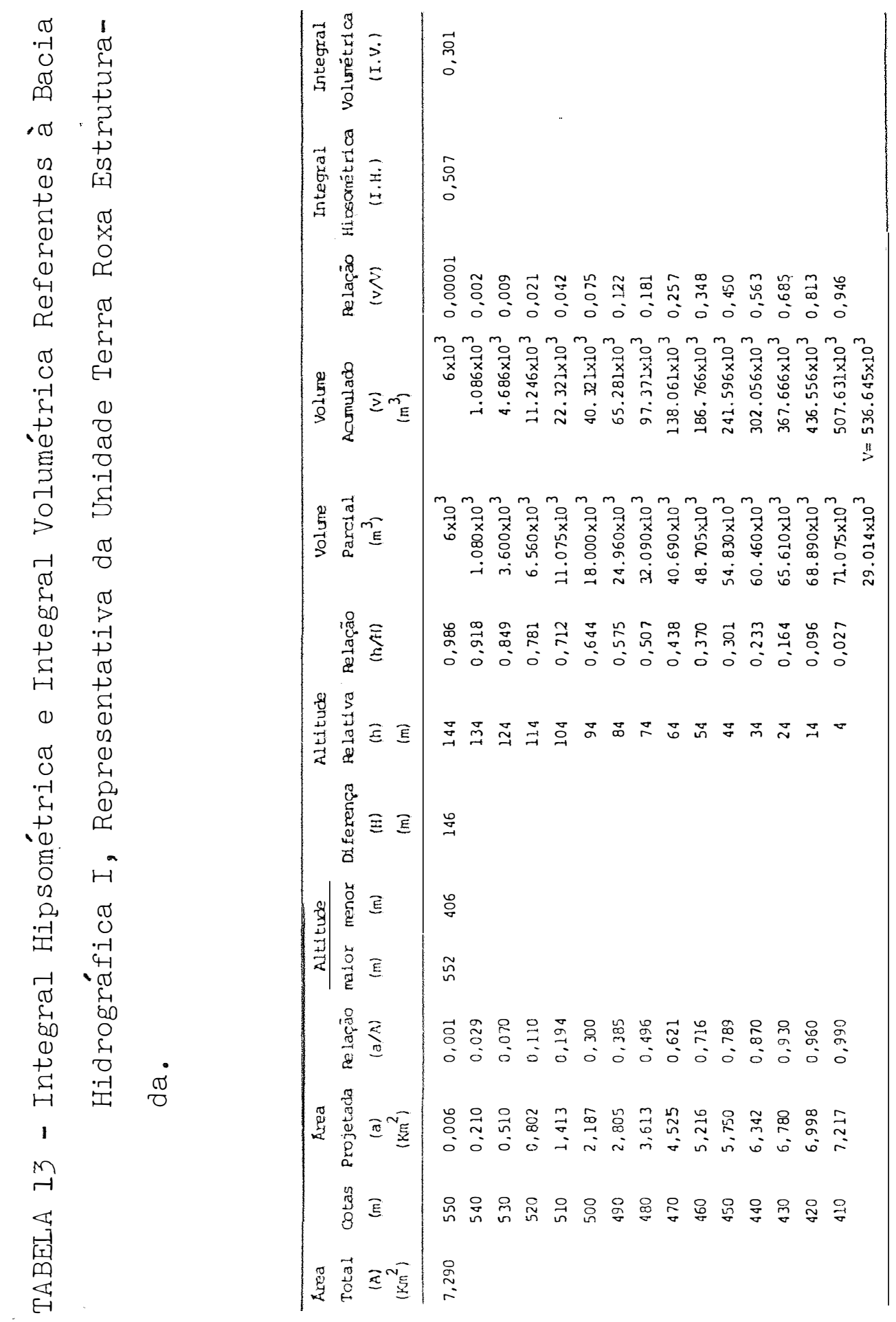
1
0
1
0
0
0

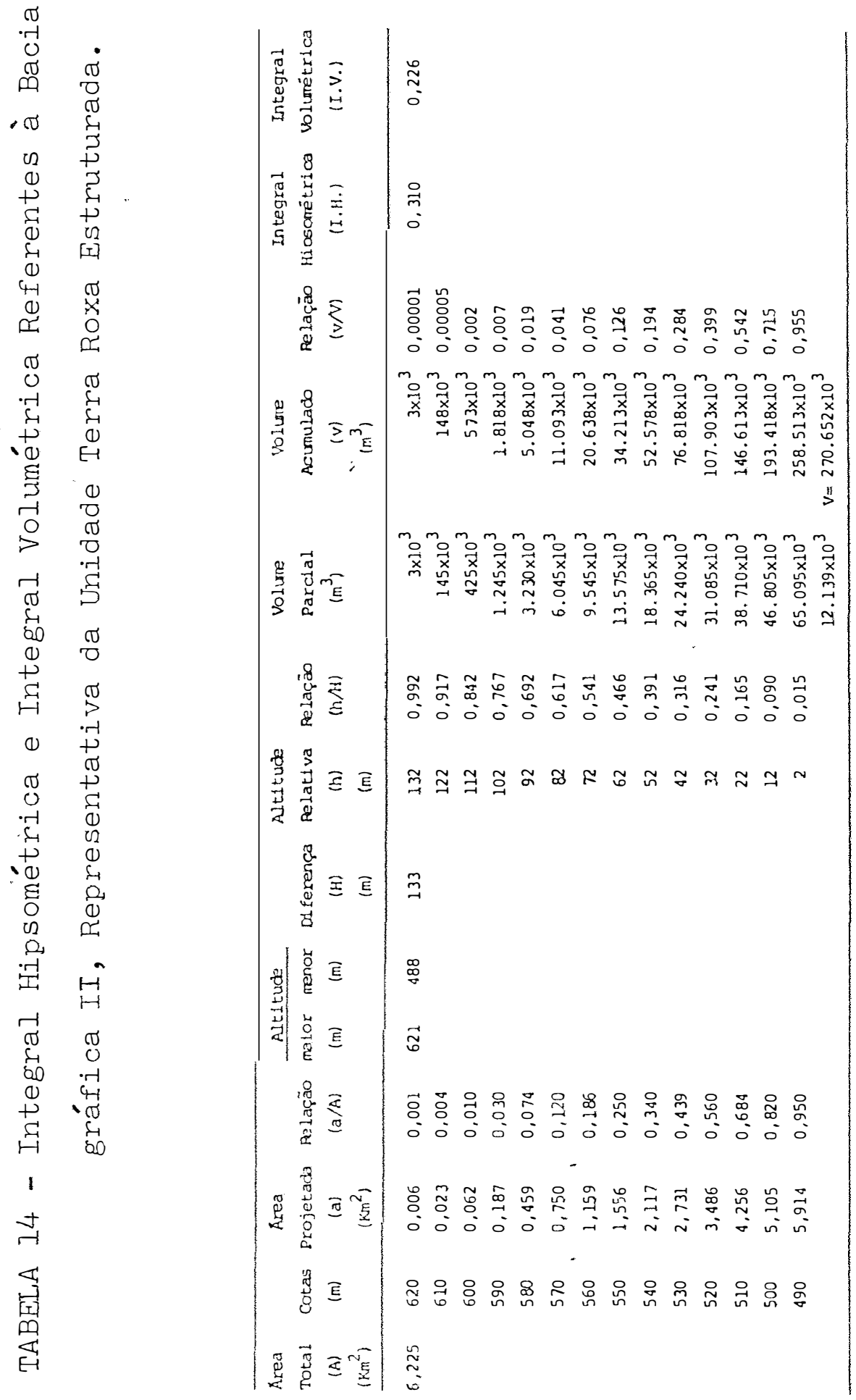




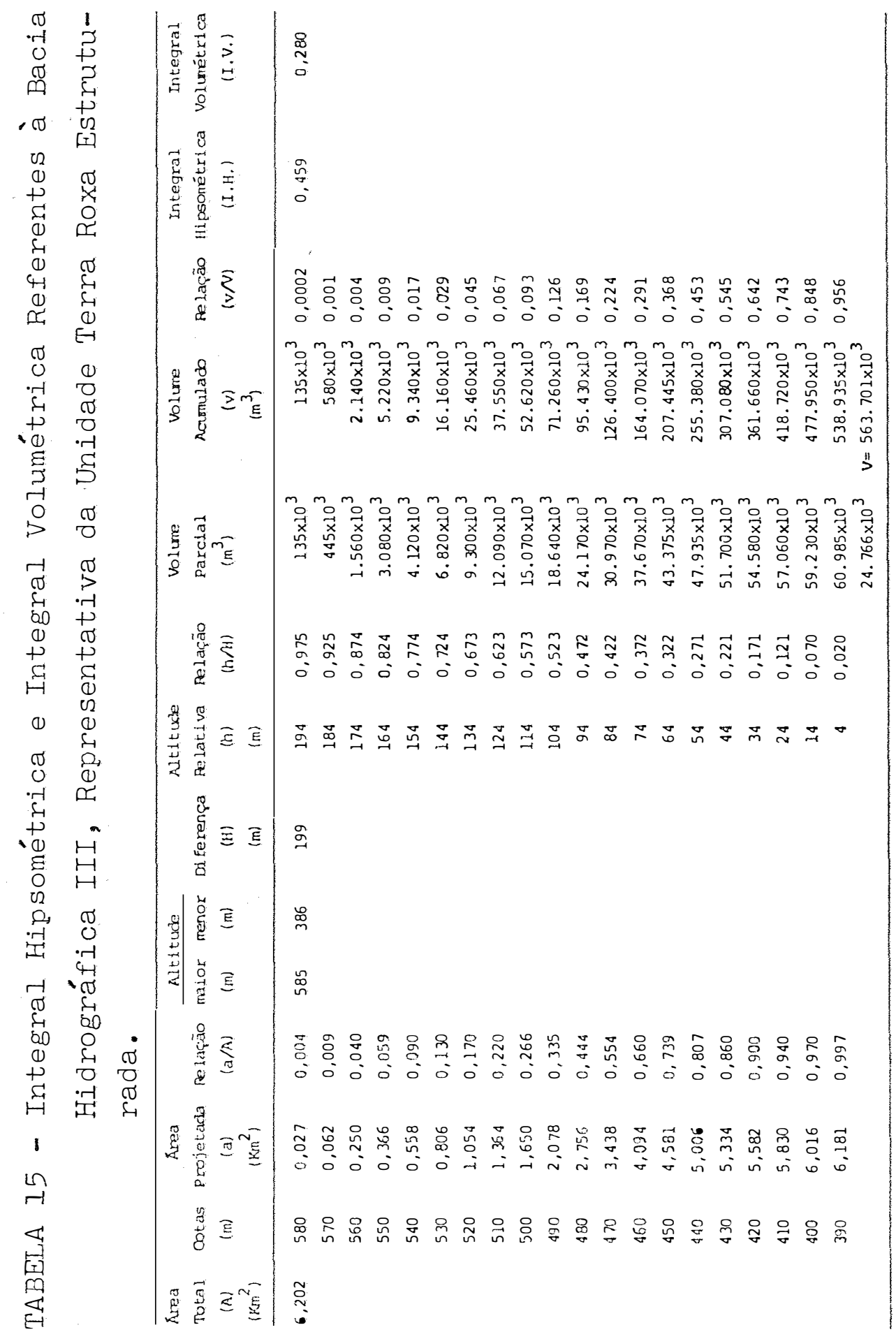




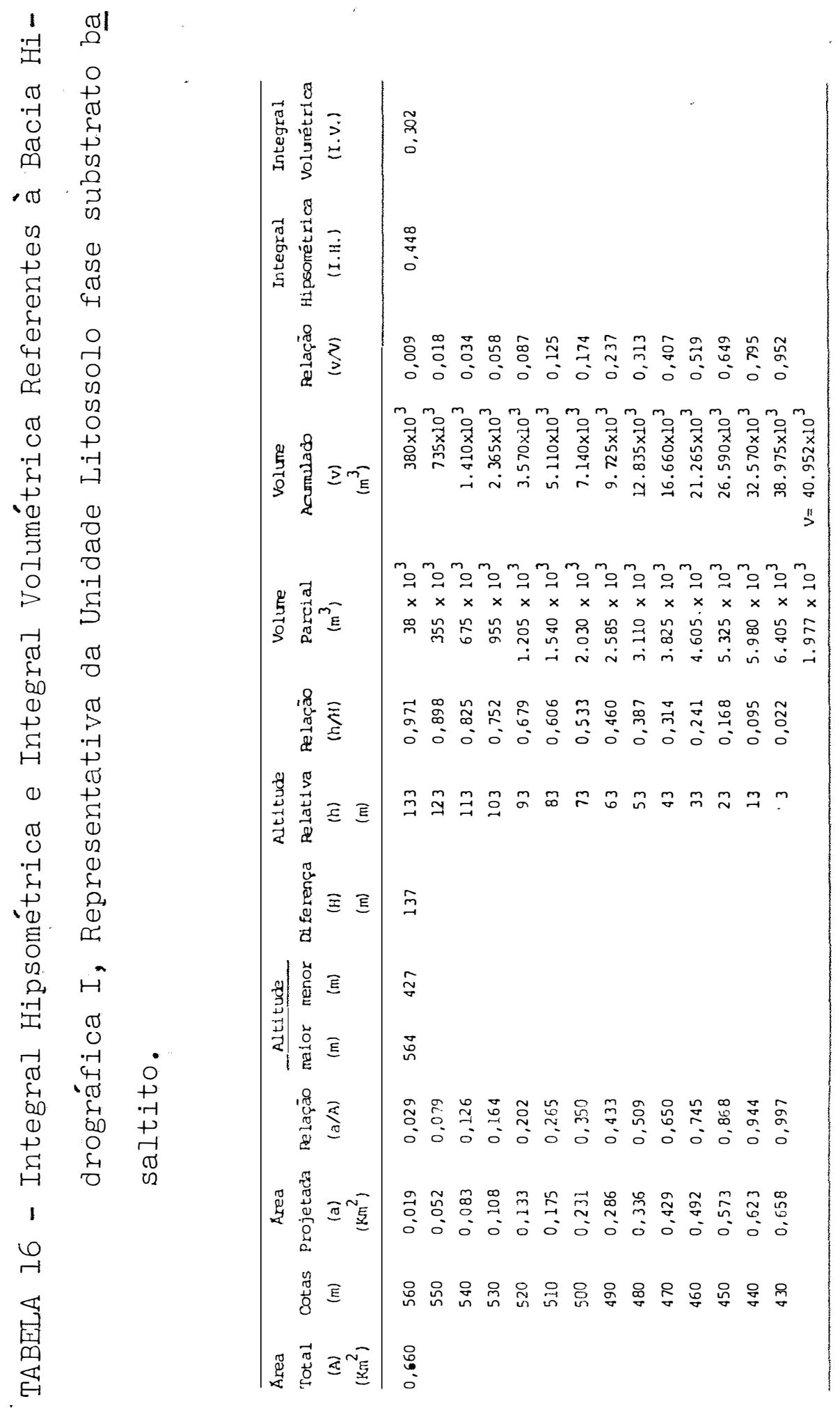




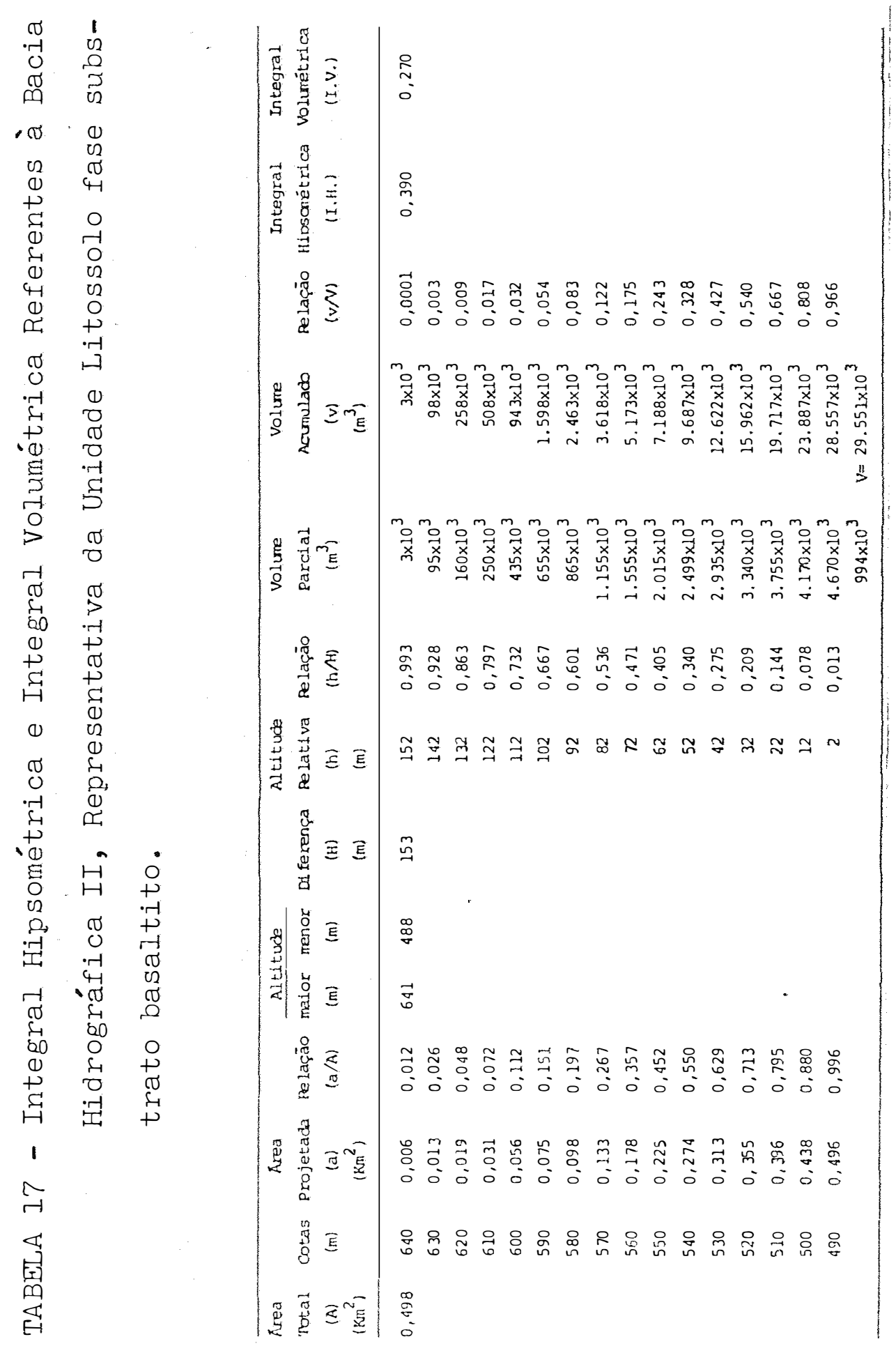




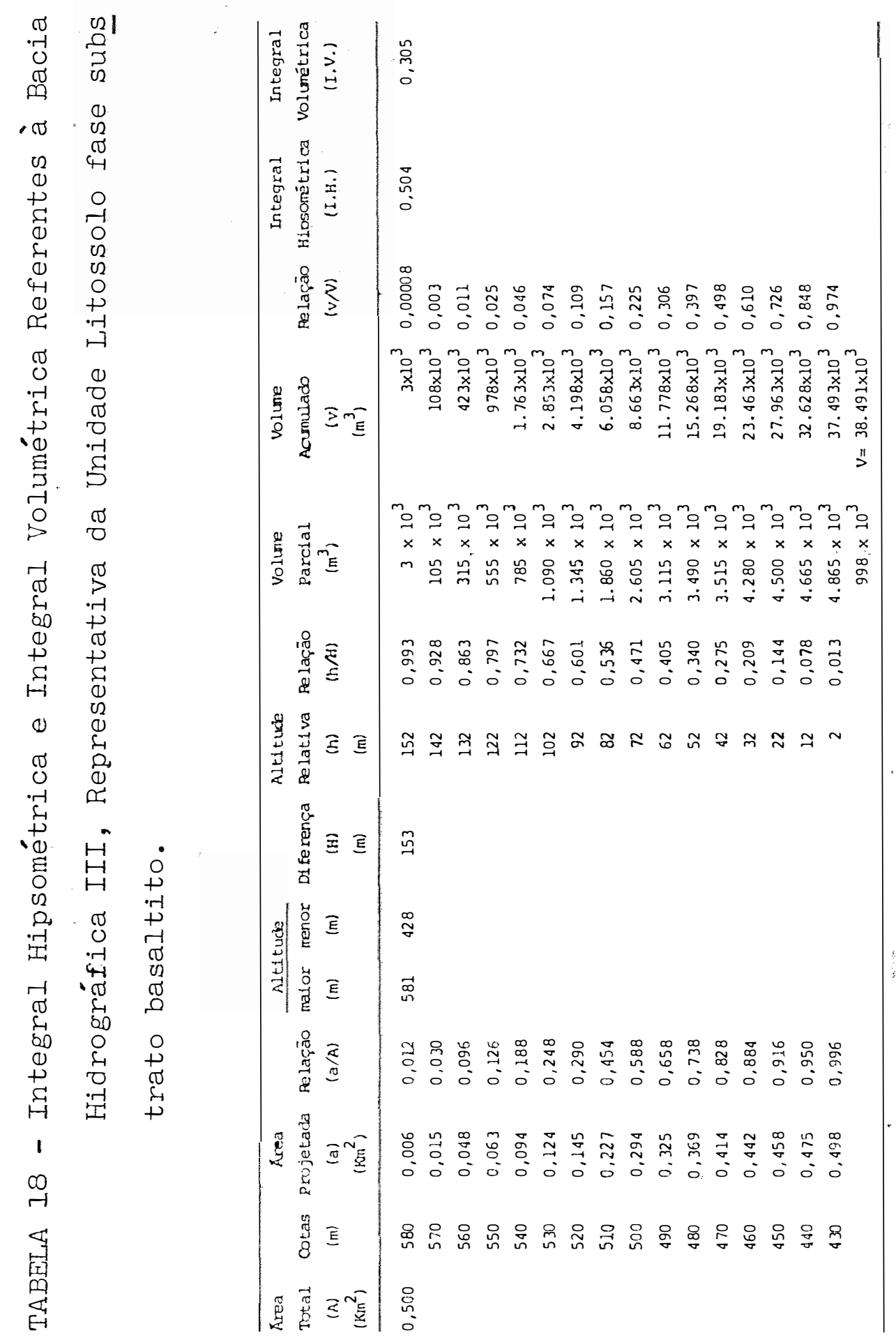




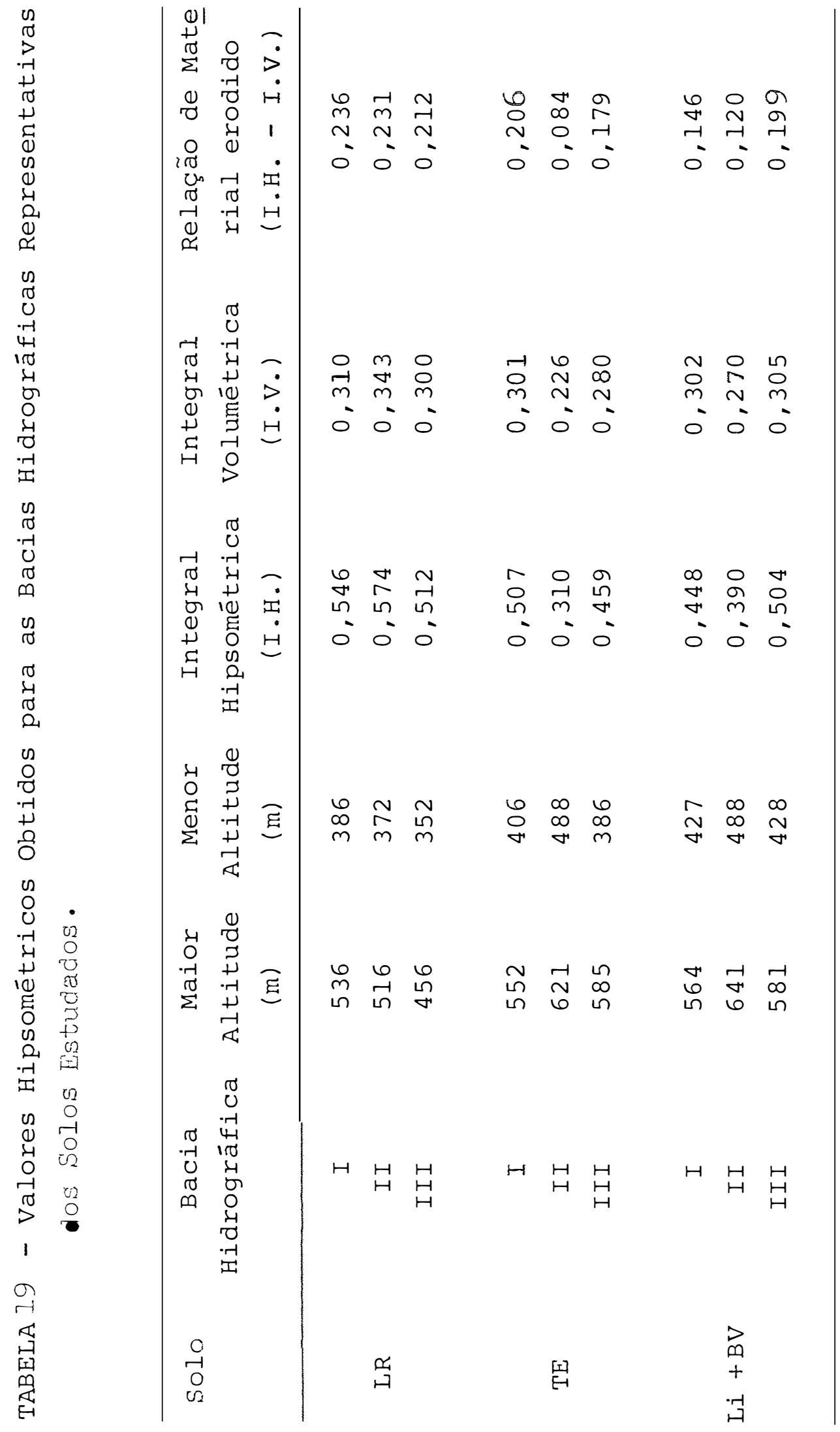




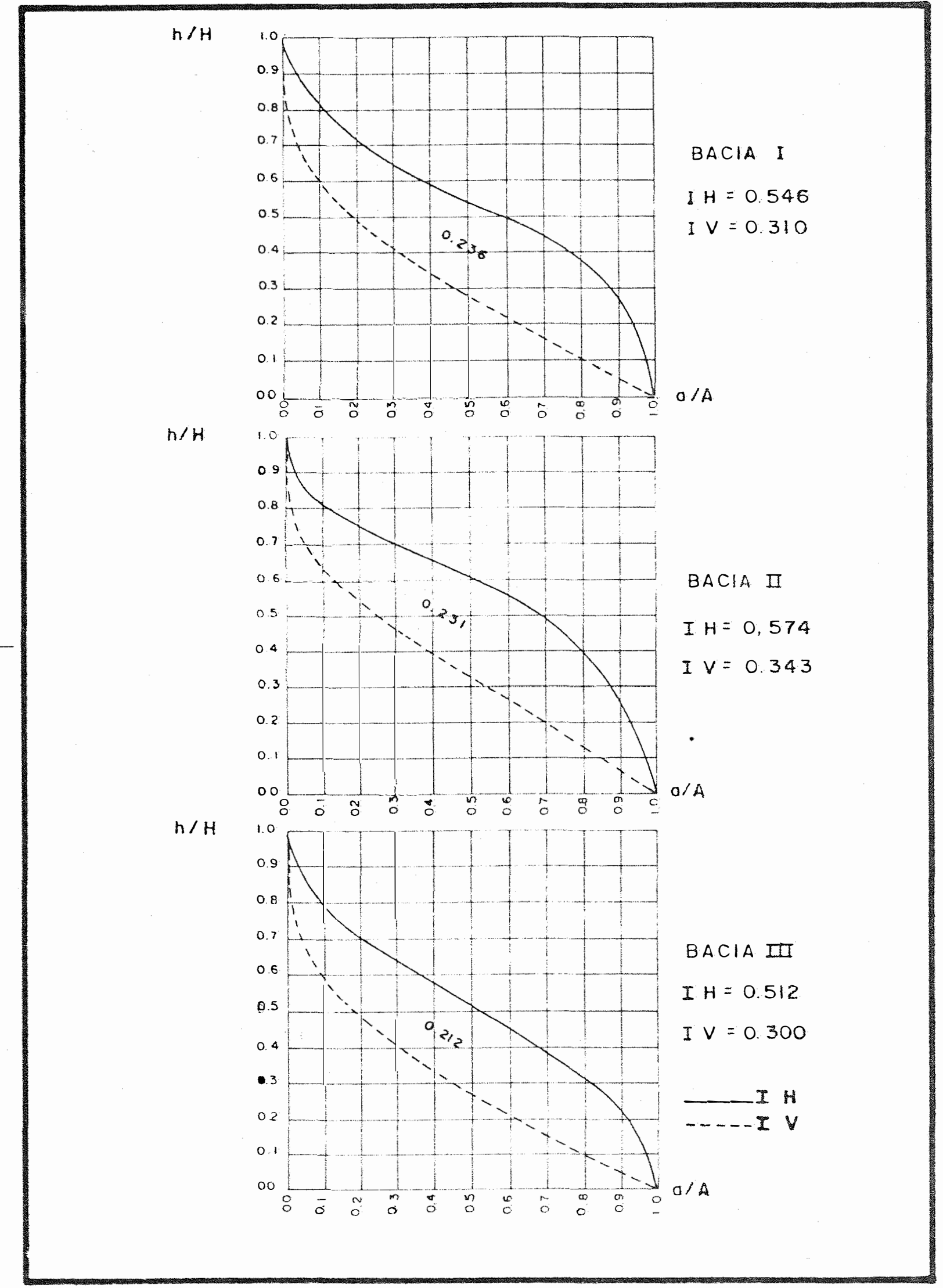

Fig. Il Integrais Hipsométricos e Volumétricos Representativas do Unidode Lotossolo Roxo. 


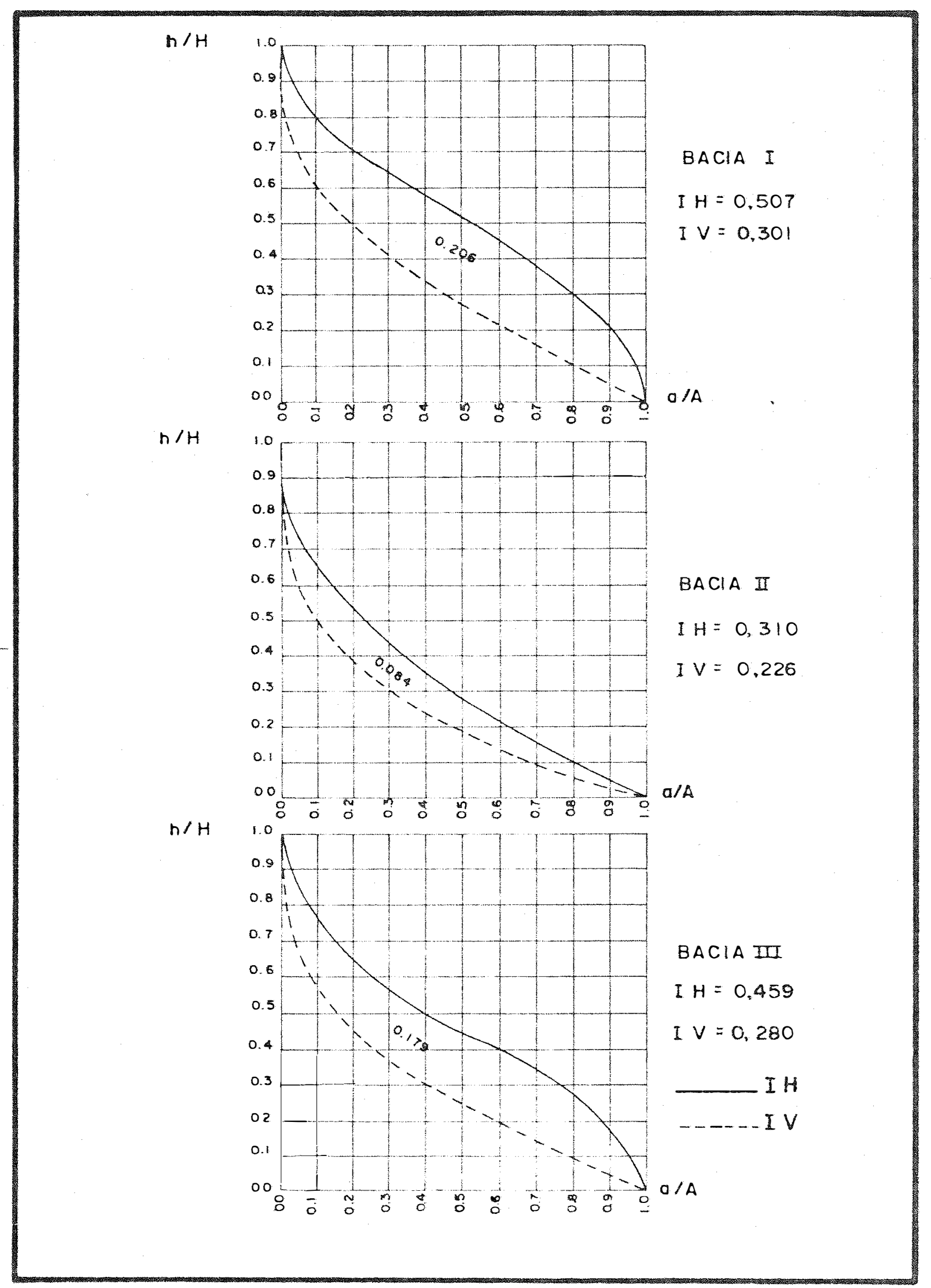

Fig. 12 Integrois Hipsométricos e Volumétricas Representotivos do Unidade Terro Roxo Estrufurodo. 


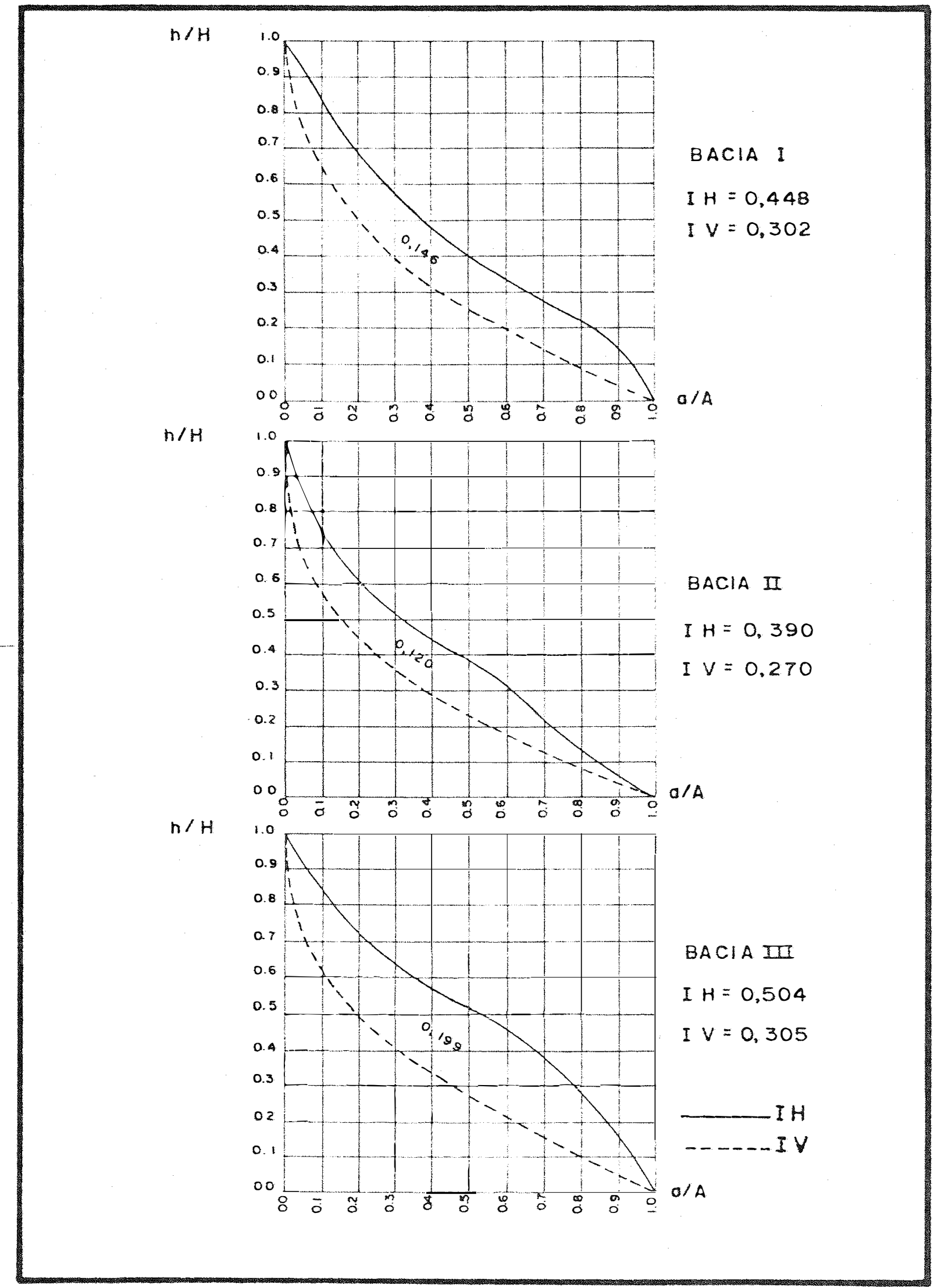

Fig. 13 Integrais Hipsométricas e Volumétricos Representativas do Unidade Litossolo fase substrato bosaltito. 


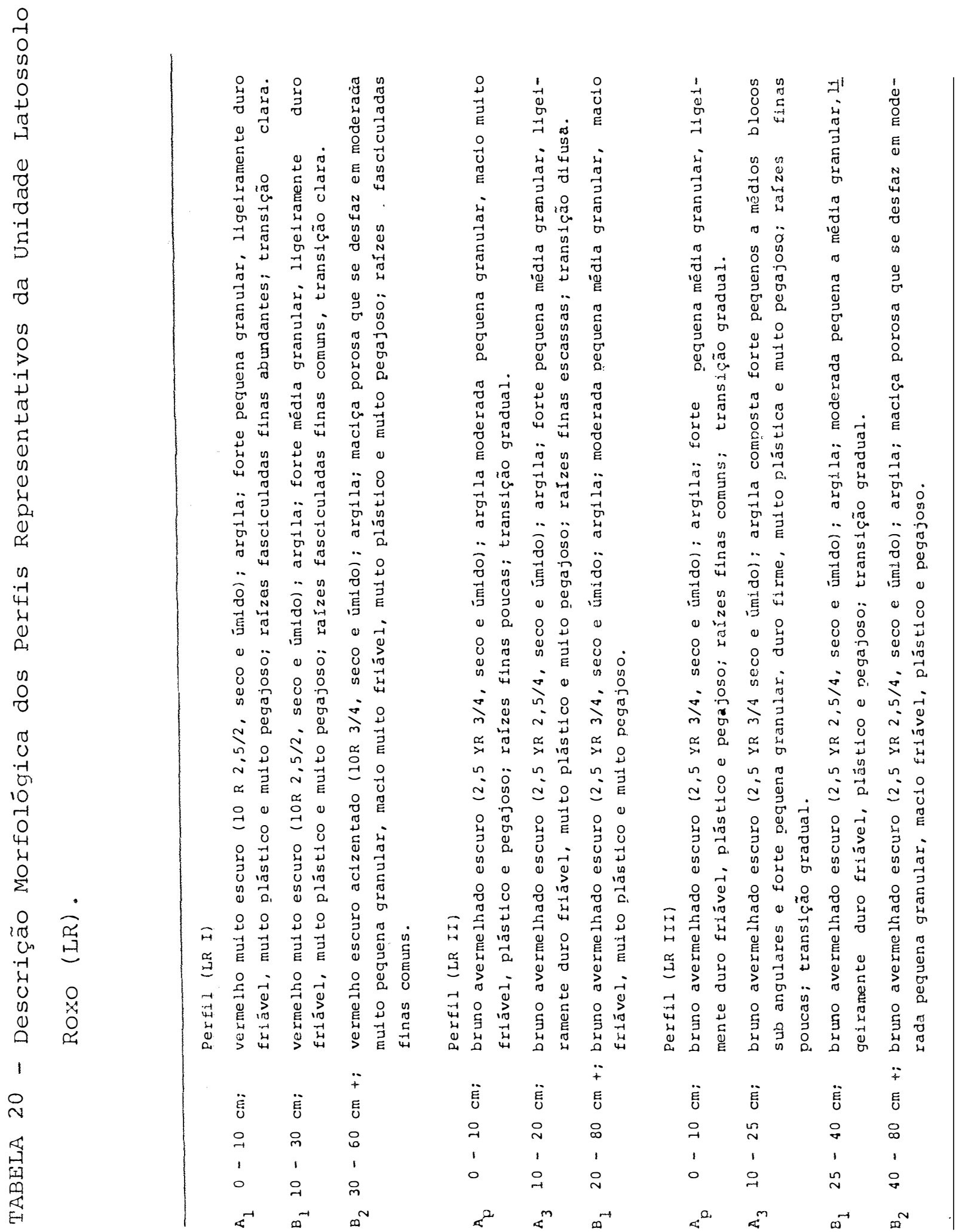




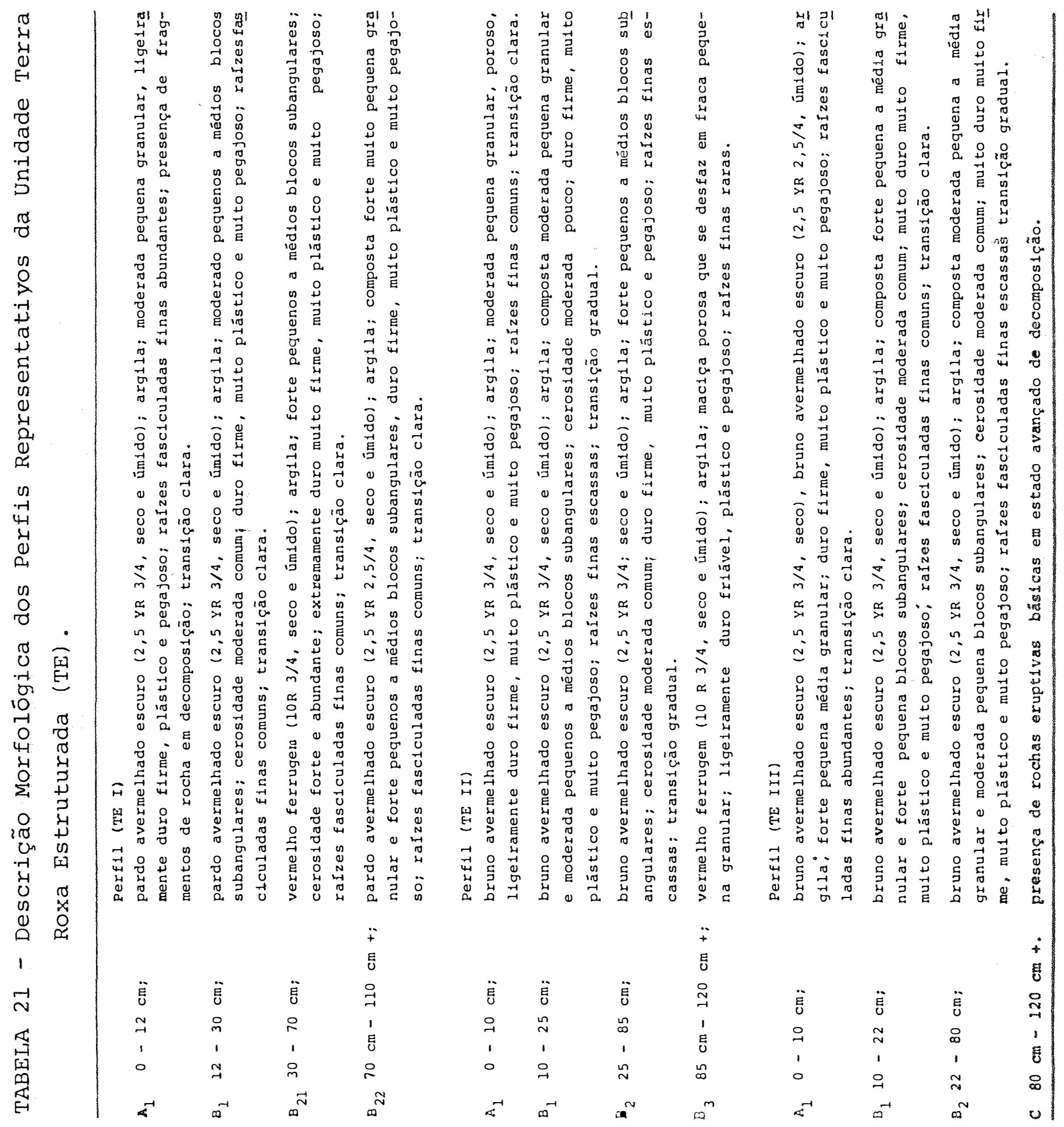




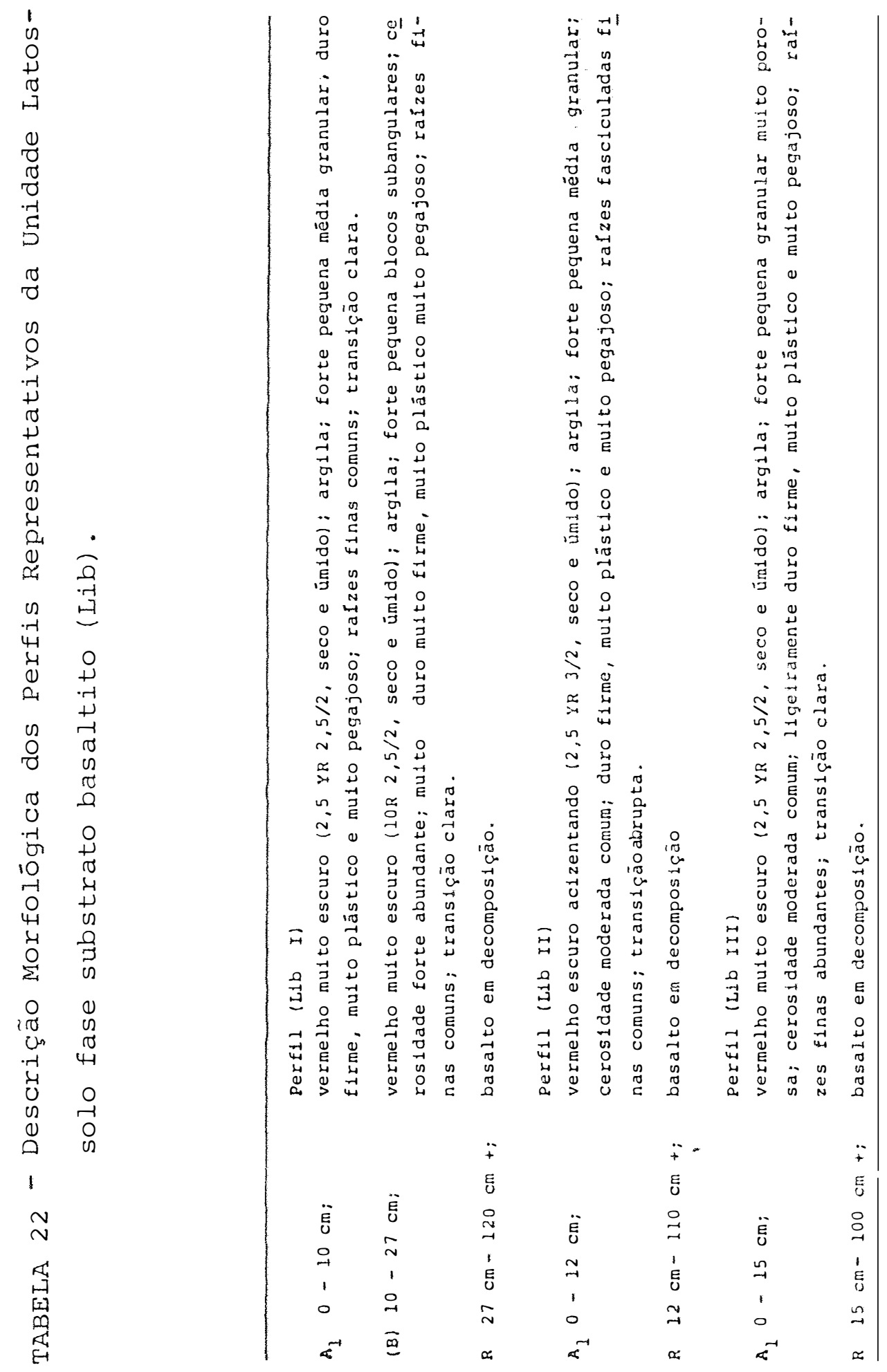




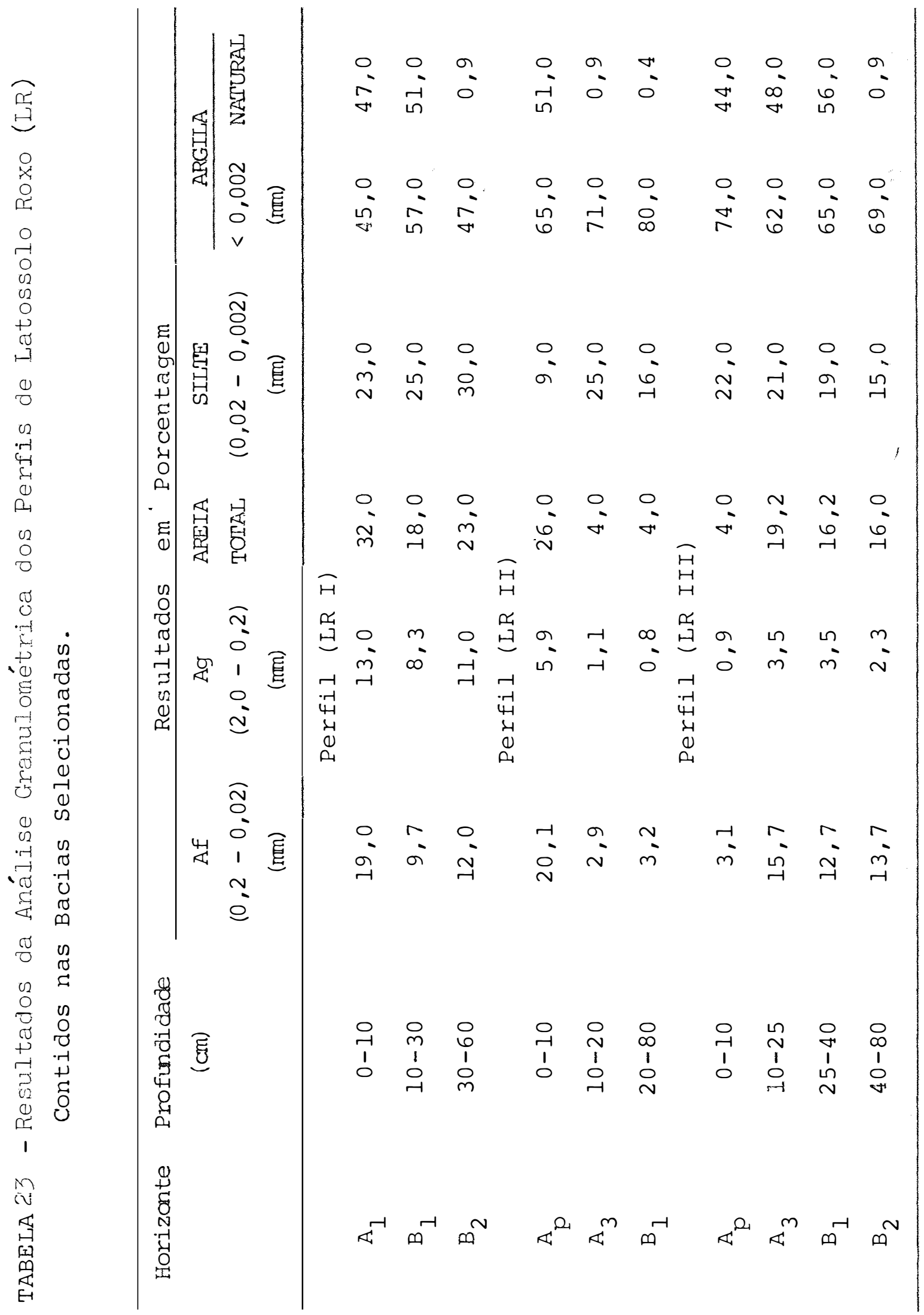




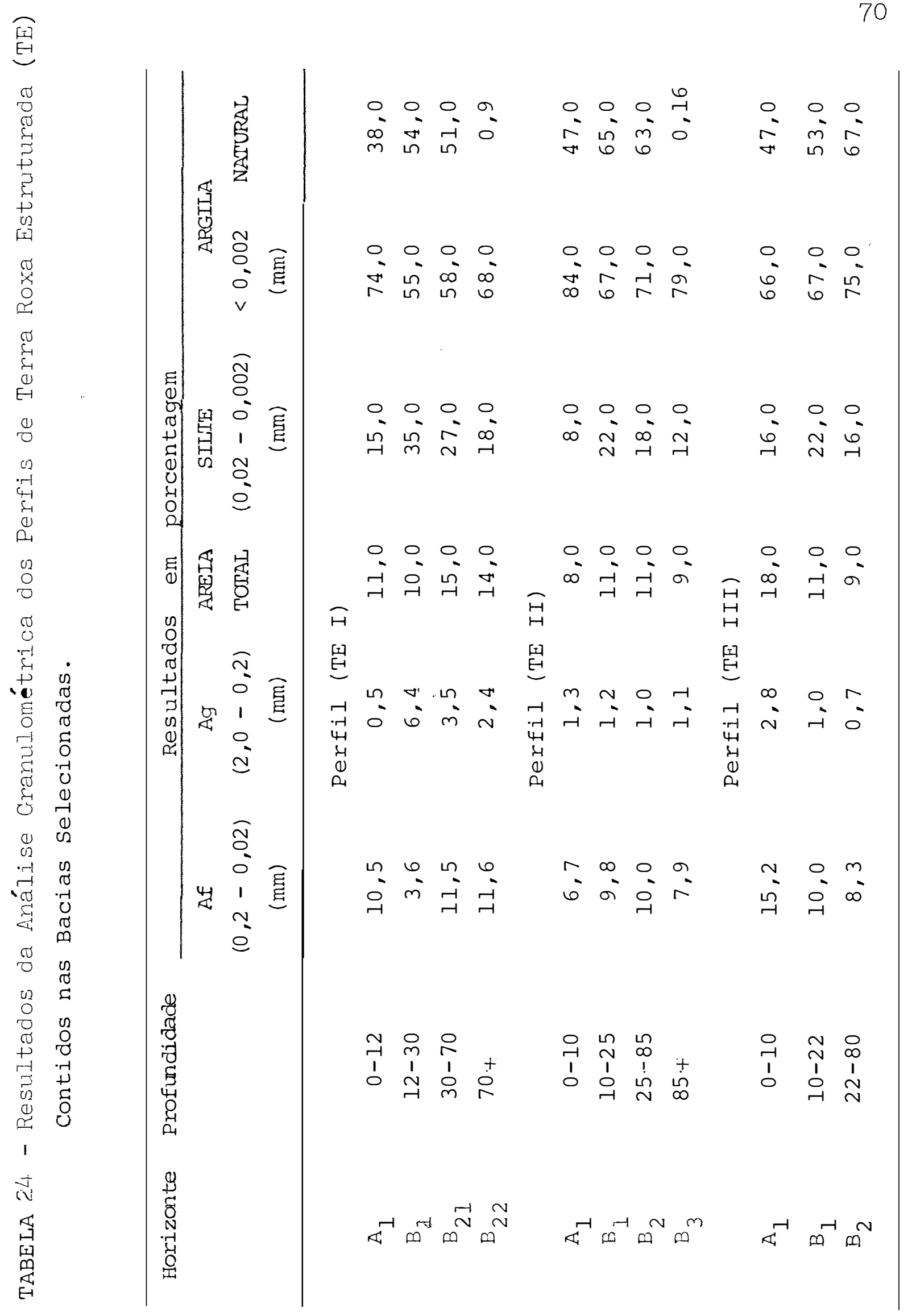



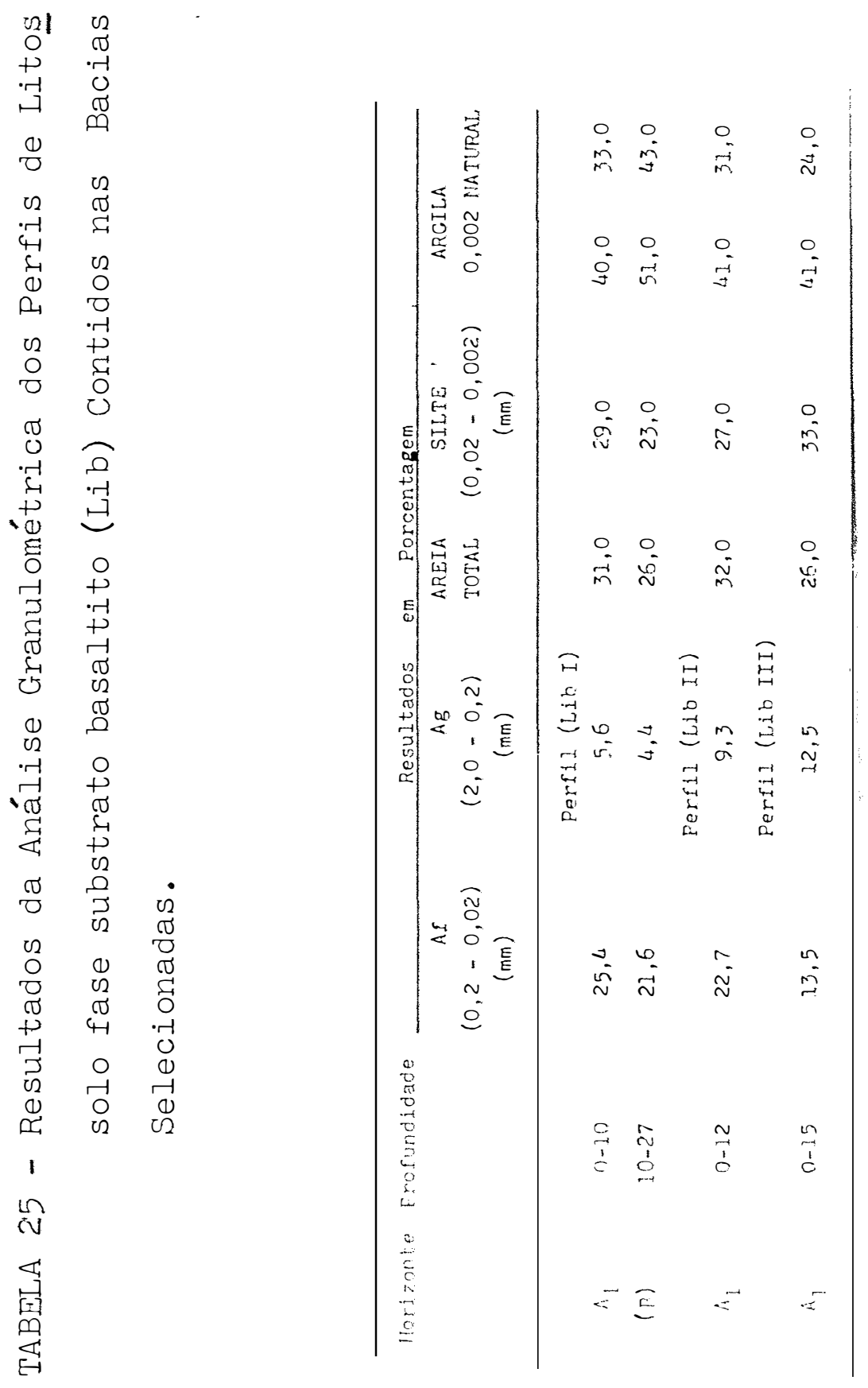


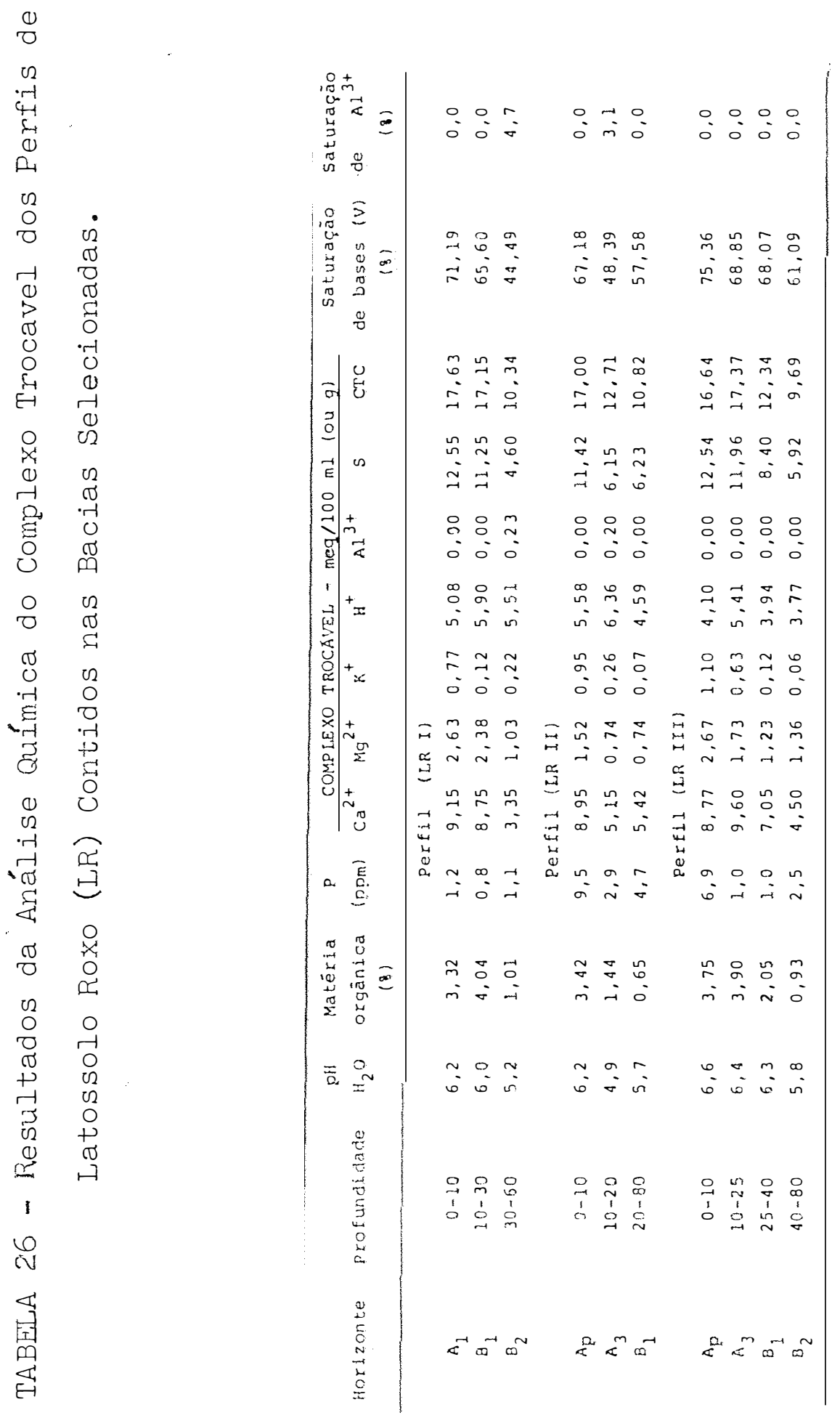




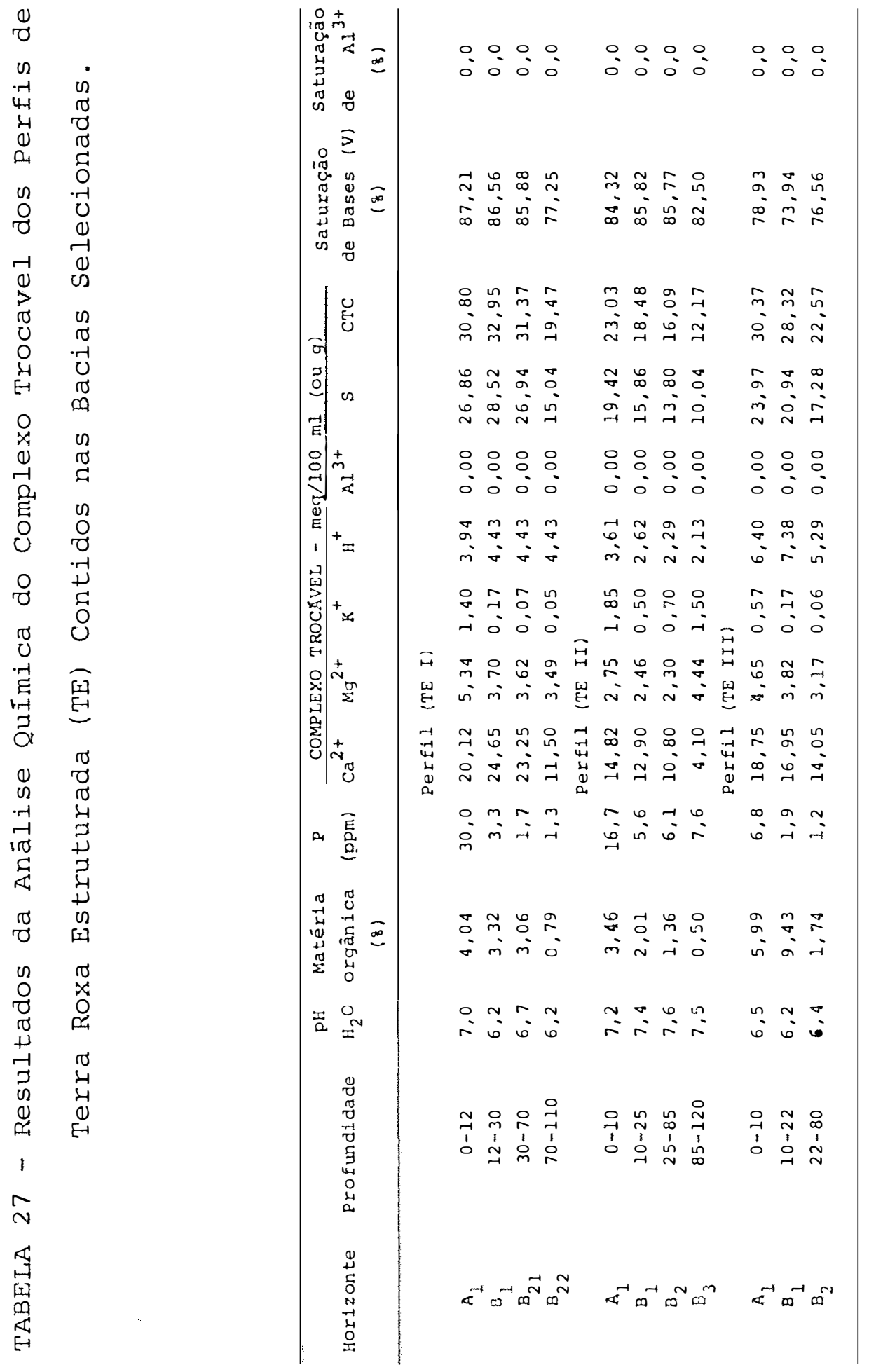




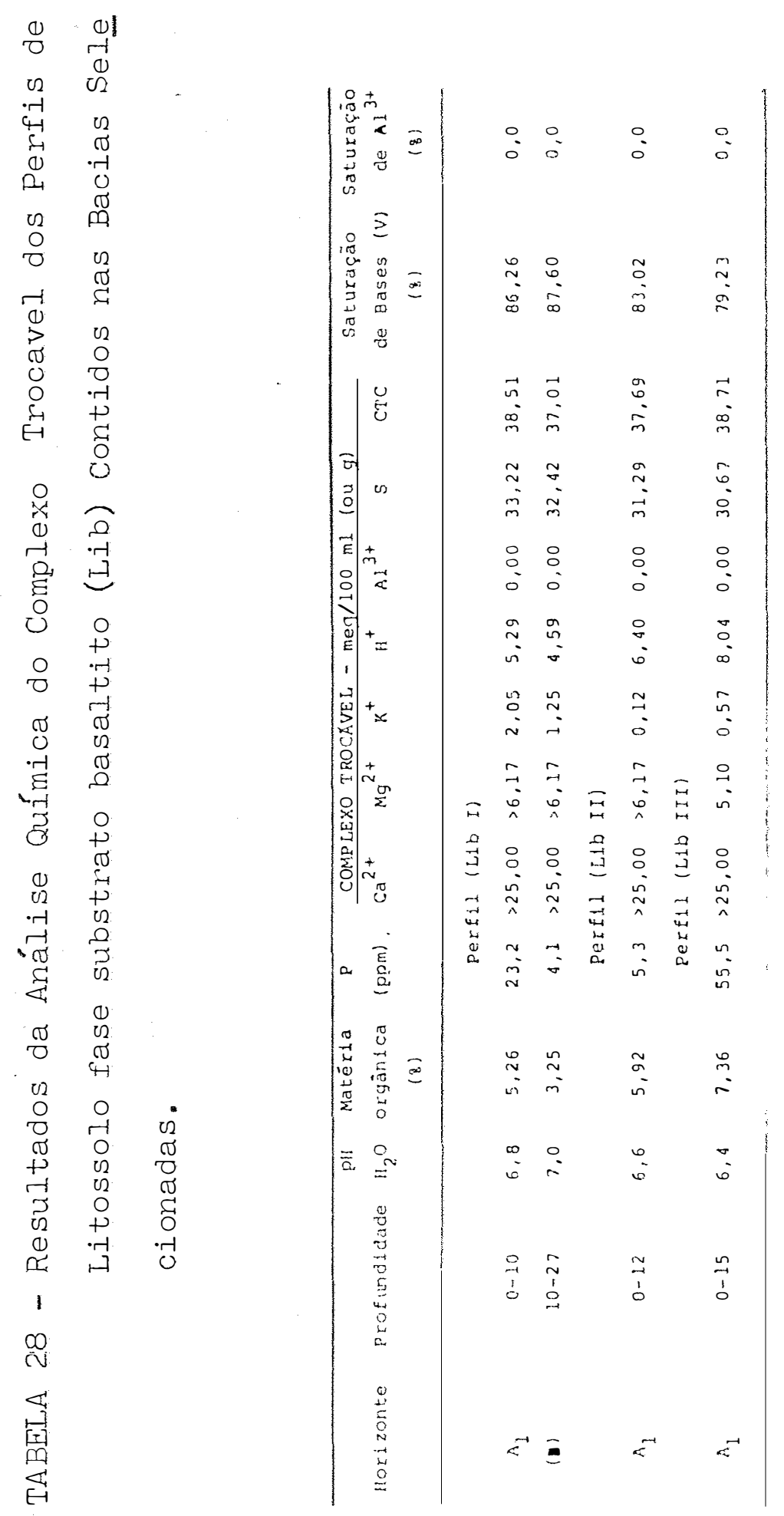


5. DISCUSSÃO DOS RESULTADOS

\subsection{Dados Climáticos}

Os dados climáticos da região mostram que a precipitação é consideravelmente maior que a evapotranspiração diferença de $398 \mathrm{~mm}$, provavelmente ocasionando deflúvio que pode causar erosão, quando encontrar condições propícias.

A temperatura média anual é de $21,50 \mathrm{C}$ e 0 valor da precipitação total é de $1554 \mathrm{~mm}$, sendo que os meses de maior precipitação são novembro e dezembro e os de menor precipitação são julho e agosto, conforme Tabela 2 .

A evapotranspiração potencial é de $1156 \mathrm{~mm}$ e o armazenamento tem alteração negativa no mês de agosto e excesso no ano todo, exceto em agosto e setembro. A deficiência anual assume o valor de $5 \mathrm{~mm}$ e o excedente anual, o valor de $403 \mathrm{~mm}$

A partir desses dados foi calculado, o Balanço Hídrico, representado na Figura z, onde se visualizami melhor os períodos de excedente e deficiência hídrica. 
5.2. Características das Bacias Hìdrográficas

A rede de drenagem da área estudada, decalcada de fotos aéreas, contendo as bacias hidrográficas de 3 a ordem de ramificação escolhidas para representar cada uridade de so Jo, Figura 3, mostra diferenças na permeabilidade e ná relação entre infiltração e deflúvio entre as unidades de solo.

\subsubsection{Análise dimensional e semelharça geométrica}

O estudo de similaridace geométrica de bacias hidrográficas permite agrupar bacias semelhantes independente mente de diferenças de tamanho. O teste de semelhançe geométrị ca propõe que se comparem as bacias relacionando-as duas a cuas através dos parâmetros contidos na Tabela $l_{4}$, obtendo-se para os valores lineares uma média aritmética que, elevada à sua razão de escala quadrática, pode ser comparada com a razão en tre áreas. Quanto mais semelhantes foren as bacias, menores de verão ser as suas diferenças de razões quadráticas.

A aplicação do teste permitiu maior confiabili dade ra escolha das bacias hidrográficas contidas na mesma unidade de solo.

As maiores bacias estudadas pertencem à unidade Latossolo Roxo e estão situadas em relevo plano a suavemen te ondulado, sendo que as representativas da unidade Terra Ro xa Estruturada têm em média, aproximadamente, a metade da á- 
rea das bacias de Latossolo Roxo; $6,57 \mathrm{~km}^{2}$ em relação a 12,33 $\mathrm{km}^{2}$, conforme se code observar na Tabela 3 , têm drenagem mais rica e apresentam -se em relevo ondulado, enquanto que as bacias representativás dos Solos Litólicos apresenta uma área mé dia, 12 vezes maior do que a da unidade Latossolo Roxo ( 0,55 para $12,33 \mathrm{~m}^{2}$ ) e estão em relevo ondulado a fortemente ondulado, conforme a Tabela 3.

Embora a área seja uma característica que dife rencie as três unidades, através de seus valores decrescentes do Latcssolo Roxo para os Solos litólicos, Tabela 5, com o nú merc de segmentos de rios e o comprimento total da rede, analisados isoladamente, essa proporoionalidade não ocorre.

o comprimerto total de segmentos de rios não possibilita uma diferenciação entre as uniclades Latossolo Roxo e Terra Roxa Estruturada, embora sejam geneticamente diferentes; concordando com observações feitas por CARVAIFio (1977).

5.2.2. Características do pacrão de drencigem

Os parâmetros que definem o padrão de drenagem das bacias hidrográficas (frequência de rios, densidade de drẹ nagem, razão de textura e razão de textura média), relacionados com o material subjacente (rochas ou solos) foram estudados por vários autores, dentre os quais: HORTON (1945), SMITH (1950), LUEDER (1959), RAY e FISCHER (1960), RAY (1963), RICCI e PEIRI (1965), que obtiveram conclusões muito gerai.s sobre os fatores responsaveis pelo desenvolvimerito das redes de dre 
nagem, tais como: a permeabilidade, a resistência à erosão e a relação entre infiltração e deflúvio. Esse fato, provavelmen te, esteja correlacionado com a escolha de bacias de ordem elevada para a obtenção dos resultados, o que deve ter acarretado a inclusão de solos ou rochas heterogêneos na amostragem. FRANÇA (1968), MARCHE'TII (1969), SOUZA (1975)e CARVALHO (1977), dentre outros, trabalharam com solos a nível de série e com bacias hidrográficas pequerias, terdo concluído que, nessas condições, os Índices se mostraram consistentes e refletiram a influência do fator solo no deservolvimento das redes de drenagem.

Os resultados obtidos no presente trabalho con cordam com os autores acima citacios, como pode ser visualiza do através da Tabela 6 e da síntese apresentada na Tabela 7 .

Os solos com B latossólico apresentam valores menores de densiciade de drenagem do que os solos com B textural. O valor da densidade de drenagem encontrado para o latọ solo Roxo $(0,89)$ está em conformidade com os obtidos porERAN ÇA (1968) e ESPINDOLA e GARCIA (1978), aresentando, no entan to, valor menor do que c encontrado por GEVAERD (1976). Para a 'Terra Roxa Estruturada o valor foi de 1,92; embora maior do que o obtido para o Iatossolo Roxo, é bem menor do que o en contrado por GEVAERD. (1976), não se assemelharido ao encontra do gor CARVALHO (1977), o que provavelmente deve ser atribuido à variação do relevo de ocorrêrrcia desse solo. Para a uni- 
dade Solos Litólicos o valor da densidade de drenagem foi de 6,25 que é superior ao encontrado para o Litossolo fase substrato argilito - folhelho, MARCHETTI (1969). Provavelmente,es se alto valor da densidade de drenagern se deva ao relevo em que esses solos ocorrem (ondulado e mortanhoso) e à sua peque na profundidade, bem como à estrutura de rocha subjacente, que permite um deflúvio maior do que a infiltração.

Embora o número total de segmentos de rios, isoladamente, não tenha mostrado significância para a distinção entre os solos estudados, quardo relacionado à área das bacias mostra evidências de diferentes comportamentos hidrológicos.

A frequêrcia de rios, no Latossolo Roxo (0,92), está de acordo com os valores encortrados por FRAICGA (1968), GEVAERD (1976) e ESPINDCLA e GARCIA (1978). Pará a Terra Roxa Estruturada, o valor da frequência de rios (4,1I) é mito semelhante ao obtido por GEVAPR (1976) e é bem superior ao encontrado por CARVALHO (1977), pelo mesmo motivo apresentado pa ra a densidade de drenagem.

A unidade Solos Litólicos apresentou a maior valor de frequência de rios $(31,46)$, refletindo nitidamente $\underline{u}$ ma infiltração dificultada pelo relevo e pela proximidade da superfície do material de origem.

A razão de textura média, também, apresentou a rnesma tendência da densidade de drenagem e da frequência de rios, aumentando seu valor da unidade Latossolo Roxo para a 
do Litossolo fase substrato basaltito.

A classe de textura topográfica foi classifica da como grosseira para a área de ocorrência do Latossolo Roxo e média para a Terra Roxa Estruturada e Litossolo fase substra do basaltito, não distinguindo o comportamento hidrológico des tas duas últimas unidades. A razão disso pode ter sido a inclusão de Brunizem Avermelhado na área de ocorrência da unida de Litossolo fase substrato basaltito.

Através da Tabela 7, podem ser visualizados os valores médios dos parâmetros do padrão de drenagem, mostrando que existe uma nítida diferença entre os valores obtidos para cada uma das unidades de solo. Pode-se observar que os coeficientes de variação obtidos para os valores médios dos pa râmetros estudados foram, de modo geral, menores para a unida de Latossolo Roxo. Esse fato, talvez, esteja ligado ao relevo de ocorrência desse solo (plano a suavemente ondulado), o que proporciona uma melhor amostragem, pois, possui menor erro de escala na fotografia aérea.

os parâmetros do padrão de drenagem foram estu彑 dados comparativamente, através de correlações entre frequência de rios e densidade de drenagem, textura e densidade de drenagem e, textura e frequência de rios.

Para os parâmetros correlacionados, ajustaramse equações de retas, e examinando-se a Tabela 8, pode-se notar que para a correlação entre frequência e densidade de dre nagem foram constatados valores do teste $F$, para a regressão 
do teste t para inclinação da reta, valores significativos a nível de 1\%; enquanto que, para a correlação entre razão de textura e densidade de drenagem e, textura e frequência de rios, as equações foram ajustadas a nível de 5\%. Esses resul tados mostram uma inter-dependência entre os parâmetros estu dados por refletirem o comportamento hidrológico dos solos.

\subsection{Características do Relevo.}

\subsubsection{Razão de relevo}

Tha região que está sob um mesmo clima e tem o mesmo material de origem, tem as variações de solo comandadas pelo relevo. Em relevos suavemente ondulados, ocorrem normal mente, solos maduros (bem desenvolvidos); enquanto que, em solos mais jovens ocorrem relevos fortemente ondulados.

Os mapas de drenagem, com curvas de nível de 10 em 10 metros, representados nas Figuras de 4 a 10, mostram, através da equidistância horizontal e das inflexões das curvas de nível, o traçado da rede de drenagem, assim como as seguintes classes de relevo: relevo suavemente ondulado, pa ra a região dominada pelos latossolos; ondulado para Terra Roxa Estruturada e, ondulado a fortemente ondulado, para os solos menos desenvolvidos.

Para a interpretação e comparação do relevo das diferentes áreas, foram agrupados, na Tabela 9, os valores de altitude, amplitude altimétrica, maior comprimento da 
bacia (rampa máxima) e razão de relevo.

o Índice razão de relevo, que representa a re lação entre a amplitude altimétrica e o maior comprimento das bacias, permite comparar a altimetria das unidades, mostrando que, quanto maiores forem esses valores, mais acidentadoé o relevo, como é o caso da unidade onde predominam os Litossolos fase substrato basaltito, que possuem os maiores valores de razão de relevo.

Apesar dos valores da Amplitude Altimétricaes tarem bem próximos e não permitirem qualquer diferenciação , sendo muito variaveis dentro de cada unidade, a razão de relevo separa e distingue o relevo das unidades, já que leva em conta o comprimento das bacias.

A razão de relevo encontrada para a unidade Latossolo Roxo variou de 0,0264 a 0,0272, para a unidade Terra Roxa Estruturada a variação foi de 0,0384 a 0,0440, e pa-ra a unidade Litossolo fase substrato basaltito, de 0,0867 a 0,1214 .

Desse modo, a razão média de relevo da região dos Latossolos é 1,5 vezes menor do que a da região da Terra Roxa Estruturada, e 4 , $O$ vezes menor do que a da região de $\mathrm{L}$ i tossolo fase substrato basaltito; enquanto que a da região de Terra Roxa Estruturada é 2,6 vezes menor que a de I.itossolo fase substrato basaltito, mostrando a diferenciação do relevo de ocorrência desses solos. De certa forma, essa razão re flete a relação entre infiltração e deflúvio, mostrando iden 
tidade com os valores médios de densidade e drenagem, frequência de rios e razão de textura (Tabela 6).

CARVALHO (1981) encontrou, para os Latossolos, uma razão de relevo da ordem de 0,047 e para os Solos Litólicos, 0,1234. Para os Litossolos fase substrato basaltito houve concordância de resultados com os obtidos neste traba Iho, embora isso não tenha ocorrido para os Latossolos, o que provavelmente se deve à variação do relevo de ocorrência desses solos, que normalmente é suavemente ondulado a ondulado.

5.3.2. Integrais hipsométricas e volumétricas

O relevo, segundo RANZANI (1963), refere-se às desigualdades de forma da superficie do solo e que pode ser identificado em termos de diferenças de altitude.

Segundo esse autor, o relevo pode ser desmembrado em seus elementos: tipo, classe e declive para melhor caracterizar os solos presentes em uma determinada área.

Ảs desigualdades da superfície resultam verten tes que, segundo PENTEADO (1978), apresentam formas convexas e côncavas, com ou sem segmentos retilíneos.

o relevo, comandando a relação entre infiltra ção e deflúvio, interfere de modo significativo na evolução de um solo, da mesma maneira que o tipo de solo influi, simultaneamente, na evolução do relevo.

Numa tentativa de sanar essa dificuldade (STRAH 
LER, 1952), propôs a obtenção da Integral Hipsométrica através de relações de áreas $(a / A)$ e de altitudes $(h / H)$ para se inferir sobre a maneira pela qual a massa está distribuída dentro de uma bacia de drenagem, desde a sua maior até a sua menor altitude.

A Integral Hipsométrica permite comparar bacias hidrográficas de áreas e relevos diferentes, desde que sejam de mesma ordem de ramificação e inferir sobre a remocão de materiais das bacias através de drenagem, a.ssim como comparar estágios evolutivos de bacias de diferentes regiões.

De acordo com VIEIRA (1978), a integral hipso métrica expressa o material existente antes do início do pro cesso de erosão, considerando-se o perímetro atual das bacias; enquanto que a integral volumétrica expressa o que restou. A diferença entre as duas representa o material que foi retira do pela erosão, tomando-se por base o rio de terceira ordem de ramificação.

Nas Tabelas 10 a 18 estão os cálculos realiza dos para a obtenção das integrais e estão reunidos, na Tabela 19, os valores hipsométricos de maior interesse para a in terọretação.

A.s integrais hipsométricas referentes ao Lato tossolo Roxo (Figura 1l), ocupam posições centrais do diagra ma e o valor médio da integral hipsométrica $(0,544)$, juntamente com a sua posição no diagrama, é indicativo segundo STRAHLER (1957) do estágio de maturidade do relevo. 
A forma da curva da integral hipsométrica, no caso do Latossolo Roxo, apresenta-se mais cavada nas cabecei ras e abaulada no terço inferior do diagrama, indicando que - material erodido permanece dentro da bacia, o que provavel mente se deva ao relevo suavemente ondulado com declives lon gos.

A Figura 12 apresenta as integrais hipsométri cas e volumétricas das bacias representativas de Terra Roxa Estruturada, cujos valores das integrais hipsométricas são 0,507, 0,310 e 0,459, respectivamente, para as bacias I, II e III, sendo o valor médio de 0,425. O relevo das bacias de Terra Roxa Estruturada vai de suavemente ondulado a ondulado, sendo que as bacias I e III apresentam um relevo mais suave; enquanto que a bacia II apresenta um relevo mais acidentado, o que confere à integral hipsométrica um valor menor.

A representação da curva no diagrama e o valor da integral hipsométrica das bacias I e III, representativas da unidade Terra Roxa Estruturada, praticamente se equivalem às encontradas para a unidade Latossolo Roxo; a re fletir comparativamente o estágio de maturidade do releyo; contudo o valor médio das integrais hipsométricas é da ordem de 0,425 indicando que o relevo está num estágio de maturida de tendendo à velhice.

Observando a Tabela 19, verifica-se que as di ferenças entre as integrais hipsométricas e volumétricas resultaram um valor médio de relação de material erodido para a 
Terra Roxa Estruturada, da ordem de 0,156 e para a unidadé Latossolo Roxo, da ordem de 0,226. O menor valor encontrado para a Terra Roxa Estruturada de deve, provavelmente, à sua estrutura que the confere maior resistência à erosão, indicando que essa propriedade mostrou-se mais importante na re sitência à erosão do que o relevo, principalmente quando este não é muito contrastante.

As integrais hipsométricas e volumétricas, re ferentes à unidade Litossolo fase substrato basaltito, estão representadas na Figura 13. O valor médio das integrais hipsométricas é de 0,444 , a curva representativa está abaixo da metade do diagrama, o que, segurdo STRAHLER (1957), indica que o relevo, comparativamente com as outras unidades, estä numa fase de desenvolvimento que vai. da maturidade à velhice, embora os solos dessa unidade sejam considerados jovens, devido à remoção intensa dos mantos de alteração.

As diferentes formas das curvas observadas pa ra esta unidade não se apresentam tão uniformes quanto as re presentativas das outras unidades de solo estudadas, o que provavelmente se justifica por possível ocorrência de aflora ramentos de rocha na parte superior das bacias e/ou inclusões de solos mais desenvolvidos no terço inferior das bacias. Os volumes médios de material erodido na Terra Roxa Estruturada e do Iitossolo fase substrato basaltito são, praticamente, os mesmos: 0,156 e 0,155, respectivamente. Para a Terra Roxa Estruturada, isso reflete o relevo e a re- 
sistência ̀̀ erosão; enquanto que para o Litossolo fase substratö basaltito, reflete o relevo de ocorrência, onde a formação praticamente equivale à remoção.

\subsection{Característic Morfológicas, Granulométricas e Quími-} cas dos Solos Estudados

5.4.1. Latossolo Roxo

A unidade Latossolo Roxo, analisada através de três perfis representativos, ocorre em relevo plano a suavemente ondulado, com declives longos e pouco inclinados. São profundos, argilosos, de color çäo vermelho-arroxeado, provą velmente, heraada do material originário, que contém em sra composição minerais escuros, principalmente óxidos de ferro. Todavia, a cor avermelhada é indício da baixa hidratação dos óxidos de ferro contidos na massa do solo, devido à boa drenagem que é consequência, principalmente, da associação estrutura e relevo de ocorrência desses solos, que propicia uma boa permeabilidade e uma alta relação entre infiltração e deflúvio. A consistência, no estado seco, é ligeiramente dura; no estado úmido, friével e no estado molhado, plástica e pegajosa.

o teor de argila varia de 45 a $80 \%$ e os teores de argila natural, após 30 a $40 \mathrm{~cm}$ de profundidade, são muito baixos $(0,9 \%)$, denotando resistência à erosão.

A saturação de bases é mais èlevada até, aproximadamente, $30 \mathrm{~cm}$ de profundidade, variando de 48 a $75 \%$ 
e tendendo a diminuir com o aumento da profundidade. A capacidade de troca catiônica apresenta níveis altos, acima de $10 \mathrm{meq} / 100$ (OLEYNIK, 1980), a qual no entanto, está ocupada por quantidade considerável de ions de hidrogênio (de 3,77 a $6,36 \mathrm{meq} /(\mathrm{OOg})$, embora o cálcio seja o cátion dominarte. o pH atinge valores de 4,9; contudo, os níveis de alumínio são baixos, inieriores a $0,23 \mathrm{meq} / \mathrm{lo0g}$.

\subsubsection{Terra Roxa Estruturada}

Os perfis de Terra Roxa Estruturada são profun dos, argilosos, bem drenados, de cor arroxeada, desde brunoavermelhado escuro até pardo avermelhado escuro, com estrutu ra em blocos subangulares no horizonte $B$ e cerosidade modera da e pouca a forte e abundante. São formados a partir de rochas eruptivas básicas, situados em relevos suavemente ondulado e ondulado, com declives curtos, favorecendo o deflúvio e consequentemente, diminuindo a relação entre a infiltração e o deflúvio.

o teor de argila varia de 55,0 a 84,0\% o que Ihes confere textura argilosa; por outro lado, o incremento no teor de argila natural, de 10 a $70 \mathrm{~cm}$ de profundidade, in dica o processo de eluviação e iluviação que ocorreu ao longo do tempo, dando formação a um horizonte $\mathbf{z}$ textural.

o Índice de saturação de bases varia de 74 a 87\%, considerados de nível bom a alto, por OLEYNIK (1960). Des sa forma, os solos podem ser classificados como eutróficos. A 
capacidade de troca catiônica é alta, superior à encontradana unidade Iatossolo Roxo, assumindo valores de 12, 17 a 32,95, o que, provavelmente, deve ser atribuído ao teor de matéria orgânica. O cátion predominante é o cálcio que ocupa a maior parte da CTC. O pH tem valores que variam de 6,2 a 7,8, indicando uma reação fracamente ácida a alcalina.

\subsubsection{Litossolo fase substrato basaltito}

A unidade Litossolo fase substrato basaltito posiciona-se em relevo fortemente ondulado a montanhoso. São rasos, apresentando, em média, $15 \mathrm{~cm}$ de profundidade e sendo pouco intemperizados, frequentemente com fragmentos de basaI to alterado. O relevo de ocorrência favorece o escoamento su perficial e, consequentemente, há um diminuição na relação en tre infiltração e deflúvio, o que acarreta a formação de maior número de sulcos, proporcionalmente à área das bacias. Os perfis estudados são argilosos, de colora ção vermelho muito escuro e vermelho escuro acinzentado, com estrutura forte, pequena a média, granular, a forte, pequena, granular, muito porosa e com pouca profundidade que, associa da ao relevo, facilita o processo de erosão. Apresentam cero sidade moderada e comum a forte e abundante. Quando ocorre ho rizonte (B) incipiente, a consistência é dura, firme, muito plástico e muito pegajoso.

A saturação de bases é muito elevada (de 79 a 
87\%). A capacidade de troca de cátions, também, assume níveis altos (de 37,01 a 38,71 meq/lo0g) e os cátios dominantes são o cálcio e o magnésio, que ocupam quase $80 \%$ das posições da capacidade de troca cationica, o pH, (de 6,4 a 7,0) revela acidez fraca.

Numa anáIise comparativa entre as unidades de solos, Tabelas 23,24 e 25 , pode-se notar que a porcentagem de areia fina dos Litossolos fase substrato basaltito é superior à encontrada na Terra Roxa Estruturada, a qual, por sua vez, é superior à do Latossolo Roxo. A porcentagem de a gila, nos perfis como um todo, é maior na Terra Roxa Estrutu rada do que nas duas outras unidades.

As análises moffológica, química e granulométrica dos perfis estudados, provenientes do mesmo material o riginário (eruptivas básicas), permite estabelecer as seguin tes comparações:

A profundidade dos solos diminui na seguinte sequência: $\mathrm{LR}>\mathrm{TE}>\mathrm{Lib}$.

A areia fina encontrada foi quase sempre supe rior à areia grossa e essa diferença (areia fina - areia gros sa) tende a diminuir na sequência: $\mathrm{Lib}>\mathrm{TE}>\mathrm{LR}$.

O teor de silte é maior na unidade Litossolo fase substrato basaltito, quando comparada à porcentagem que ocorre no Latossolo Roxo e na Terra Roxa Estruturada.

Os níveis de $\mathrm{Ca}^{+2}$ e de $\mathrm{Mg}^{+2}$ diminuem, enquanto que aumenta proporcionalmente o nível de $\mathrm{H}^{+}$na sequência 
Lib, TE, LR e, consequentemente, a soma de bases aumenta do LR para o Iib. A capacidade de troca catiônica e a saturação de bases são maiores no Litossolo fase substrato basaltito, diminuindo na unidade Latossolo Roxo, provavelmente devido à presença de argila de maior atividade naqueles solos e: ao teor crescente dessa fraçäo, na sequência Li.b, LR, TE.

Essas diferenças marcantes entre as unidades de solo, atribuidas às diferentes relaçöes entre infiltração e deflúvio, propiciam distinguir estágios de desenvolvimento dos solos, sendo mais avançado para o Latossolo Roxo, seguido da Terra Roxa Estruturada e do Litossolo fase substrato ba saltito. 
6. CONCLUSÕES

A metodologia utilizada e os dados obtidos no presente trabalho permitiram as seguintes conclusões:

a) a frequência de rios, a densidade de drena gem, a razão de textura e a razão de textu ra média mostrarammse eficientes na distin ção entre os solos, apresentando valores de crescentes ha seguinte sequência: LitossoIo fase substrato basaltito $>$ Terra Roxa Estruturada > Latossolo Roxo;

b) A classe de textura topográfica não permitiu a distinção entre Terra Roxa Estrutura da e Litossolo fase substrato basaltito;

c) A razão de relevo foi significativa para indicar diferenças de drenagem entre as unidades de solo, sendo seus valores decres centes na seguinte sequência: Litossolo fa 
se substrato basaltito $>$ Terra Roxa Estru turada $>$ Latossolo Roxo;

d) A descrição morfológica e as análises químicas e granulométricas dos solos, associa das à analise hipsométrica, permitem afírmar que os solos encontram-se num estágio de evolução que obedece à sequência: Latos solo Roxo > Terra Roxa Estruturada > Litossolo fase substrato basaltito; enquanto que o relevo da unidade Latossolo Roxo encontra-se num estágio de maturidade em comparação às unidades Terra Roxa Estruturada e Litossolo fase substrato basaltito que se encontram num estágio de maturidade tendendo para a velhice. 
7. BIBLIOGRAFIA CITADA

BELCHER, D. J., 1942. The Engineering Significance of Soil Patterns. Photogramm Engng., Washington, II (2:):115-1148.

BRASIL. Ministério da Agricultura. Serviço Nacional de Pesquisa Agronômica, 1960. Levantamento de Reconhecimento dos Solos do Estado de São Paulo. Rio de Janeiro, 605 p. (Boletim $n \cong 12)$.

BRASIL. Ministério da Agricultura. Divisão de Pesquisa Pedológica, 1971. Levantamento de Reconhecimento dos Solos do Nordeste do Estado do Paraná. Curitiba, Paraná, 151 p. (BO Ietim Técnico no 16).

BURINGH, P., 1960. The Applications of Aerial Photographs in Soil Surverys. In: Manual of Hhotographic Interpretation. Am. Soc. of Photogramm. Chap. 11, Appendix A, p. 633 - 666. 
CARVALHO, W. A., 1977. Fotointerpretação de Bacias Hidrográficas de Amostras Circulares de Redes de Drenagem de Solos com Horizonte B Textural. Piracicaba, ESALQ/USP, I26 p. (Tese de Doutoramento).

CARVAIHO, W. A., 1981. Relações entre Relevo e Solos da Bacia do Rio Capivara - Município de Botucatu, S.P., Botuca tu, FCA/UNESP (Tese para obtenção do título de Livre - Dô cente).

CARVALHO, W. A.; PIEDADE, G.C.R.; ANDRADE, F.C., 1983. Interação Solo - Relevo - Material Erodido em Pequenas Bacias de drenagem no Município de Botucatu. R. bras. Ci.Solo,7: $83-87$.

CHORLEY, R.J. e MORLEY, L.S.D., 1959. A Simplified Approxima tion for the Hipsometric Integral. In: Jour. of Geol.vol. $\underline{67}: 566-71$

COLWELL, R.N., 1952. Photographic interpretation for civil puposes. In: AMERICAN SOCIETY OF PHOTOGRAMNIETRY. Manual of Photo grammetry. Washington, p. 535 - 602.

DEPARTAMENTO DE GEOGRAFIA E COLONIZAÇÃO - Divisão de Geogra fia, 1963, Folha Topográfica SF-2̌-V-I-2, Escala 1:50000.

DEPARTAMENTO DE GEOGRAFIA TERRA E COLONIZAÇÃo - Divisão de Geografia, 1970, Folha Topográfica SF - 22 - V - II - I, Escala 1:50000. 
EMPRESA BRASILEIRA DE PESQUISA AGROPECUARIA, 1979. Manual de, Métodos de Analise de Solo. Rio de Janeiro. 235 p.

ESPINDOLA, C. R., 1977. Relação entre os Solos e Elementos da Paisagem na Zona do Baixo Rio do Peixe (região Conchas nhembi, SP). Piracicaba, ESALQ/USP, 113 p. (Dissertação de Nestrado) .

ESPINDOLA, C. R. e GAIHEGO, H. R., 1979. Os solos com B latos sólico e com B textural das regiões intertropicais úmidas.

FADEL, H., 1972. Fotointerpretação de Bacias de Rede de Drena gem em Três Séries de Solos da Fazenda Ipanema, Município de Araçoiaba da Serra (SP). Piracicaba, ESALQ/USP, 92 p. (Dissertação de Mestrado).

FRANÇA, G. V. de, 1968. Interpretação Fotográfica de Bacias e de Redes de Drenagem Aplicada a Sojos da Região de Pira cicaba, ESALQ/USP, 151 p. (Tese de Doutoramento).

FRENZEI, A., 1980. Medidas preventivas contra os processos e rosivos. In: Simoósio sobre o Controle de Erosão. Curitiba, 201 a 213, março. 
FROST, R. E. et alii., 1960. Photointerpretation of soi.ls. In : Manual of photographie inter retation." Washington, Am. Soc. of Photogramm. Chap. 5, p. $343-402$.

GAMBLE, E. E. e DANIELS, R. B., 1964. Parent Material of Upper and Middle - Costal Plain soils in North Carolina. Soil Sci. Soc.Amer. Proc., Madison, 38: 633 - 37.

GEVAERD, I., 1976. Identificação dos Fatores Determinantes das Características Placo-hipsométricas de Três Unidades de SoIo da Região Nordeste Paranaense. Piracicaba, ESALQ/USP,63p (Tese de Doutoramento).

GOOSEN, D., 1968. Interpretation de Fotos Aereas y su Importancia en Levantamiento de Suelos. Roma, Organizacion de las Naciones Unidas para la Agricultura y la Alimentacion. 58p. (Boletim sobre Suelos no 6).

GREENE, H., 1945. Classification anduse of tropical soils. Soil. Sci. Soc. Amer. Proc., 10 : $392-5$.

HORTON, R. E., 1945. Erosional Development of Streams and their Drainage Basins: Hidrophysical Approach to Quantitative Morphology. In: Bul. Geol. Soc. Amer. 56 : $275-370$. 
HOWE, R. H. L., 1960. The application of aerialphotographic interpretation to the investigation of hidrological problems. Photogramm. Engng., Washington, 26 : $85-95$.

KILMER, V. I. e ALEXANDER, L. T. 1949. Method of making mechanical analysis of soils. Soil Sci., New Brunswick, 68: $15-26$.

LUEDER, D. R., 1959. Aerial Photographic Interpretation: Principles and Apjilications. N. York,Mc Graw, $162 \mathrm{p}$.

MAACK, R. 1953. Mapa Geológico do Estado do Paraná. Paraná, Escala: 1:750.000.

MAACK, R. 1968. Geografia Física do Estado do Paraná, 350p. Banco do Desenvolvimento do Paraná, UFP - Inst. de Biolo. e Pesq. Tecnol., Curitiba.

MARCHETTI, D. A. B., 1969. Fotointerpretação de Atributos do Relevo Aplicada a Solos da Região de Piracicaba. Piracica ba, ESALQ/USP, $58 \mathrm{p}$. (Tese de Doutoramento).

MARCOS, Z. Z. e KINJO, T., 1967. Litossol: suas característi cas e provável gênese. Anais Esc. Sup. Agric. "Luiz de Queiroz", Piracicaba, 24 : $343-52$. 
OLEYNIK, J., 1980. Manual de Fertilização e Correção dos Solos. Curitiba, ACARPA. $90 \mathrm{p}$.

PENTEADO, M. M., 1968. Geomorfologia do Setor Centro - Ocidental da Depressão Periférica Paulista. Rio Claro, Fac. Fil. Ciências e Letras, 86 p. (Tese de Doutoramento).

PENTEADO, M. M., 1974. Fundamentos de Geomorfologia. Biblio teca Geográfia Brasileira, série D, Publicação no 3, Fun dação IBGE, Rio de Janeiro, 163 p.

PIEDADE, G. C. R., 1980. Evolução de voçorocas em bacias hi drográficas do Município de Botucatu, SP. Botucatu, FCA/ UNESP, (Tese para obtenção do título de Livre-Docente).

RABBEN, E. L.; CHALMERS JÚNIOR, E. L.; MANLEY, E•; PICKNP, J. 1960. Fundamentals of photointerpretation. In: Manual. of Photographic interpretation. Washington, Am. Soc. of Photogram., Chap. 3, p. $99-168$.

RANZANI, G. 1969 b. Manual de levantamento de solos. Edgar BIducher e Editora da USP, 2'ä ed. $167 \mathrm{p}$.

RAY, R. G. e FISCHER, W. A., 1960. Quantitative Photography a Geological Research Tool. Photogramm. Engng.2. Washing ton, $26: 143-150$. 
RAY, R. G., 1963. Fotografias Aéreas na Interoretação e Mapeameñto Geológico. Trad. Jésuino Felícíssimo Jr. Inst. Geogr. Geöl. São Pauío, $88 \mathrm{p}$.

RICCI, M. e PETRI, S., 1965. Princípios dada Aerofotogrametria e Interpretação Geológica. São Paulo, Cia. Editora Nacional. $226 \mathrm{p}$.

ROBINSON, G. H.; DEVEREAUX, R. E.; OBENSHAIN, S.S., 1961. Soil of Virginia. Soil Sci., 92 : $129-42$.

RUELLAN, A., 1971. Contribution a la connaissance de solsces regimes mediterrneennes (Marroc Oriental). Memories O.R. S. T. O.M. n 9 54. Patis. $302 \mathrm{p}$.

SCHUNM, S. A., 1956. Evolution of Drainage Systems and Slopes in Badlands at Ferth Amboy $\mathbb{N}$. Jersey. In : Bul. Geol.Soc. Amer., $67: 597-646$.

SNITH, K. G., 1950. Standards for grading texture of erosional topography. Amer. Jour. Sci., New Haven, 248 : 655 - 68 .

SOUZA, M. L. de P., 1975. Fotointerpretação das Redes de Drenagem de Três Solos com Horizonte B Latossólico Ocorrentes no Município de Ponta Grossa - Pr. Piracicaba, ESALQ/USP , 135 p. (Dissertação de Mestrado). 
STRAHLER, A. N., 1952. Hypsometric (área - altitude) analysis of erosional topography. Buli. Geol. Soc. Amer., Colorado, 63: $1117-41$.

STRAHLER, A. N., 1957. Quantitativa Analysis of Watershed Geo morphology. Trans. Am. Geophys. Union, New Haven, 38: 91320 .

SUNMERSON, C.H., 1954. A philosophy for photointerpreters. Pho togramm. Engng., Washingtor, 20 : 396 - 397.

TERCINIER, G. e QUANTIN, P., 1968. Influence de l'alterátion de cenches set ponces volconiques d'age récent sur la natü ra les propriétes et la fertilité de sols aux Nouvelles Híbrides. Cah. ORSTOM, Sér. Pedol 6 : 203-24.

THORNTWAITE, C. W. e J. R. MATHER, 1955. The Water Balance. Climatology. Centerton, N. J. $\underline{8}$ (I) : 104.

U. S. DEPARTAMENT AGRICULTURE, 1951. Soil Survey Manual. Wash ington D. C. 503 p. (Agr. Handbook n 18).

VAN WAMBEK, A. R. 1962. Criteria for classifying tropical soils by age. J. Soil. Sci., 13 : $124-32$.

VAN WAMBEK, A. R. 1967. Recent developments in the classification of the soils of the tropics. Soil Sci.,104:309-13. 
VASQUES FILHO, J., 1972. Critérios Morfométricos Aplicados à Fotointerpretação de Redes de Dreñagem em Três Unidades dé Solos no Município de Piracicäba. Piracicaba, ESAL,/ USP, $113 \mathrm{p}$. (Tese de Doutoramento).

VIEIRA, N. M., 1978. Estudo Geomorfológico das Voçorocas de Franca (SP). Franca, 255 p. (Tese de Doutoramento).

ZINKE, J. P. 1960. Photointerpretation in Hidrology and Wa tershed Management. In : Manual of photographic interpretation. Am. Soc. of Photogram. p. 539 - 560. 